\title{
Systemic inflammation in cardiac surgery : causes and clinical significance
}

Citation for published version (APA):

Fransen, E. J. (1999). Systemic inflammation in cardiac surgery : causes and clinical significance.

[Doctoral Thesis, Maastricht University]. Universitaire Pers Maastricht.

https://doi.org/10.26481/dis.19990409ef

Document status and date:

Published: 01/01/1999

DOI:

10.26481/dis.19990409ef

Document Version:

Publisher's PDF, also known as Version of record

\section{Please check the document version of this publication:}

- A submitted manuscript is the version of the article upon submission and before peer-review. There can be important differences between the submitted version and the official published version of record.

People interested in the research are advised to contact the author for the final version of the publication, or visit the DOI to the publisher's website.

- The final author version and the galley proof are versions of the publication after peer review.

- The final published version features the final layout of the paper including the volume, issue and page numbers.

Link to publication

\footnotetext{
General rights rights.

- You may freely distribute the URL identifying the publication in the public portal. please follow below link for the End User Agreement:

www.umlib.nl/taverne-license

Take down policy

If you believe that this document breaches copyright please contact us at:

repository@maastrichtuniversity.nl

providing details and we will investigate your claim.
}

Copyright and moral rights for the publications made accessible in the public portal are retained by the authors and/or other copyright owners and it is a condition of accessing publications that users recognise and abide by the legal requirements associated with these

- Users may download and print one copy of any publication from the public portal for the purpose of private study or research.

- You may not further distribute the material or use it for any profit-making activity or commercial gain

If the publication is distributed under the terms of Article $25 \mathrm{fa}$ of the Dutch Copyright Act, indicated by the "Taverne" license above, 
Systemic inflammation in cardiac surgery:

causes and clinical significance 
(C) E.J. Fransen, Masstricht 1999 ISBN 9052782482

Omslag: Maja Severdija

Druk: Datawyse I Universitaire Pers Maastricht 


\section{Systemic inflammation in cardiac surgery: causes and clinical significance}

\section{PROEFSCHRIFT}

ter verkrijging van de graad van doctor aan de Universiteit Maastricht, op gezag van de Rector Magnificus, Prof. dr. A.C. Nieuwenhuizen Kruseman, volgens het besluit van het College van Decanen in het openbaar te verdedigen op vrijdag 9 april 1999 om 16.00 uur door

\section{Erik Johannes Fransen}

geboren op 17 februari 1968

te Boekelo

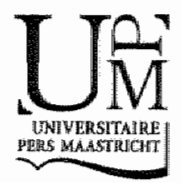




\section{Promotor:}

Prof, dr. M.J.A.P. Daemen

\section{Co-promotores:}

Dr. J.G. Maessen

Dr. W.A. Buurman

\section{Beoordelingscommissie:}

Prof. dr. G. Kootstra (voorzitter)

Prof. dr. M. van Dieijen-Visser

Prof. dr. L. Eijsman (Universiteit van Amsterdam)

Prof. dr. W. Flameng (Katholieke Universiteit Leuven, België)

Prof. dr. G.J. van der Vusse

Financial support by "Stichting Hartsvrienden RESCAR" for publication of this thesis is gratefully acknowledged. Additional support granted by AB Medical B.V., Baxter B.V., Cardio Medical B.V., COBE Laboratories Europe N.V., Jostra Medizintechnik AG, Krijnen Medical, Medtronic B.V., Sorin Biomedica Nederland N.V., TD Medical B.V., and Terumo is appreciated 
Aan mijn ouders

Voor Monique \& Milton 



\section{Contents}

\section{LIST OF ABBREVIATIONS}

CHAPTER 1. General introduction and outline of the thesis

CHAPTER 2. Systemic inflammation in patients undergoing coronary artery bypass grafting without extracorporeal circulation

CHAPTER 3. Impact of blood transfusions on inflammatory mediator release in patients undergoing cardiac surgery

CHAPTER 4. Demonstration of ischemia-reperfusion injury separate from postoperative infarction in coronary artery bypass graft patients

CHAPTER 5. Perioperative myocardial tissue injury and the release of inflammatory mediators in coronary artery bypass graft patients

CHAPTER 6. Preoperative soluble TNF-receptor levels as a risk factor in coronary artery bypass graft patients

CHAPTER 7. Enhanced preoperative C-reactive protein plasma levels as a risk factor for infections after cardiac surgery

CHAPTER 8. General discussion

CHAPTER 9. Summary/Samenvatting 


\section{List of abbreviations}

\begin{tabular}{|c|c|c|}
\hline BPI & $=$ & bactericidal/permeabiliy-increasing protein \\
\hline $\mathrm{CABG}$ & $=$ & coronary artery bypass grafting \\
\hline CK & $=$ & creatine kinase \\
\hline $\mathrm{CK}-\mathrm{MB}$ & $=$ & creatine kinase isoenzyme-MB \\
\hline $\mathrm{CPB}$ & $=$ & cardiopulmonary bypass \\
\hline CRP & $=$ & C-reactive protein \\
\hline ELISA & $=$ & enzyme-linked immunosorbent assay \\
\hline FABP & $=$ & fatty acid-binding protein \\
\hline ICAM-1 & $=$ & intercellular adhesion molecule-1 \\
\hline IL -1 & $=$ & interleukin-1 \\
\hline IL-6 & $=$ & interleukin-6 \\
\hline IL-8 & $=$ & interleukin-8 \\
\hline L.BP & $=$ & lipopolysaccharide binding protein \\
\hline MI & $=$ & myocardial infarction \\
\hline nonCPB & $=$ & $\mathrm{CABG}$ surgery without the use of $\mathrm{CPB}$ \\
\hline $\mathrm{PMN}$ & $=$ & polymorphonuclear leukocytes \\
\hline$s$ & $=$ & soluble \\
\hline STNF-R55 & $=$ & soluble TNF-receptor -55 \\
\hline STNF-R75 & $=$ & soluble TNF-receptor-75 \\
\hline $\mathrm{TNF}^{-}-\alpha$ & $=$ & tumor necrosis factor- $\alpha$ \\
\hline VCAM & $=$ & vascular cell adhesion molecule \\
\hline
\end{tabular}




\section{CHAPTER}

\section{General introduction and outline of the thesis}

"Inflammation in itself is not to be considered as a disease... and in disease, where it can alter the diseased mode of action. it likewise leads to a cure;

but where it cannot accomplish that salutary purpose ... it does mischief"

John Hunter: Treatise on the Blood, Inflammation, and Gunshot Wounds, London, 1794 (As cited by E.M. Boyle and colleagues, Ann Thorac Surg 1997:64:531-7) 


\section{GENERAL INTRODUCTION}

Although inflammation is an innate salutary process, it was recognized already two centuries ago that injury could lead to an abnormal response with a malignant systemic spread of inflammation. A similar pattern of systemic injury was recognized in the early years of cardiac surgery. Among the first to describe this phenomenon was JK Kirklin, who introduced the term "whole body inflammatory response". Generally, despite the normal convalescence of the vast majority of patients undergoing cardiac operations, all patients develop a non-infectious systemic inflammatory response during and after surgery. This response, which is considered to be self-limiting, involves both formed and unformed blood elements that normally act localiy at sites of injury. Clinically, the systemic inflammatory response is associated with fever, fluid shifts, bleeding, hemodynamic instability, and, in severe cases, organ dysfunction.

Until the early nineties, the systemic inflammatory response during and after cardiac surgery was characterized by activation of the complement system [1-3]. Then, other inflammatory mediators were identified as potential agents in the response. Cytokines were recognized as the physical messengers of the inflammatory response. Experimental studies showed that administration of one of the pivotal cytokines in inflammation, tumor necrosis factor-alpha (TNF- $\alpha$ ), to humans and animals elicits identical inflammatory manifestations as those found after cardiac surgery. Subsequently, also because of the rapid development of new immunochemical assays for detection and quantification of these inflammatory products, many studies reported on cytokine release as a prominent feature of the systemic inflammatory response to cardiac surgery.

However, despite the fact that the cytokine release profiles in cardiac surgical patients have been gradually unraveled, still some important questions remain unanswered. First, although, or because, the cardiopulmonary bypass procedure $(C P B)$ is generally accepted to be the major initiator of cytokine release, other procedures during the course of the operation and the preoperative inflammatory state of the patient have not been taken into consideration. Second, although cytokine release into plasma is considered to be a prominent feature of the systemic inflammatory response to cardiac surgery, the clinical relevance of these increased plasma levels has not been established yet. The present thesis describes the results of studies addressing these topics. The first part of this first chapter gives a summary of the literature on the release of cytokines in response to cardiac surgery. and discusses possible causes and the clinical relevance of cytokine release in cardiac surgery. Part two describes the outline of the thesis. 


\subsection{CYTOKINE RELEASE DURING CARDIAC SURGERY}

Numerous studies have detailed the presence and time course of circulating cytokines as they are released in response to cardiac surgery. Cytokines that are often reported to be released during and after cardiac surgery include TNF- $\alpha$. interleukin (IL)-1, IL-2, and IL-6.

TNF- $\alpha$. TNF- $\alpha$ is a pivotal cytokine in all inflammatory responses, and was one of the first cytokines to be implicated in the systemic inflammatory response to cardiac surgery. The physiological effects of TNF- $\alpha$ effects include hypotension, fever, and increased production of acute phase proteins. Many studies have shown increased plasma levels of TNF- $\alpha$ during and after cardiac surgery [4-14], but the data are not consistent. In some studies, TNF- $\alpha$ did not increase [15-23], or could not be detected [24]. Butler and colleagues [25] detected TNF- $\alpha$ in some patients preoperatively, but found no perioperative changes in TNF- $\alpha$ levels. The failure to detect TNF- $\alpha$ in plasma of cardiac surgical patients may be related to timing of samples and/or assay sensitivity.

$\underline{I L-1 .}$ IL-1 is another pivotal cytokine in the systemic inflammatory response to cardiac surgery. IL-1 is an important link between activation of the systemic inflammatory response and the cell-mediated immune response $[26 \mid$, and shares many of the biological properties of TNF- $\alpha$. Like TNF- $\alpha$, levels of $\mathrm{IL}-1$ have been reported to be increased during cardiac surgery $15,8,11,15,17,22,27$, 28]. Like TNF- $\alpha$, however, in some studies IL-1 could not be demonstrated $[16,29]$. Possible reasons for these inconsistent findings include poor assay sensitivity, and adequate timing of sampling in relation to changing plasma concentrations.

IL-2. IL-2 is a cytokine involved in the cell-mediated immune response 126 , 27 . Reduced as well as unchanged IL-2 levels in response to cardiac surgery have been reported $[17,30,31]$. In the same studies, levels of $I L-2 R$ were shown to be reduced [30], or increased $[3 \rrbracket]$ in response to cardiac surgery. Increased IL-2R levels are thought to represent an attempt to modulate the immune response [32]. Faist and colleagues [33] showed that the ability of cells to synthesize IL-2 is imparred after cardiac surgery, which results in an impaired cell-mediated immune response.

IL-6. Probably partly as a result of the inconsistent findings of the cytokines discussed above, IL-6 has received much attention in cardiac surgical literature during the last years. IL-6 is released in response to endotoxin, TNF- $\alpha$ and IL- -1 $[34,35]$, and usually appears in plasma 30 minutes to 2 hours after a stimulus, and peaks at 4 to 6 hours after the stimulus. The appearance in plasma charac- 
teristically precedes the increase in acute phase protein levels $[36]$. In contrast to the previous cytokines, levels of IL-6 are consistently increased in response to cardiac surgery $[5,7,8,13,14,17,19-23,27,29,37-44]$.

The release of other inflammatory mediators has also been shown to increase in response to cardiac surgery. Plasma levels of elastase, an enzyme released from granules of human polymorphonuclear leukocytes upon activation, were shown to be enhanced following cardiac surgery $[25,45,46]$. Elastase might be practicable in cardiac surgical patients since it is known to be involved in tissue injury. Recently, increased plasma levels of circulating or soluble forms of leukocyte adhesion molecules (E-selectin, ICAM-1, VCAM) have been observed during and after cardiac surgery $[21,44,47,48]$. Enhanced plasma levels of circulating or soluble adhesion molecules are generally considered to reflect an enhanced inflammatory response, but may also reflect endothelial damage [49]. Furthermore, plasma levels of both types of soluble tumor necrosis factor receptors, sTNF-R55 and STNF-R75, were shown to increase after cardiac surgery, and to allow early prognostication of subsequent hospital course [50]. These markers may also be useful to identify the mechanisms involved in the systemic inflammatory response to cardiac surgery.

\subsubsection{CAUSES OF CYTOKINE RELEASE IN CARDIAC SURGERY}

The release of cytokines in response to cardiac surgery may be initiated by a number of processes related to the use of cardiopulmonary bypass.

Tissue damage and complement activation

In the majority of the studies that were published during the last two decades on the systemic inflammatory response to cardiac surgery, the perioperative release of proinflammatory cytokines was associated with the CPB procedure. Generally, the exposure of blood to artificial surfaces, and the formation of heparinprotamine complexes at discontinuation of CPB are thought to result in activation of the complement system $[3,51]$. Thus, complement activation resulting from the use of extracorporeal circulation is considered a major contributor of the systemic inflammatory response.

Complement activation during cardiac surgery was originally shown by Parker and colleagues [52]. Since then, many studies were focussed on reducing complement activation by improving the biocompatibility of the extracorporeal 
circuit. Initially, these studies were aimed at the oxygenator used in the extracorporeal circuit. Blood activation during cardiopulmonary bypass was considered to be dependent on the use of a bubble oxygenator or a membrane oxygenator. Cavarocchi and colleagues [53], showed higher complement activation in bubble oxygenators as compared to membrane oxygenators, whereas Videm and colleagues [54], showed higher complement activation in membrane oxygenators. Other investigators, however, have shown similar degrees of complement activation with the use of either oxygenator [47, 55-58]. Videm and colleagues [59] showed that the use of a heparin-coated oxygenator in combination with heparin-coated tubings markedly reduced complement activation. In addition, Butler and colleagues [29], showed similar [L-6 responses to either oxygenator used.

During the last decade, coating of the inner surface of (parts of) the extracorporeal circuit in order to increase biocompatibility has received much attention. Heparin-coated extracorporeal circuits have been shown to reduce complement activation $[6,59-64]$, and to inhibit the release of proinflammatory cytokines $[6,21,65]$.

\section{Ischemia-reperfusion injury}

Systemic and myocardial ischemia-reperfusion injury during and after the cardiopulmonary bypass procedure with aorta cross-clamping have also been considered to contribute to the systemic inflammatory response to cardiac surgery.

There is general consensus about the involvement of neutrophils as the primary effector cells in ischemia-reperfusion-induced injury |66|. Therefore, mechanical filtration of leukocytes during CPB has been examined as a possibility to ameliorate or even prevent such injury $[42,67-72]$. Promising results were reported in animal studies, where the use of leukocyte depleting filters in the $\mathrm{CPB}$ circuit was demonstrated to reduce ischemic damage during surgical revascularization [73], and to improve postischemic recovery of left ventricular function $[74,75]$.

There is however no consensus on the efficacy of the use of leukocyte depleting filters in the clinical setting. Gu and colleagues 167], showed that although leukocyte depletion improved postoperative lung function, IL-6 plasma levels were similar in patients in whom leukocyte depletion filters were used and in control patients that did not receive these filters.

In several studies, leukocyte-depletion of blood cardioplegia administered 
early during reperfusion was shown to be beneficial in particular groups of patients undergoing cardiac surgery $[68,70,72,76]$. Especially patients with left ventricular dysfunction [70], left ventricular hypertrophy [68], and patients with preoperative nyocardial ischemic injury [72] were shown to profit from leukocyte-depletion upon reperfusion. Others showed that systemic leukocyte depletion through a leukocyte-depleting arterial blood filter incorporated in the extracoporeal circuit, did not improve postoperative lung function [69] or postoperative clinical performance parameters $[42,71]$. Remarkably, Mihaljevic et al. [69] did not even observe a significant reduction in leukocyte count when a leukocyte-depleting filter was used. Therefore, although the link between leukocyte-depletion and attenuation of ischemia-reperfusion-induced injury is tempting, the clinical efficacy of leukocyte-depleting filters in cardiac surgery is still debated.

\section{Endotoxin release}

The unphysiologic circulatory state during $\mathrm{CPB}$, a combination of redistribution of blood flow away from the mucosa and an increased oxygen demand, has been hypothesized to lead to gut mucosal ischemia [77], and an increased intestinal permeability $[18,78-80]$. These are thought to lead to an increased translocation of endotoxin across the gut wall. Subsequently, endotoxin may cause production of cytokines (e.g. IL-1, IL-6) and complement, and the activation of neutrophils, and endothelial cells (with additional IL-1, IL-6, and IL-8 secretion) $[34,81-85]$.

In many studies, increased concentrations of endotoxin (endotoxemia) have been measured in plasma during CPB $[20,37,85-93]$. As indicated above, the gut is thought to be an important source of endotoxin during cardiopulmonary bypass $[18,79,80,93,94]$. However, in one study the authors showed both an increased intestinal permeability and increased endotoxin levels, but were unable to demonstrate a relationship between both phenomena [95]. Funthermore, others showed both an elevation of endotoxin levels and mucosal acidosis, but were unable to demonstrate a significant correlation between the two parameters, indicating that endotoxin levels do not correlate with the level of gut ischemia [18]. These findings findings suggest that the increase in intestinal permeability may not be the primary cause for the increased endotoxin levels. There also have been inconsistent findings on the correlation of the duration of $\mathrm{CPB}$ and aortic cross-clamping and peak endotoxin levels $\llbracket 87,90$, 96]. Furthermore, no obvious correlation between endotoxin levels and 
postoperative morbidity has been shown [90,97], whereas others were unable to demonstrate endotoxemia during cardiopulmonary bypass at all $[24,98,99]$.

In conclusion, a number of obvious causes for the release of cytokines during and after cardiac surgery were studied. However, most findings were inconsistent and failed to establish a definite answer to the question what causes the increase in cytokine levels.

\subsubsection{POSSIBLE CLINICAL RELEVANCE OF CYTOKINES IN CARDIAC SURGERY}

Although the literature has been replete with studies demonstrating elevated plasma levels of inflammatory mediators in patients undergoing cardiac surgery, the vast majority of these studies simply identified the presence of these mediators without showing some relevance to patient morbidity after cardiac surgery. In addition, a reduction of cytokine levels and improved clinical parameters has been shown in only few studies.

Hennein and colleagues $[100]$ showed that postoperatively increased proinflammatory cytokine levels (IL-6 and IL-8) positively correlated with left ventricular wall motion abnormalities and the incidence of postoperative myocardial ischemia in patients undergoing uncomplicated coronary revascularization. Te Velthuis and colleagues [9], showed that elderly patients $(\geq 65$ years) had higher endotoxin concentrations at aortic unclamping, and higher TNF- $\alpha$ concentrations during the initial hours in the cardiosurgical intensive care unit than younger patients ( $\leq 55$ years), which coincided with a suppressed myocardial performance.

Although they did not show direct correlations, Gu and colleagues 167], showed that although postoperative lung function improved in patients in whom the residual blood from the heart-lung machine was leukocyte depleted before administration, IL-6 levels in these patients were similar to those found in control patients. These data suggest that $[L-6$ levels do not correlate with postoperative lung function.

As for cytokines, the clinical relevance of complement activation during cardiac surgery is still uncertain. While some investigators found that postoperative C3a plasma levels could predict postoperative complications $[2,101]$, others were unable to demonstrate a correlation between complement activation and acute lung injury $[17,102,103]$, or hemodynamic responses 117,104$]$. In 
fact, Wakefield et al even concluded that patients with highest complement activation exhibited the least hemodynamic changes early after heparin reversal with protamine [104].

Because of the limited data available on the comelation of cytokines with clinical data, the association between cytokines and clinical parameters in patients undergoing cardiac surgery needs to be further investigated.

\subsubsection{ALTERNATIVE CAUSES OF CYTOKINE RELEASE IN CARDIAC SURGERY}

As apparent from the previous sections, the release of inflammatory mediators in response to cardiac surgery has particularly been associated with the cardiopulmonary bypass procedure. However, several other factors might be involved in the systemic inflammatory response in cardiac surgery, which may explain inconsistent findings in the clinical efficacy of mechanisms examined to reduce systemic inflammation.

First, as was recognized already 20 years ago, tissue injury associated with (surgical) trauma, operative stress or ischemia leads to systemic complement activation [105-109]. Furthermore, other types of surgery, which do not use extracorporeal circulation, have also been associated with release of cytokines and other inflammatory mediators [110-115]. Therefore, although the cardiopulmonary bypass procedure has been recognized as a causative factor in systemic inflammation to cardiac surgery, the acute phase response to trauma, in which cytokines are intimately involved, may be an integral part of this process as well.

Second, patients" preexisting conditions have not been taken into account. However, preexisting conditions of the patients can already be pathologic with respect to the inflammatory state. In patients with severe congestive heart failure, plasma levels of STNF-R55 and STNF-R75 were shown to be increased and correlated with the severity of the disease [116]. Others showed that increased circulating concentrations of the acute phase reactant $\mathrm{C}$-reactive protein are predictors of coronary events in patients with stable as well as unstable angina [117, 118]. In addition, chronic activation of immune cells has been linked to atherogenesis and/or progression of atherosclerosis [119]. These data indicate that at least in some patients undergoing cardiac surgery inflammatory processes are already activated prior to surgery. Since it is known that the ability of a cell to synthesize pro- and anti-inflammatory mediators is influenced 
by its previous state of activation [120], patients undergoing cardiac surgery with preoperatively elevated levels of inflammatory mediators might respond differently to surgery than those patients with nomal plasma levels of these inflammatory mediators.

Finally, non-surgical factors might also influence the release of inflammatory mediators. In the past, blood transfusions have been shown to activate complement $[121,122]$. Since the administration of allogeneic blood transfusions is common use in cardiac surgery, these transfusions might influence the inflammatory response to surgery. Furthermore, endotoxin was shown to be present in a variety of fluids other than blood, including fluids administered during the operation (the cardioplegic fluids, the priming fluids for the extracorporeal circtit, blood transfusions, and the ice for local cooling) [86, 90], and in several types of pharmaceutical and medical technical material [123, 124]. Therefore, administration of these fluids during surgery, might affect the inflammatory response to surgery.

\subsection{OUTLINE OF THE THESIS}

From the previous introduction it can be concluded that the putative central role of the $\mathrm{CPB}$ procedure in eliciting the systemic inflammatory response to cardiac surgery is disputable.

First, recent studies suggest that the surgical procedure per se may play a major role in the systemic inflammatory response to cardiac surgery [110-115]. Therefore, the question arises as to what extent the systemic inflammatory response in patients undergoing cardiac surgery is merely a response to surgical trauma, and to what extent the $\mathrm{CPB}$ procedure contributes to this response. Second, recent studies suggest that in patients elicited for cardiac surgery inflammatory processes are already activated prior to surgery [116-1191, which may affect the inflammatory mediator release to surgery. Finally, additional procedures during the course of the operation may affect the inflammatory response to cardiac surgery $186,90,121-1241$.

Based on these premises we hypothesized that there may be altemative factors that play a major role in inducing the systemic inflammatory response to cardiac surgery. The main objective of this thesis, therefore, was to identify factors other than those related to the CPB procedure, that are associated with the systemic inflammatory response and the acute phase response after cardiac surgery. 
We therefore investigated to what extent the systemic inflammatory response after cardiac surgery is caused by the intra-operative trauma itself. For this, we studied inflammatory mediators in patients who underwent coronary revascularization on a beating heart without the use of $\mathrm{CPB}$. We compared the plasma levels of inflammatory mediators in these patients with plasma levels found in low-risk patients who had surgery with use of CPB. The results obtained from this study are described in chapter 2.

In chapter 3 we studied whether the administration of allogeneic blood transfusions during cardiac surgery modifies the surgery indluced release of inflammatory mediators.

We also studied the impact of ischemia-reperfusion injury during and after aortic cross clamping on the systemic inflammatory response and the acute phase response. For this, we needed a reliable tool to estimate the amount of ischemia-reperfusion injury in our patients. More importantly, it was necessary to be able to separate the ischemia-reperfusion injury from myocardial injury due to a postoperative myocardial infarction (MI). Therefore, in chapter 4 we studied the plasma release of enzymes and of the small cytosolic proteins hearttype fatty acid-binding protein (FABP, $15 \mathrm{kD})[125]$ and myoglobin $(17 \mathrm{kD})$ $[126,127]$ in low-risk patients having coronary artery bypass grafting (CABG) either with or without $\mathrm{CPB}$ and aortic cross-clamping. We investigated whether global ischaemia and reperfusion, as occurring in patients having coronary artery bypass grafting (CABG) with use of CPB and aortic cross-clamping, results in early myocardial injury detectable from increased plasma levels of cardiac proteins. Furthermore, we studied the release of these enzymes and markers in patients having $\mathrm{CABG}$ with $\mathrm{CPB}$ and aortic cross clamping who were at high risk for developing a postoperative MI. In these patients, we analyzed whether the use of more rapidly released and more cardiospecific markers allowed us to separate myocardial injury as a result of ischemiareperfusion from myocardial injury due to a postoperative $\mathrm{MI}$.

In chapter 5 we investigated the correlation between ischemia-reperfusioninduced injury during and atter aortic cross-clamping, as reflected by enzymes and cardiac proteins, and inflammatory mediators in patients undergoing CABG. For this, we correlated plasma levels of cardiac marker proteins and enzymes with plasma levels of inflammatory mediators in patients undergoing $\mathrm{CABG}$ with or without $\mathrm{CPB}$.

In order to investigate the impact of preexisting patient characteristics on the systemic inflammatory response and postoperative morbidity we studied plasma levels of several markers of inflammation. First, we measured plasma levels of 
IL-6, sTNF-R55, sTNF-R75, sE-selectin, and sICAM-1 in high-risk patients who underwent coronary artery bypass grafting (CABG), and conrelated preoperative plasma levels of these markers with parameters of postoperative performance. The results obtained from this study are shown in chapter 6 .

To further investigate the impact of the preoperative inflammatory state on postoperative performance in patients undergoing cardiac surgery, we measured plasma levels of the acute phase reactant $C$-reactive protein (CRP), and studied whether patients with preoperatively elevated levels of CRP are at increased risk for developing postoperative infections. The results of this investigation are described in chapter 7.

A general discussion on the data described in chapters 2 to 7 is found in chapter 8 .

\section{REFERENCES}

1. Chenoweth DE, Cooper SW, Hugli TE, ef al. Complement activation during cardiopuImonary bypass: evidence for generation of C3a and C5a anaphylatoxins. N Engl J Med $1981 ; 304: 497-503$.

2. Kirklin $\mathrm{JK}$, Westaby $\mathrm{S}$, Blackstone $\mathrm{EH}$, et al. Complement and the damaging effects of cardiopulmonary bypass. J Thorac Cardiovase Surg 1983;86:845-57.

3. Kirklin JK, Chenoweth DE, Naftel DC, et al. Effects of protamine administration after cardiopulmonary bypass on complement, blood elements, and the hemodynamic state. Ann Thorac Surg 1986;41:193-9.

4. Jansen $N J$, van Oeveren $W$, van den Broek $L$, et al. Inhibition by dexamethasone of the reperfusion phenomena in cardiopulmonary bypass. J Thorac Cardiovasc Surg 1991:102: $515-25$

5. Markewitz A, Faist E, Lang S, Endres S, Hülther L, Reichart B. Regulation of acute phase response after cardioplumonary bypass by immunomodulation. Ann Thorac Surg 1993: 55: $3999-94$

6. Gu YJ, van Oeveren W, Akkerman C, Boonstra PW, Huyzen RJ, Widdevutr CR. Heparincoated circuits reduce the inflammatory response to cardiopulmonary bypass. Ann Thorac Surg 1993;55:917-22.

7. Journois D, Pouard P, Greeley WJ, Mauriat P, Vouhe P, Safran D. Hemoflitration during cardiopulmonary bypass in pediatric cardiac surgery. Effects on hemostasis, cytokines. and complement components. Anesthesiology 1994:81:1181-9.

8. Menasché $P$. Haydar $S$, Peynet d, et al. A potential mechanism of vasodilation after warm heart surgery. J Thorac Cardiovase Surg 1994;107:293-9.

9. Velthuis $H$, Jansen $P G$, Oudemans van Straten $H M$, Sturk $A$, Eijsman $L$, Wildewur CR. Myocardial performance in elderly patients atter cardiopulmonary bypass is suppressed by tumor necrosis factor. I Thorac Cardiovasc Surg 1995;110:1663-9.

10. Tönz M, Mihaljevic T, van Segesser LK, et all. Normothermia wersus hypothermia during cardiopulmonary bypass: a randomized, controlled trial. Ann Thorac Surg 1995:59:137. 43.

11. Tabardel Y, Duchateau J. Schmartz D, et al. Conticosteroids increase blood interleukin-10 levels during cardiopulmonary bypass in men. Surgery 1996;119:76-80. 
12. Jansen $P G$, te Velthuis $H$, Wildevuur $W$, el al. Cardiopuimonary bypass with moditied fluid geialin and heparin-coated circuits. Br J Anaesth 1996;76:13-9.

13. Wang MJ Chiu IS. Hsu CM, et al. Efficacy of ultralittration in removing inflammatory mediators during pediatric cardiac operations. Ann Thorac Surg 1996:6*:651-6.

14. Wan S, Marchant A, DeSmet AM, at al. Human cytokine response to cardiac transplantation and coronary artery bypass grafting. IThorac Cardiovasc Surg 1996;111:469 77.

15. Haetfiner-Cavaillon $N$, Roussellier $N$, Ponzio $O$, et al. Induction of interteukin-1 production in patients undergoing cardicpulmonary bypass. I Thorac Cardiovasc Surg 1989;98:11006.

16. Finn A, Moat $N$, Rebuck $N_{8}$ Klein $N$, Strobel S, Elliott M. Changes in neutrophil CD11b CD18 and L-selectin expression and release of interleukin 8 and elastase in paediatric cardiopumonary bypass. Agents Actions 1993;38:C44-6.

17. Steinberg JB, Kapelanski DP, Olson JD, Weiler JM. Cytakine and complement levels in patients undergoing cardiopulmonary bypass. IThorac Cardiovasc Surg 1993;106:1008* 16.

18. Andersen LW, Landow $L$, Baek $L$, Jansen $E$, Baker $S$. Association between gastric intra* mucosal pH and splanchnic endotoxin, antibody to endotoxin, and tumor necrosis factoralpha concentrations in patients undergoing cardiopulmonary bypass. Crit Care Med 1993:21:210-7.

19. Holzheimer RQ, Molloy RG, Gorlach H, Wilkert S, Hehrlein F. IL-6 and TNF alpha release in association with neutrophil activation after cardiopulmonary bypass sungery. nfection $1994: 22: 37-42$.

20. Inaba $\mathrm{H}_{\text {, Kochi A }}$ Yorozu S. Suppression by methylprednisolone of augmented plasma endoloxin-like activity and interleukin- 6 during cardiopulmonary bypass. Br $J$ Anaesth $1994 ; 72: 348-50$.

21. Weerwind PW. Maessen JG, van Tits $L J H$, et all. Influence of Duraflo II heparin-treated extracorporeal circuits on the systemic inflammatory response in patients having coronary bypass. I Thorac Cardiovasc Surg 1995:110:1633-41.

22. Ohata T, Sawa $Y$, Kadoba $K$, et al. Normothermia has beneficial effects in cardiopulmonary bypass attenuating inflammatory reactions. ASAIO J 1995;41:M288-91.

23. Cremer $\mathrm{J}$, Martin $\mathrm{M}$, Redl $\mathrm{H}$, et al. Systemic inflammatory response syndrome after cardiac operations. Ann Thorac Surg 1996;61:1714-20.

24. Frering $B$, Philip I, Dehoux M, Rolland $C_{n}$ Langlois JM, Desmonts JM. Circulating cytokines in patients undergoing nomothernic cardiopulmonary bypass. I Thorac Cardiovasc Surg 1994;108:636-41

25. Butler J, Parker D, Pillai A, Westaby S, Shale DJ. Rocker GM. Effect of cardiopulmonary bypass on systemic release of neutrophil elastase and tumor necrosis factor. I Thorac Cardiovasc Surg 1993; 105:25-30.

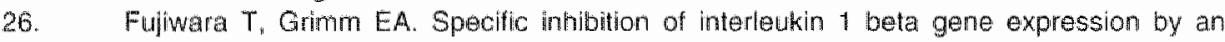
antisense oligonucleotide: obligatory role of interleukin 1 in the generation of lymphokineactivaled killer cells. Cancer Res 1992;52:4954-9.

27. Markewitz A, Feist E, Lang S, Endres S. Fuchs D, Reichart B. Successfut pestoration of cell-mediated immune response after cardiopulmonary bypass by immunomodulation. I Thorac Cardiowase Surg 1993:105:15-24.

28. Engelman RM, Rousou JA, Flack JE, Deaton DW, Kalfin F, Das DK. Unfluence of steroids on complement and cytokine generation after cardiopulmonary bypass. Ann Thorac Surg $1995 ; 60: 801-4$.

29. Butler J, Chong GL, Baigrie RJ, Pillai R. Westaby S, Rocker GM. Cyiokine responses to cardiopulmonary bypass with membrane and bubble oxygenation. Ann Thorac Surg 1992; 53:833-8. 
30. Deng MC, Wiedner M, Erren M, Mölhotf $T$, Assmann $G$, Scheld HH. Arterial and venous cytokine response to cardiopulmonary bypass for low risk CABG and relation to hemodynamics. Eur J Cardiothorac Surg 1995;9:22-9.

31. Saatvedt $K$, Lindberg $H_{\text {, Geiran }} \mathrm{OA}_{\text {, el }}$ al. Complement activation and release of tumour necrosis factor alpha, interleukin-2, interleukin-6 and soluble tumour necrosis factor and interleukin-2 receptors during and after cardiopulmonary bypass in children. Scand $I$ Chin Lab lovest 1995; 55:79-86.

32. Hall FI, Smith MS, Rocker G. The systemic inflammatory response to cardiopulmonary bypass: pathophysiological, therapeutic, and pharmacological considerations. Anesth Analg 1997;85:766-82.

33. Faist E, Markewitz A. Fuchs D, et al Immunomodulatory therapy with thymopentin and indomethacin. Successful restoration of interleukin-2 synthesis in patients undergoing major surgery. Ann Surg 1991;214:264.75.

34. Fong $Y$, Moldawer LL, Marano $M$, et al Endotoxemia elicits increased circulating beta 2 . IFN/LL-6 in man. J Imrmunol 1989; $142,2321-4$.

35. Zhang $Y$, Lin J-X, Yip $Y K_{*}$, Vilcek J. Stimulation of interleukin-6 inRNA levels by tumor necrosis factor and interleukin-1. Ann N Y Acad Sci 1989:557:548-9.

36. Pullicino $E A$, Carli $F$, Poole $S$, et al. The relationship belween the circulating concentrations of interleukin 6 (IL6) and tumor necrosis factor (TNF) and the acute phase response to elective surgery and accidental injury. Lymph Res 1990;9:231-8,

37. Martinez Pellus AE, Merino P, Bru M, et al. Can selective digestive decontamination avoid the endotoxemia and cytokine activation promoted by cardiopulmonary bypass? Crit Care Med 1993;21:1684.91.

38. Markewitz A, Faist $E$, Weinhold $C$, et al. Alterations of cell-mediated immune response Iollowing cardiac surgery. Eur J Cardiothorac Surg 1993:7:193-9.

39. Hill GE, Snider $S$, Galbraith TA. Forst $S$, Robbins RA. Glucocorticoid reduction of bronchial epithelial inflammation during cardiopulmonary bypass. Am J Respir Crit Care Med 1995:152:1791-5.

40. Kawamura $T$, inada $K$, Okada $H$, Okada $K$, Wakusawa R. Methylprednisolone inhibits increase of interleukin 8 and 6 during open heart surgery. Can J Anaesth 1995:42:399. 403.

41. Journois $D$. Pouard $P$, Rolland $B$, Lagarde $M$. Uittrafiltration allows to reduce cytokine plasma concentrations during pediatric cardiopulmonary bypass. Contrib Nephrol 1995; 116:86-8.

42. Johnson D. Thomson D. Mycyk T. Burbridge B, Mayer's I. Depletion of neutrophills by fitter during aortocoronary bypass surgery transiently improves postoperative cardiorespiratory status, Chest 1995:107:4253-9.

43. Sawa $Y$, Shimazaki $Y$. Kadoba $K$, ef al. Altenuation of cardiopulmonary bypass-derived inflammatory reactions reduces myocardial reperfuision injury in cardiac operations. J Thorac Cardiovasc Surg 1996;111:29-35.

44. Kawamura $T$, Inada $K$, Akasaka $\mathbb{N}$, Wakusawa $R$. Ulinastatin reduces elevation of cytokines and soluble adhesion molecules during cardiac surgery. Can J Anaesfh 4996; $43: 456 \cdot 60$.

45. Riegel W. Spillner G, Schlosser V. Horl WH. Plasma levels of main granulacyte components during cardiopulmonary bypass. J Thorac Cardiovasc Surg 1988;95:1014 4 .

46. Gu Y』, Van Oeveren W. Boonstra PW. De Haan J, Wildevuur CRH. Leukocyte activation with increased expression of CR3 receptors during cardiopulmonary bypass. Ann Thorac Surg 1992;53:839-43.

47. Gillinov $\mathrm{AM}$. Bator $\mathrm{MM}$, Zehr $\mathrm{KJ}$, et al. Neutrophil adhesion molecule expression during cardiopulomary bypass with bubble and membrane oxygenators. Ann Thorac Surg 1993; $56: 847-53$. 
48. Sold I, Osmer $\mathrm{C}$, Linke LC, Gorach $\mathrm{G}$, Hempelmann $\mathrm{G}$. Hypothemic versus nomothemic watiopumonary bypass: influence on circulating adhesion molecules. $J$ Cardiothorac Vasc Anesth 1996;10:342-7.

49. Boldt J. Kumle B, Papsdonf M, Hempelmann G. Are circulating adhesion molecules specifically changed in cardiac surgical patients? Ann Thorac Surg $1998 ; 65: 608-14$.

50. Pilz G. Fraunberger $P$, Appel $R$, et al. Eally prediction of outcome in score-identified, postcardiac surgical patients at high risk tor sepsis, using solutble tumor necrosis factor receptor-p55 concentrationis. Crit Care Med 1996,24:596-600.

51. Cavarocchi H $_{\text {. Schaff } H W}$, Orszulak $T A$, et al. Evidence for complement activation by protamine-heparin interaction after cardiopulmonary bypass. Surgery 1985;98:525-31.

52. Parker DJ, Cantrell WW. Karp RB Stroud AM. Digemess SB. Changes in serum complement and immunoglobins following cardiopulmonary bypass. Surg 1972; $71: 824-7$.

53. Cavarocchi NC, Pluth JP, Schaff HV, et al. Complement activation during cardiopul monary bypess. Comparison of bubble and membrane oxgenators. I Thorac Carotiovasc Surg 1986:91:252.8.

54. Videm V, Fosse E, Mollines TE, Garred P. Svennevig JL. Complement activation with bubble and membrane oxygenators in aortocoronary bypass grafting. Ann Thorac Surg $1990 ; 50: 387-91$.

55. Hammerschmidt DE, Stroncek DF, Bowers TK, et al. Complement activation and neutrow penia occurning during cardiopumonary bypass. It Thorac Cardiovasc Surg 1981; 81,3707.

56. van Deveren W, Kazatchkine MD, Descamps-Latscha. B, et al. Deleterious effects of cardiopulmonary bypass. A prospective study of bubble versus membrane oxygenation. I Thorac Cardiovasc Surg 1985; 89:888-99.

57. Mickleborough LL. Amold G, Chiu RCl. Complementi consumption during cardiopulmonary bypass: bubble wersus membiane oxygenators. Perfusion 1986;1:261-9.

58. Nilsson $L$. Nisson $U$, Venge $P$, et al. Inflammatory system activation during cardiopulmonary bypass as an indicator of biocompatibility: a randomized comparison of bubble and membrane oxygenators. Scan I Thorac Cardiovasc Surg 1990;24:53-8.

59. Videm TE, Svennevig uL, Fosse E, Semb G, Ostierud A, Mollnes TE. Feduced complement activation with heparin coatted oxygenator and lubings in coronay bypass operations. I Thovac Cardiowase Surg 1992;103:806-13.

60. Mollnes $T E$, Videm $V$, Gotze $O$, Harboe $M$. Oppermann $M$. Formation of C5a during cardiopulmonary bypass: Inhibition by precoating with heparin. Ann Thorac Surg 1991:52: $92 \times 7$.

61. Pekna M, Hagman $L_{\text {. Halden }}$. Nilsson UR, Nisson B, Thelin S. Complement activation during cardiopulmonary bypass: eftects of immobilized heparin. Ann Thorac Surg 1994: $58: 421 \div 4$.

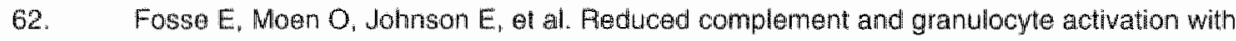
heparim-coated cardiopulmonary bypass. Ann Thorac Surg 1994;58:472-7.

63. Ovnum E, Molmes TE, Fosse E, et al. High and low heparin dose with heparin-coated cardiopulmonary bypass: activation of complement and granulocytes. Ann Thorac Surg $1995 ; 60: 1755 \% 61$.

64. Moen O. Hogasen K, Fosse E, et al. Attenuation of changes in leukocyte surface markers and complement activation with heparin coated cardiopumonry bypass. Ann Thorac Surg $1997 ; 63: 105-11$.

65. Steinberg BM. Grossi EA, Schwartz DS, at al. Heparin bonding of bypass circuits reduces cytokine release during cardiopumonary bypass. Ann Thorac Surg 1995;60:525-9.

66. Welboum CA, Goldman G, Paterson IS, Waleri CR, Shepro D, Hechtman HB. Pathophysiology of ischaemia-reperfusion injury: central role of the neutrophil. Br \& Surg $199 \% ; 78$ : $651 \cdot 5$ 
Gu YJ, de Vries AJ, Boonstra PW, van Oeveren W. Letkocyte depletion results in improved lung function and reduced inflammatony response after cardiac surgery. $J$ Thorac Cardiovase Surg 1996:112:494:500.

68. Sawa $Y$, Taniguchi $K$, Kadoba $K$, et al. Leukocyte depletion attenuates reperfusion injuly in patients with left wentricular hypertrophy. Circulation $1996 ; 93: 1640-6$.

69. Minaljevic $T$, Tonz $M_{\text {: }}$ won Segesser $L K$, ef al. The influence of leukocyte filtration during cardiopulmonary bypass on postoperative lung function. A clinical study. I Thorac Cardiovasc Surg 1995; 109: 1138-45.

70. Pala MG, Paolini G, Paroni A, ef al. Myocardial protection with and without leukocyte depletion: a comparative siludy on the oxidative stress. Eur I Cardiothorac Surg 1995:9: $701-6$

71. Englander R, Cardarelli MG. Efficacy of leukocyte filters in the bypass circuit for intants undergoing cardiac operations. Ann Thorac Surg 1995;60:5533-5.

72. Sawa $Y$, Matsuda $H$, Shimazaki $Y$, el al. Evaluation of leukocyte-depleted terminal blood cardioplegic solution in patients undergoing elective and emergency coronary artery bypass grafting. J Thorac Cardiovasc Surg 1994;108:1125-31.

73. Lazar HL, Zhang $X$, Hamasaki $T$, ef al. Role of leukocyte depletion during cardiopulmonary bypass and cardioplegic arrest. Ann Thorac Surg 1995;60:1745-8.

74. Wilson 1C, DiNatale UM, Gillimov AM, Curtis WE, Cameron DE, Gardner TJ. Leukocyte depletion in a neonatal model of cardiac surgeny. Ann Thorac Surg 1993;55:12-9.

75. Byrne JG, Appleyard RF, Lee CC, et al. Controlled reperfusion of the regionally ischemic myocardium with leukocyte-depleted blood reduces stunning, the no-reflow phenomenon, and infaret size. J Thorac Cardiovase Surg 1992;103:66-71.

76. Hachida $M$, Hanayama $N$, Okamura $T$, et al. The role of leukocyte depletion in reducing injury to myocardium and lung during cardiopulmonary bypass. ASAIO J 1995:41:M291-4.

77. Tao W, Zwischenberger JB, Nguyen TT, et all. Gut mucosal ischemia during normothermic cardiopulmonary bypass results from blood flow redistribution and increased oxygen demand. I Thorac Cardiovasc Surg 1995;110:819-28.

78. Landow L. Phillips DA, Heard SO, Prevost D, Vandersalm TJ, Fink MP. Gastric tonometry and venous oximetry in cardiac surgery patients. Crit Care Med 1991;19:1226-33.

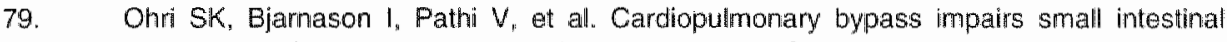
transport and increases gut permeability. Ann Thorac Surg 1993;55:1080-6.

80. Sinclair DG, Haslam PL, Quinlan GJ, Pepper JR, Evans TW. The effect of cardiopulmonary bypass on intestinal and pulmonary endothelial permeability. Chest 1995; 108: $718-24$

81. Smedly LA, Tonnesen MG, Sandhaus RA, el al. Neutrophil-mediated injury to endothellat cells: enhancement by endotoxin and essential rolle of neutrophil elastase. I Clin Invest $1986,77: 1233 \times 43$.

82. Vukajlovich SW. Hoffman J, Morrison DC. Activation of human serum complement by bacterial lipopolysaccharides: structural requirements for antibody independent activation of the classical and alternate pathways. Mol immunol 1987:24:319-31

B3. Dinarello CA. Interleukin-1 and its biologically related cytokines. Adv immunol 1989;44: 153-205.

84. Landow L, Andersen LW. Splanchnic ischaemia and its role in multiple organ talure. Acta Anaesthesiol Scand 1994:38:626-39.

85. Jansen NJG, van Oeveren W, Gu YJ, van Vliet MH, Ejjsman L, Wildevuur CA. Endotoxin release and tumor necrosis factor formation during cardiopulmonary bypass. Ann Thorac Surg 1992:54:744-7.

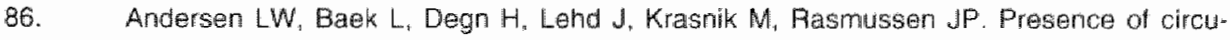
lating endoloxins during cardiac operations. I Thorac Cardiowasc Surg 1987;93:115-9.

87. Rocke DA. Gaffin SL, Wells MT, Koen Y, Brock Utine JG. Endotoxemia associated with cardiopulmonary bypass. J Thorac Cardiovasc Surg 1987;93:832-7. 
88. Kharazmi A, Andersen LW. Baek L, Vateris NH, Laub M, Rasmussen JP. Endotoxemia and enhanced generation of oxygen radicals by neutrophiss trom patients undergoing Cardiopulmonary bypass. IThorac Cardiovase Surg 1989;98;381-5.

89. Andersen LW, Baek L., Thomsen BS, Rasmussen JP. Effect of methylprednisolone on endoloxemia and complement activation during cardiac surgery. I Cardiothorac Anesth 1989;3.544-9.

90. Nilsson $L$, Kullander $L$, Wystrom SO, Eriksson $O$. Endotoxins in cardiopulmonary bypass. $J$ Thorac Cardiovase Surg 1990; 100:777-80.

91. Karlstad MD. Patteson SK, Guszcza JA, Langdon R, Chesney JT. Methylprednisolone does not influence endotoxin translocation during cardiopulmonary bypass. I Cardiotharac Vasc Anesth 1993;7:23-7.

92. Taggan DP, Sundaram $S_{\text {. McCartney }} C_{\text {, al }}$. Endotoxemia, complement, and white blood cell actiwation in cardiac surgery: a randomized trial of laxatives and pulsatile perfusion. Ann Thorac Surg 1994;57:376-82.

93. Watarida $S$. Mori A, Onoe $M_{\text {s }}$ et al. A clinical study on the effects of pulsatile cardiopulmonary bypass on the blood endotoxin levels. It Thorac Cardiovasc Surg 1994: 108:620-5.

94. Bave AE. The role of the gut in the development of multiple organ dysfunction in cardiothoracic patients. Ann Thorac Surg 1993;55:822-9.

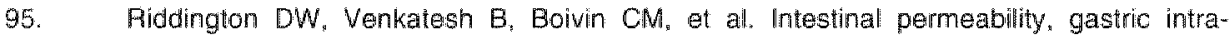
mucosal $\mathrm{pH}$, and systemic endotoxemia in patients undergoing cardiopulmonary bypass. JAMA 1996;275:1007-12.

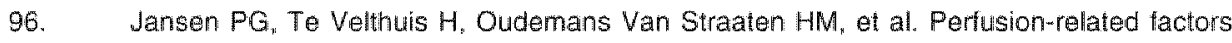
of endotoxin release during cardiopulmonary bypass. Eur I Cardiothorac Surg 1994;8: $125-9$.

97. Wan S. LeClerc Jlw Vincent JL. Inflammatory response to cardiopulmonary bypass: mechanisms involved and possible therapeutic stralegies. Chest 1997:112:676-92.

98. Quiglley RL, Caplan MS. Perkins JA, et al. Cardiopulmonary bypass with adequate flow and perfusion pressures prevents endotoxaemia and pathologic cytakine production. Perfusion 1995; 10:27-31.

99. Kelly $\mathrm{KL}, \mathrm{O}^{\prime}$ Sullivan $\mathrm{C}$, O'Riordain $\mathbb{M}$. Is circulating endotoxin the trigger for the systemic inflammatory response syndrome seen after injury? ? Ann Surg 1997;225:530-41.

100. Hennein HA, Ebba H. Rodriquez JL, et al. Relationship of the proinflammatory cytokines to myocardilal ischemia and dysfunction after uncomplicated coronary revascularization. I Thorac Cardiowaso Surg 1994; 108:626-35.

101. Moore FD. Warner KG, Assousa $S$, Valeri CR, Khuri SF. The effects of complement activation during cardiopulmonary bypass: attenuation by hypothermia, heparin, and hemodilution. Ann Surg 198:8:95: 103.

102. Tennenberg SD, Clardy CW. Baily WW, at Complement activation and lung permeability during cardiopumonary bypass. Ann Thovac Surg 1990:50:597-60\%.

103. Bando $K$. Pillai $A$, Cameron $D E_{i}$ el al. Leukocyle depletion ameliorates tree radicalmediated lung injury after cardiopulmonary bypass. I Thorac Cardiovasc Surg 1990;99: $873-7$.

104. Waketield TW, Kirsh MM, Till GO, Brothers TE, Hantler CB, Stanley JC. Absence of complement-mediated events after protamine reversal of heparin anticoagulation. I Surg Res $1991: 51: 72-6$.

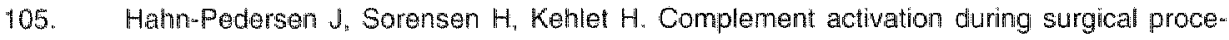
dures. Surg Gyn Obstet $1978 ; 146: 66-8$.

106. Fosse $E$, Molines TE, Ingvaldsen B. Complement activation during major operations with or without cardiopulmonary bypass. I Thorac Cardiovasc Surg 1987;93:860-6.

107. Mollnes TE, Fosse E. The complement system in trauma-rellated and ischemic tissue damage: a brief review. Shock 1994:2:301-10.

108. Schlag $G_{\text {" Red }} H$. Mediators of injury and inflammation. World J Surg 1996;20:406-10. 
109. Kochilas L. Campbell B, Scalia R. Lefer AM. Beneficial effects of $\mathrm{Cl}$ esterase inhibitor in murine traumatic shock. Shock 1997:8:165-9.

110. Crozier TA, Muller JE, Quittkat D, Sydow M, Wuttke W, Kettler D. Effect of anaesthesia on the cytokine responses to abciominal surgery. Br I Anaesth 1994:72:280-5.

111. Kato M, Suzuki H, Murakami M, Akama M. Matsukawa S. Hashimoto Y. Elevated plasma lewels of interleukin-6, interleukin-8, and granulocyte colony-stimulating factor during and after major abdominal surgery. J Clin Anesth 1997;9:293-8.

112. Chambrier $C$. Chassard $D$, Bienvenu J, et al. Cytokine and homonal changes after cholecystectony. Effect of ibuproten pretreatment. Ann Surg 1996:224:178-82.

113. Froon A.HM, Greve JWM, van der Linden CJ increased concentrations of cytokines and adhesion molecules in patients after repair of abdominal aontic aneurysm. Eur I Surg 1996; 162:287-96.

114. Kragsbjerg $P$, Holmberg $H$, Vikerfors $T$. Serum concentrations of interleukin-6, tumour necrosis factoralpha, and $C$-reactive protein in patients undergoing major operations. Eur J Surg 1995;161:17-22.

115. Ohzato $H$, Yoshizaki $K$, Nishimoto $N$, et al. Interleukin-6 as a new indicator of inflammatory status: delection of serum levels of interleukin-6 and C-reactive protein after surgery. Surgery 1992; 111:201-9.

116. Ferrari $R$, Bachetti $T$, Confortini $R_{n}$ et al. Tumor necrasis lactor soluble receptors in patients with various degrees of congestive heart falure. Circulation 1995;92:1479-86.

117. Tracey RP, Lemaitre RN, PSaty BM, ett al. Relationship of C-reactive protein to risk of cardiovascular disease in the elderly. Results from the Cardiovascular Health Study and the Rural Health Promotion Project. Anterioscler Thromb Vasc Biol 1997:17:1121-27.

118. Haverkate F, Thompson SG, Pyke SO, Gallimore JR, Pepys MB. Production of C-reactive protein and risk of coronary events in stable and unstable angina. European Concerted Action on Thrombosis and Disabilities Angina Pectoris Study Group. Lancet 1997; 349:462-6.

119. Weiss G, Willeit J, Kiechl S, et al. Increased concentrations of neopterin in carotid atherom sclerosis. Atherosclerosis 1994; 106:263-71.

120. Szabo G. Kodys K, Miller-Graziano CL. Elevated monocyte interleukin-6 (IL-6) production in immunosuppressed trauma patients. I. Role of FcgRI cross-linking stimulation. I Clin Immunol 1991;11:326-35.

121. Salama A, Mueller-Eckhardt $C$. Delayed hemolytic transfusion reactions: evidence for complement activation involving allogeneic autologous red cells. Transfusion 1984;24: $188-93$.

122. Teisner B, Brandslund I, Grunnet $\mathbb{N}$, Hansen LK, Thellesen J, Svehag SE. Acule complement activation during anaphylactoid raction to blood transfusion and the disappearance rate of $\mathrm{C} 3$ and $\mathrm{C} 3 \mathrm{~d}$ from the circulation. $J$ Clin Lab mmunol 1983:12:63-7.

123. Petersen NJ. Carson LA, Favero MS. Bacterial endotoxin in new and reuse hemodialyzers: a potential cause of endotoxemia. Trans Am soc Artil hitem Organs 1981; $27: 155-60$.

124. Shmunes $E$, Darby $T$. Contact dermatitis due to endotoxin in irradiated latex gloves. Contact Dermatitis 1984:10:240-4.

125. Van Nieuwenhoven FA, Musters RJP, Post JA, Verkleij AJ, Van der Vusse GJ, Glatz JFC. Release of proteins from isolated neonatal rat cardiomyocytes subjected to simulated I schaemia or metabolic inhibition is dependent of molecular mass. J Mol Cel Cardiol 1996; 28: $1429-34$.

126. Kinoshita $K$, Tsuruhara $Y$, Tokunaga $K$. Delayed time to peak, serum myoglobin level as an indicator of cardiac dysfunction following open heart surgery. Chest 1991;99:1398-402.

127. Isakov A, Shapira I, Burke M, Almog C. Serum myoglobin levels in patients with ischemic myocardial insult. Arch Intern Med 1988;148: 1762-5. 



\section{CHAPTER \&}

Systemic inflammation in patients undergoing coronary artery bypass grafting without extracorporeal circulation

Published in: Chest 1998;113:1290-95 


\section{ABSTRACT}

Purpose. This study was conducted to evaluate to what extent the cardiopulmonary bypass (CPB) procedure in patients undergoing coronary artery bypass grafting (CABG) contributes to the systemic inflammatory response. Therefore, we measured bactericidal permeability increasing protein (BPI) as an indicator of neutrophil activation, interleukin-6 (IL-6) as inducer of the acute phase response and lipopolysaccharide binding protein (LBP) and C-reactive protein as parameters of the acute phase response, in patients undergoing $\mathrm{CABG}$ either with or without the use of $\mathrm{CPB}$.

Methods. Sixteen patients undergoing elective CABG were included. Eight patients underwent surgery with $\mathrm{CPB}$, and 8 patients underwent surgery without CPB (NON-CPB). In the CPB group, blood samples were taken upon induction of anesthesia, at the start of aortic cross-clamping, at aortic unclamping and $0.5,4,8$ and 18 hours thereafter. In the NON-CPB group, blood samples were taken upon induction of anesthesia, and $0.5,4,8$ and 18 hours after completion of the bypass graft anastomoses.

Results. BPI release from neutrophil granules markedly increased during surgery in CPB patients but not in NON-CPB patients. The increase in acute phase reactants, however, was the same in both patient groups.

Conclusions. These data indicate that the acute phase response in CABG patients, which has historically been ascribed to the cardiopulmonary bypass procedure, is predominantly caused by the surgical procedure per se. Early neutrophil activation, however, is seen only when extracorporeal circulation is used.

\section{INTRODUCTION}

Cardiac surgery with the use of cardiopulmonary bypass (CPB) is associated with systemic inflammatory activation leading to an acute phase response with sepsis-like symptoms during postoperative recovery [1, 2]. Factors that have been assumed to lead to this systemic inflammatory response, include contact activation, ischemiatreperfusion injury, reinfusion of shed blood, hemodilution, protamine-heparin complexes, and endotoxins released from the temporary ischemic intestine [3-6]. Among these factors, complement activation resulting from the contact of blood with foreign surfaces and the subsequent activation of leukocytes and their sequestration into target organs 
is considered the major cause of capillary leakage and organ dysfunction [7-9]. Recently, we showed that reduction of contact activation and generation of inflammatory mediators by modification of the material surface of the heartlung machine $[10,11]$ resulted in a partially decreased systemic inflammatory response. The use of leukocyte depleting filters has also been reported to reduce the systemic inflammatory response [12].

Because of these findings, the CPB procedure in cardiac surgery is associated with a systemic inflammatory response and consequently contributes to postoperative morbidity. However, since other types of surgery also have been associated with a systemic inflammatory response [13], the question arises to what extent the CPB procedure contributes to the systemic inflammatory response in patients having cardiac surgery.

To avoid the detrimental effects of the $\mathrm{CPB}$ procedure, coronary revascularization performed on a beating heart without the use of $\mathrm{CPB}$ is becoming a new standard in patients with anterior descending and/or right coronary artery disease, who cannot be treated by coronary angioplasty [14]. Measuring inflammatory parameters in these patients might answer the question as to what extent the systemic inflammatory response is triggered by either the surgical procedure or the CPB procedure [15].

Therefore, in the present study we measured bactericidal permeability increasing protein (BPI) as an indicator of the polymorphonuclear leukocyte (PMN) response, interleukin 6 (IL-6) as inducer of the acute phase response and lipopolysaccharide binding protein (LBP) and C-reactive protein as parameters of the acute phase response in two groups of patients: (1) patients undergoing coronary bypass grafting (CABG) with the use of $\mathrm{CPB}$, and (2) patients undergoing $\mathrm{CABG}$ without the use of $\mathrm{CPB}$. Using these data we were able to distinguish the acute phase response and PMN activation ellicited by the surgical procedure (patient dependent) from the responses elicited by the CPB procedure (CPB dependent).

\section{MATERIALS AND METHODS}

\section{Patients}

A total of sixteen adult patients undergoing elective $\mathrm{CABG}$ were enrolled: 8 consecutive patients undergoing $\mathrm{CABG}$ with the use of $\mathrm{CPB}$ ( $\mathrm{CPB}$ group), and 8 consecutive patients undergoing $C A B G$ without the use of CPB (NON-CPB 
group). All patients in the NON-CPB group had single vessel disease and single graft surgery. None of the patients received allogeneic packed red cells intra-operatively. All subjects gave written informed consent for the study and the study was approved by the local ethical and research council.

\section{Intra-operative patient management}

Standard anesthetic (lorazepam, fentanyl citrate, sufentanil citrate, alfentanil hydrochloride, midazolam hydrochloride, pancuronium bromide) and monitoring techniques (electro-cardiogram, arterial pressure monitoring, urinary output, rectal and skin temperature monitoring) were used in all patients. Cefuroxim was used for antibiotic prophylaxis, and the first dose was administered before sternotomy.

In the CPB group, before connection to the non-heparin coated extracorporeal circuit for cardiopulmonary bypass, porcine heparin $(300 \mathrm{IU} / \mathrm{kg}$, Heparin Leo, Leo Pharmaceutical Products BV, Weesp. The Netherlands) was administered in order to achieve an activated coagulation time $>480 \mathrm{~s}$ (Hemochron 400, International Technidyne Corp., NJ, USA). Details of the extracorporeal circulation circuit and perfusion procedures have been published previously [10]. After initiation of $\mathrm{CPB}$, and after reaching a blood temperature below $28^{\circ} \mathrm{C}$, the heart was topically cooled with cold saline $0.9 \%$ at $4^{\circ} \mathrm{C}$. When fibrillation occurred, the aorta was crossclamped and a single dose of approximately $800 \mathrm{ml}(600-1000 \mathrm{ml})$ of St.Thomas-I cardioplegic solution at $4^{\circ} \mathrm{C}$ was infused into the aortic root over a period of 4 minutes (35 minutes) to provide myocardial preservation. Hypothermic pulsatile perfusion was maintained throughout the period of aorta cross-clamping. After completion of all distal anastomoses, the aortic crossclamp was removed and the proximal anastomoses was performed with a partial occlusion clamp after spontaneous or electrical defibrillation. Meanwhile the rewarming of the patient to $37^{\circ} \mathrm{C}$ continued. Heparin was neutralized by $3 \mathrm{mg} / \mathrm{kg}$ protamine chloride (Hoffman/Laroche B.V., Mijdrecht, The Netherlands).

In the NON-CPB group, after median sternotomy, coronary grafting was performed on a beating, normothermic heart. To dampen the movement of the beating heart and consequently isolate the region for anastomosis, a custommade, U-shaped stabilizer was used. Through its shaft, the stabilizer was attached to a slightly adjusted stemal retractor. Using vessel loops, a segmentary occlusion of the coronary artery to a length of approximately 2.5 $\mathrm{cm}$ was used to control its bleeding during the anastomosis. Postoperative 
patient treatment in the coronary care unit was standardized and similar for both groups.

\section{Blood sampling}

In the CPB group, blood samples were taken upon induction of anesthesia (baseline), at the start of aortic cross-clamping, at the start of reperfusion and $0.5,4,8$ and 18 hours thereafter. Samples were collected in evacuated blood collection tubes $(10 \mathrm{ML}$, Monoject, Sherwood Medical, Ballymoney, N. Ireland) containing ethylenediamine-tetraacetic acid. Immediately after sampling, the blood was cooled, centrifugated at $3500 \mathrm{rpm}$ for 20 minutes and plasma samples were stored at $-70^{\circ} \mathrm{C}$ until measurements.

In the NON-CPB group, blood samples were taken upon induction of anesihesia (baseline), and $0.5,4,8$, and 18 hours after completion of the bypass graft anastomoses (start of reperfusion). Samples were collected and treated in the same way as described for the CPB group.

\section{Measurements}

Plasma levels of BPI, IL-6 and LBP were measured using sandwich enzymelinked immunosorbent assays (ELISAs), which have been described elsewhere. In short, 96-well plates (Immuno-Maxisorp; Nunc, Roskilde, Denmark) were coated overnight at $4^{\circ} \mathrm{C}$ with the appropriate antibodies and free sites were blocked with $1 \%$ bovine serum albumin in PBS. Samples and standard dilution series were added for 2 hours. For measurement of BPI [16], human BPIspecific monoclonal antibody $4 \mathrm{E} 3$ was used for coating. Human recombinant BPI (kindly provided by M. Marra, Incyte, Palo Alto, CA) was used for standard titration curves. Washing and dilution buffers contained $80 \mathrm{mM}$ magnesium chloride to prevent disturbance by lipopolysaccharide. Biotinylated polyclonal rabbit anti-human BPI IgG was used as detection antibody. The detection limit for the BPI-assay was $200 \mathrm{pg} / \mathrm{ml}$.

For the IL-6 ELISA [17], plates were coated with the murine monoclonal antibody 5EI. Human rIL-6 (a kind gift from Prof. W. Sebald, PsychiologischChemisches Institut der Universität Würzburg, FRG) was used for standard titration curves. Biotinylated polyclonal rabbit anti-human IL-6 antiserum was used for detection. IL-6 could be detected with a lower limit of $10 \mathrm{pg} / \mathrm{ml}$. Polyclonal anti-human LBP IgG was used as coating for the LBP ELISA |18]. Human recombinant LBP (provided by M. Marra, Incyte) was used for standard 
titration curves. Washing and dilution buffers contained $40 \mathrm{mM}$ magnesium chloride to prevent disturbance by lipopolysaccharides. Detection occurred with a biotinylated polyclonal rabbit anti-human $\mathrm{LBP}$ IgG. The detection limit was $500 \mathrm{pg} / \mathrm{ml}$. Biotinylated antibodies were detected with peroxidaseconjugated streptavidin (Zymed, San Francisco, CA). Finally, 3,3'5,5'teiramethylbenzidine (Kirkegaard \& Perry Laboratories, Gaithersburg, MD) was used as a substrate. Photospectrometry $(450 \mathrm{~nm})$ was performed using a micro-ELISA autoreader. All plasma samples were analyzed in the same run.

C-reactive protein concentrations were measured preoperatively and at the first postoperative day using a turbidimetric method [19, 20]. A C-reactive protein reagent, in conjunction with the Synchron CX Systems CX CRP Calibrator Set (Beckman Instruments, Inc., Brea, CA, USA) was used for the quantitalive determination of $\mathrm{C}$-reactive protein in serum.

\section{Data analysis}

Repeated-measures ANOVA was used to compare changes in time between both patient groups. The Mann Whitney U-test was added, to isolate significant differences between both experimental groups at a single, predetermined timepoint. A Wilcoxon Matched-Pairs Signed-Ranks Test was used for comparisons of values from one variable between two timepoints. Incidence of variables was analyzed by the a $\chi^{2}$-test. Differences were considered significant at $p$-values less than 0.05 . All data are presented as mean \pm standard error of the mean (SEM).

\section{RESULTS}

Clinical characteristics

The intra-operative characteristics of both patient groups are shown in Table 1. The lower age and lower number of grafts in the NON-CPB group are explained by the fact that these patients had single vessel disease, which is usually seen at younger age. 
Table 1. Intra-operative characteristics of the two patient groups

\begin{tabular}{llll}
\hline & $\begin{array}{c}\text { CPB Group } \\
(\mathrm{n}=8)\end{array}$ & $\begin{array}{c}\text { NON-CPB Group } \\
(\mathrm{n}=8)\end{array}$ & p value \\
\hline Age (yrs.) & $65 \pm 4$ & $51 \pm 4$ & $<0.05$ \\
Height (Cm.) & $166 \pm 4$ & $172 \pm 3$ & $\mathrm{~ns}$ \\
Weight (kg.) & $78 \pm 3$ & $82 \pm 4$ & $\mathrm{~ns}$ \\
Sex (M/F) & $5 / 3$ & $4 / 4$ & $\mathrm{~ns}$ \\
Body surface area $\left(\mathrm{m}^{2}\right)$ & $1.86 \pm 0.05$ & $1.93 \pm 0.04$ & $\mathrm{~ns}$ \\
Smoking (N/Y) & $8 / 0$ & $6 / 2$ & $\mathrm{~ns}$ \\
Diabetes (N/Y) & $5 / 3$ & $7 / 4$ & $\mathrm{~ns}$ \\
Hyperlipidemia (N/Y) & $0 / 8$ & $0 / 8$ & $\mathrm{~ns}$ \\
CPB duration (min.) & $114 \pm 15$ & 0 & \\
ACC duration (min.) & $63 \pm 9$ & 0 & $<0.01$ \\
Number of grafts & $3.8 \pm 0.7$ & 1 & \\
\hline
\end{tabular}

Data are presented as mean \pm SEM. ACC, aortic cross-clamping. CPB, cardiopulmonary bypass. ns, non-significant.

\section{PMN activation}

Baseline levels of BPI were the same in both groups (Figure 1). BPI levels in the $\mathrm{CPB}$ group were elevated from the start of aortic clamping until the first postoperative day $(\mathrm{p}<0.05$ at all timepoints), reaching peak levels of 18 times baseline levels at the end of aortic clamping (data not shown).

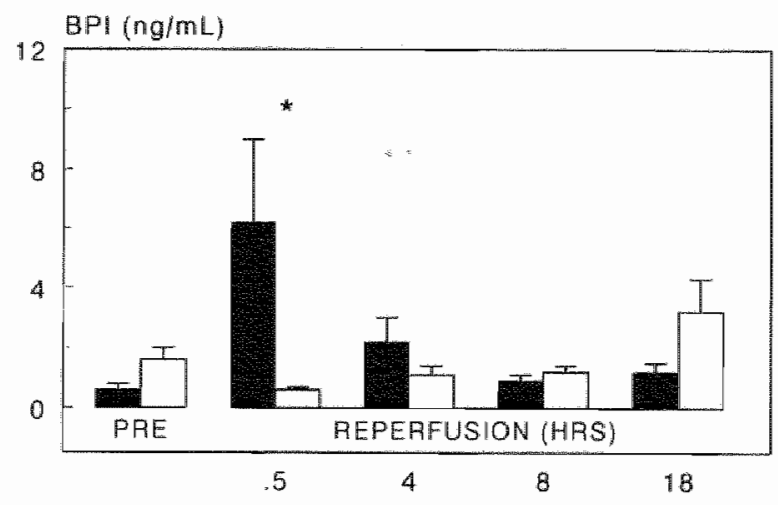

Figure 1. Mean plasma levels of $\mathrm{BPI}$ in patients undergoing CABG, either with (CPB group, filled bars) or without (NON-CPB group, open barsy the use of cardiopulmonary bypass. Data are presented as mean \pm SEM. indicates $p<0.05$, between groups. PRE, preoperative at induction. REPERFUSION (HAS), hours after the start of reperfusion. 
However, in the NON-CPB group, BPI levels showed mimimal changes during surgery and thereafter (Figure 1). At 0.5 hours after the start of reperfusion, BPI levels were significantly higher in the CPB group $(p<0.05)$.

\section{Acule phase response}

The acute phase response in both patient groups showed a characteristic pattern with a significant increase of $L B P$ and C-reactive protein preceded by an increase of IL-6 (Figure 2). Baseline levels of IL-6 were the same in both groups (Figure 2). In the CPB group, IL-6 levels decreased during CPB, subsequently increased and peaked at 4 hours after reperfusion (7.9 times higher than baseline levels) and remained elevated until the first postoperative day. In the NON-CPB group, $I L-6$ levels decreased during surgery and then peaked (5 times higher than baseline levels) at 8 hours after reperfusion. Although the $1 \mathrm{~L}-6$ response was the same in both groups (ANOVA for repeated measures showed no significant difference between both groups), the enhancement of IL-6 levels in plasma of NON-CPB patients was significantly delayed. At 0.5 and 4 hours after reperfusion, IL-6 levels were significantly higher in CPB patients (Mann Whitney U-test).

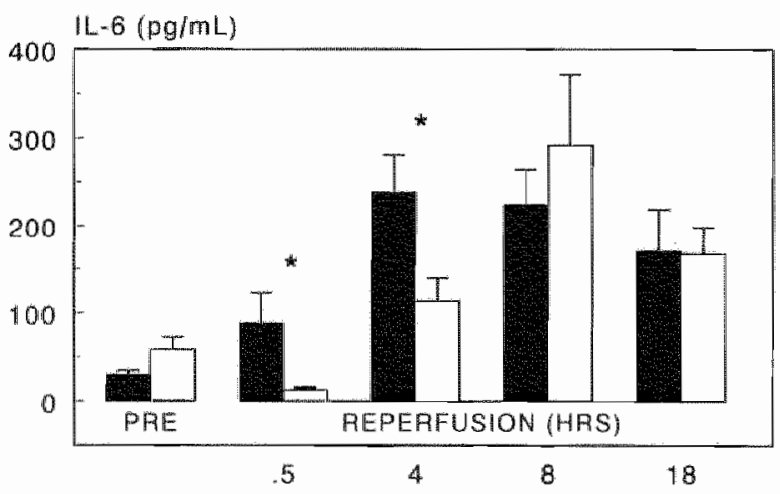

Figure 2. Mean plasma levels of $1 \mathrm{~L}-6$ in patients undergoing CABG, either with (CPB group, filled bars) or without (NON-CPB group, open bars) the use of cardiopulmonary bypass. Data are presented as mean \pm SEM. indicates $p<0.05$, between groups. PRE, preoperative at induction. REPERFUSION (HRS), hours after the start of repertusion. 
Mean preoperative plasma levels of LBP were $38.6 \pm 9 \mu \mathrm{g} / \mathrm{ml}$ in the CPB group, and $31.4 \pm 8 \mu \mathrm{g} / \mathrm{ml}$ in the NON-CPB group (Figure 3). LBP levels in both groups decreased early after start of reperfusion, and were increased on the first postoperative day. No significant differences were found between both groups at any timepoint.

Mean preoperative plasma levels of C-reactive protein were $17.4 \pm 7 \mathrm{mg} / \mathrm{L}$ and $7.1 \pm 1 \mathrm{mg} / \mathrm{L}$ in the CPB and NON-CPB group, respectively. At the first postoperative day, $\mathrm{C}$-reactive protein levels were significantly increased in both groups, to $79.3 \pm 8 \mathrm{mg} / \mathrm{L}$ in the CPB group, and $90.4 \pm 11 \mathrm{mg} / \mathrm{L}$ in the $\mathrm{NON}$ CPB group. No significant differences were found between both groups at either timepoint.

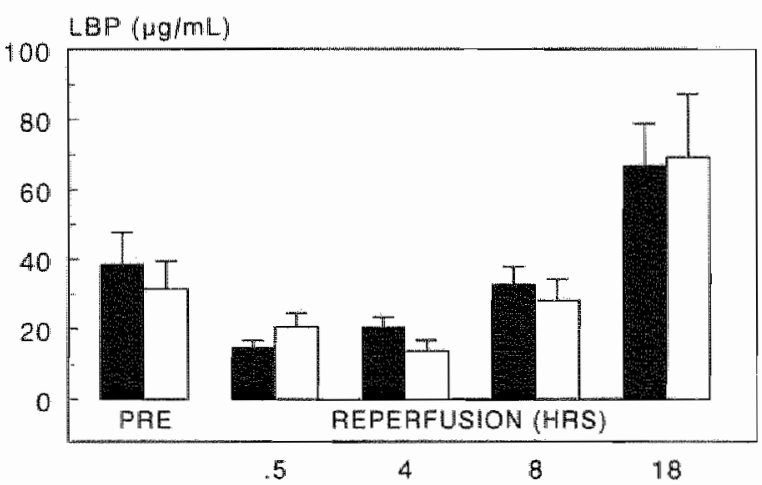

Figure 3. Mean plasma levels of LBP in patients undergoing CABG, either with (CPB group, filled bars) or without (NON-CPB group, open bars) the use of cardiopulmonary bypass. Data are presented as mean $\$$ SEM. PAE, preoperative at induction. FEPEFFUSION (HAS), hours atter the starl of repartusion.

\section{DISCUSSION}

Activation of PMNs and subsequent release of inflammatory mediators are well recognized during cardiac surgery with the use of CPB. Possible sites of leukocyte activation are complement activation via the classical pathway (e.g. heparin, surgery itself and protamine-heparin complexes) and the alternative pathway (e.g. blood-circuit contact), and the coagulation, kallikrein, and fibrinolytic cascades [6, 21-23]. Activation of PMNs leads to the release of oxygen metabolites, granular enzymes and arachidonic acid metabolites. Furthermore, endotoxins, released from the ischemic gut during $\mathrm{CPB}$, elicit the release of 
cytokines, such as TNFa and $\mathrm{L}_{-1}$, which lead to an inflammatory response. Also, ischemia-reperfusion is reported to trigger leukocyte activation. Reperfusion of the ischemic myocardiurn leads to retention of leukocytes within vessels and emigration of leukocytes into extravascular sites [21]. All these factors are supposed to contribute more or less to postoperative morbidity with sepsis-like symptoms. Recently, we showed that the use of heparin-coated extracorporeal circuits prevents the release of BPI in the early period after aortic unclamping, whereas the induction of LBP was unaffected [11]. Therefore, despite enhancements of the biocompatibility of the extracorporeal circuit, systemic inflammatory activation still exists in cardiac surgery. In the present study we studied the PMN response and acute phase response in patients undergoing $\mathrm{CABG}$ without the use of extracorporeal circulation and compared these data with a group of patients who had CABG with the use of extracorporeal circulation.

\section{PMN activation}

BPI is a human neutrophil granule protein which has been shown to bind to lipopolysaccharide and exerts both bactericidal effects upon gram negative bacteria and neutralizes lipopolysaccharide-activities. Dentener and colleagues [24] recently showed that the release of BPI and elastase, which are both stored in the azurophilic granule of PMN, is under similar regulatory control. Recently, we showed that BPI levels peak early after aortic unclamping [11]. As BPI is released after activation of PMN, it can be used as a marker of PMN activation. Gu and colleagues [25] reported an increase in elastase as soon as 5 minutes after release of the aortic crossclamp, and slowly decreasing elastase levels in the following half hour. In our present study, patients operated with $\mathrm{CPB}$ showed a significant increase in BPI levels during CPB. Early after aortic unclamping, BPI levels were decreased. Thus, the BPI levels found in our present study in CPB patients are in agreement with previous findings [25]. The PMN activation, shown by BPI levels, as seen in patients operated with $\mathrm{CPB}$ was absent in patients operated without $\mathrm{CPB}$. BPI levels in the NON-CPB patients did not increase during the early postoperative phase and were even significantly lower than baseline levels at 0.5 hours after start of reperfusion. Therefore, we conclude that PMN activation in patients undergoing coronary bypass with the use of CPB, is mainly caused by CPB related mechanisms. 


\section{Acute phase response}

Neutrophil and mononuclear phagocyte deriwed IL-6 is released in response to a variety of stimuli, including infection, major surgery and thermal injury [21]. IL-6 stimulates the adhesive interaction between neutrophils and cardiac myocytes [21], induces the acute phase response and therefore is a sensitive marker of the acute inflammatory response. CPB has been reported to stimulate the immediate release of IL-6 and subsequently anti-IL-6 therapy was suggested to prevent myocardial ischemia-reperfusion injury following $\mathrm{CPB}$ [21]. In agreement with previous studies [8], increased plasma IL-6 levels were observed in the present study in patients who underwent CABG with the use of CPB. However, although enhancement of IL-6 levels in the NON-CPB group was significantly delayed, the pattern of IL-6 release in patients who underwent $\mathrm{CABG}$ without the use of $\mathrm{CPB}$, was the same as in patients who underwent surgery with CPB. The earlier rise in IL-6 levels in the CPB group, was probably not associated with the elevated BPI levels early after reperfusion in these patients, since Dentener and colleagues [26] showed that BPI has an inhibitory effect on IL-6 release. The exact mechanisms involved in the delayed IL-6 release in the NON-CPB patients needs further investigation.

Levels of C-reactive protein and LBP, two acute phase proteins, were the same in both patient groups. C-reactive protein is one of the major acute phase reactants and acts as an opsonin for bacteria, parasites and immune complexes, and can activate the classical pathway of complement [27]. LBP facilitates binding of lipopolysaccharides to CD14 which leads to cell activation, and accelerates the elimination of lipopolysaccharides from the circulation via reconstituted high density lipoprotein [28]. IL-6 was also reported to be a valuable marker of tissue damage after abdominal surgery $[29,30]$. Results of our previous studies have shown that although leukocyte activation can be prevented by improving biocompatibility of the extracorporeal circuit, this does not affect the initiation of the acute phase response [1]]. Therefore, we conclude that it is mainly the surgical procedure and not the $\mathrm{CPB}$ procedure per se which triggers the development of the acute phase response. Furthermore, we conclude that the degree of PMN activation (BPI release) is not related to the degree of the subsequent acute phase response (IL-6, LBP, C-reactive protein release) in cardiac surgery patients, which is supported by the results of Cremer and colleagues [31].

In the present study, all patients were operated through median sternotomy resulting in similar surgical trauma for both groups. This enabled us to study the 
impact of the CPB procedure and associated factors (including hypothermic cardioplegia and heparin-protamine reversal) on the inflammatory response in $\mathrm{CABG}$ patients. Thus, we compared "classic" $\mathrm{CABG}$ patients with non-CPB $C A B G$ patients. Future studies need to focus on stepwise analysis of the influence of different aspects associated with the CPB procedure, e.g. hypothermia, cardioplegia, and heparin-protamine complexes, on the inflammatory response. However, the major finding in the present study was that, no matter what the underlying mechanisms are, patients who underwent CABG without the use of $\mathrm{CPB}$, showed an acute phase response which is similar to the response found in patients undergoing $\mathrm{CABG}$ with the use of $\mathrm{CPB}$.

The size of the present study population did not enable us to study the impact of $\mathrm{CPB}$ on postoperative performance. Therefore, larger study populations are needed to study the clinical relevance of our present findings.

In conclusion, our present study showed that the acute phase response found in coronary bypass surgery patients is a result of the surgical procedure (surgical trauma and/or anesthetics) rather than of the CPB procedure per se. However, the CPB procedure additionally initiates early PMN activation. Whether this activation is responsible for post bypass complications remains to be elucidated in future studies.

\section{REFERENCES}

1. Butler J. Rocker GM, Westaby S. Inflammatory response to cardiopulmonary bypass. Ann Thorac Surg 1993;55:552-9.

2. Westaby S. Organ dysfunction after cardiopulmonary bypass. A systemic inflammatory reaction by the extracorporeal circuit. Intensive Care Med 1987;13:89-95.

3. Gillinov AM, Bator JM, Zehr KJ, et al. Neutrophil adhesion molecule expression during cardiopumonary bypass with bubble and membrane oxygenators. Ann Thorac Surg $1993: 56: 847-53$.

4. Welbourn $\mathrm{CH}$, Goldman G, Paterson IS, et all. Pathaphysiology ischemia-reperfusion injury: central role of the neutrophil. Br U Surg 1991;78:651-5.

5. Andersen $L W$. Baek $L$, Degn $H$, et al. Presence of circulating endoloxins during cardiac operations. J Thorac Cardiovasc Surg 1987;93: 115-9.

6. Kirklini JK, Blackstone EH, Kirklin JW. Cardiopulmonary bypass: studies on its damaging effects. Blood Purification 1987:5:168-78.

7. Fosse $E$, Molnes TE, Ingvaldsen $B$. Complement actiwation during major operations with or without cardiopulmonary bypass. I Thorac Cardiovasc Surg 1987:93:860-6.

8. Steinberg JB, Kapelanski DP, Olson JD, et al. Cytokine and complement levels in patients undergoing cardiopulmonary bypass. of Thorac Cardiovasc Surg 1993:106: $1008-16$.

9. Harlan JM. Neutrophil-mediated vascular injury. Acta Med Scand [Suppl] 1987;715: $123-9$.

10. Weerwind PW, Maessen JG, van Tits $L J H$, et al. influence of Duraflo II heparin-treated extracorporeal circuits on the systemic inflammatory response in patients having 
coronary bypass. I Thorac Cardiovasc Surg 1995;110:1633-41.

11. Bouma MG. Maessen JG, Weerwind PW, at al. Release of LPS toxicily-modulating proteins in patients undergoing coronary bypass surgery using non-coated and heparincoated extra-corporeal circuits. Chest 1997;111:577-83.

12. Wison IC, Gardner TJ, DiNatale JM, al. Temporary leukocyte depletion reduces ventricular dystunction during prolonged postischemic reperfusion. I Thorac Cardiovasc Surg 1993:106:805-10.

13. Froon AHM, Greve JWM, Van der Lincen CJ, al al. Increased concentrations of cytokines and adhesion molecules in patients after repair of abdominal aortic aneurysm. Eur J Surg 1996:162:287-96.

14. Westaby S. Coronary surgery without cardiopulmonary bypass. Br Heart $\ 1995 ; 73: 203-5$.

15. Taylor KM. SIAS-The systemic inflammatory response syndrome after cardiac operations. Am Thorac Surg 1996;61:1607-8.

16. Dentener MA, Francol GJM. Smit FT, et al. Presence of bactericidall permeabilityincreasing protein in disease: detection by ELISA. J Infect Dis 1995;171:739-43.

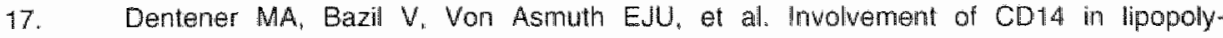
saccharide-induced tumor necrosis factor-a, IL-6 and IL-8 release by human monocytes and alveolar macrophages. J Immunol 1993:150:2885-91.

18. Froon AHM, Dentener MA. Greve JWM, et al. Lipopolysaccharide toxicity-regulating proteins in bacteremia. Infect Dis 1995;171:1250-7.

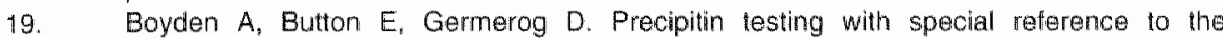
measurement of turbidity. $J$ immunol 1947:57:211.

20. Hellsing $K_{*}$. The effecis of different polymers for enhancement of the antigen-antibody reaction as measured with nephelometry. Protides of the Biological Fluids 1973:23:579.

21. Holzheimer $R G$, Molloy $R G$, Görlach $H$, at al. IL-6 and TNF releatse in association with neutrophil activation after cardiopulmonary bypass surgery. Infection 1994:22:37-4:2.

22. Kirklin JKK, Chenoweth DE, Naftel DC, et al. Effects of protamine administration after cardiopulmonary bypass on complement, blood elements, and the hemodynamic state. Ann Thorac Surg 1986;41:193-9.

23. Kalfin RE, Engelman RM, Fousou JA, et al. Induction of interleukin-8 expression during cardiopulmonary bypass. Circulation 1993;88:401-6.

24. Dentener MA, Francot GJM, Hiemstra PS, et al. Bactericidal/ permeability-increasing protein release in whole blood ex vivo: strong induction by lipopolysaccharide and tumor mecrosis factor-alpha. J Infect Dis 1997;175:108-17.

25. Gu YJ, Van Deveren W, Boonstra PW, et al. Leukocyte activation with increased expression of CR3 receptors during cardiopumonary bypass. Ann Thorac Surg 1992;53; 839-43.

26. Dentener MA, von Asmuth EJU. Francot GJM ef al. Amtagonistic effects of lipopolya saccharide binding protein and bactericidal/permeability-increasing protein lipopolysackcharide-induced cytokine release by mononuclear phagocytes. Competition for binding to lipopolysaccharide. J Irmmunol 1993;151:4258-65.

27. Steel DM, Whitehead AS. The major acute phase reactants: C-reactive protein "senum amyloid $P$ component and serum amylod A proteim. Immunol Today 1994; 15:81-8.

28. Wurfel MM, Halman E. Wright S. Soluble CD14 acts as a shutte in reutralization of lipopolysaccaride (LPS) by LPS-binding protein and reconstituted high density lipoprotein. $J$ Exp Med 1995;1181:1743-54.

29. Shenkin $A_{n}$ Fraser WD, Series $J$, et al. The serum interleukin 6 response to elective surgery. Lymphokine Fes 1989,8:123-7.

30. Cruickshank. AM, Fraser WD, Burns HJ, et al. Response of serum interleukin 6 in patients undergoing elective surgery of varying severity. Clin Sci Colch 1990,79:161-5.

31. Cremer $J$, Martin $M$, Redl $H$ et al. Systemic inflammatory response syndrome after cardiac operations. Ann Thorac Surg 1996;61:1714-20. 

CHAPTER 3

Impact of blood transfusions on inflammatory mediator release in patients undergoing cardiac surgery

Abstract was winner of the ACCP Young Investigator Award. CHEST 98, The XIX World Congress on Diseases of the Chest, November 8-12, 1998, Toronto. Canada.

In press, Chest 


\section{ABSTRACT}

Purpose. This study investigates the effects of packed red cells (PC) transfusion during cardiac surgery on the release of pro-inflammatory mediators.

Methods. In 1]4 consecutive patients we evaluated systemic inflammation by measuring bactericidal permeability increasing protein (BPI) as a marker of neutrophil activation, interleukin-6 (IL-6), lipopolysaccharide binding protein (LBP) and C-reactive protein (CRP) at several timepoints from time of induction of anesthesia until the first postoperative day. Concentrations of these mediators, except CRP, were also measured in PC.

Results. 36 patients received PC intra-operatively. BPI and LBP were present in all units of packed red cells tested. In none of the packed red cells IL-6 could be detected. BPI and IL-6 levels were significantly higher in transfused patients than in non-transfused patients at 0.5 and 4 hours, and at $0.5,4$ and 18 hours after reperfusion, respectively. Furthermore, BPI plasma levels increased with the number of units of blood administered. In contrast, plasma levels of LBP and $\mathrm{C}$-reactive protein were similar in both patient groups. Transfused patients had a significantly longer time until extubation ( $42 \pm 12$ vs. $22 \pm 2$ hours), stay at the cardiosurgical intensive care unit $(89 \pm 21$ vs. $45 \pm 6$ hours), and postoperative hospitalization ( $10.6 \pm 1.6 \mathrm{vs} .7 .2 \pm 0.4$ days) than control patients.

Conclusions. These data indicate that intra-operative red blood cell transfusions do contribute to the inflammatory response following cardiac surgery both by enhancing part of the response and possibly by directly changing plasma concentrations of inflammatory mediators. Furthermore, these data show that intra-operative PC transfusion is associated with a worse postoperative perfomance.

\section{INTRODUCTION}

In previous studies $[1,2]$, we showed that the extent of the systemic inflammatory response to cardiac surgery is not primarily determined by the cardiopulmonary bypass procedure. Other factors, such as intrinsic patient factors and intra-operative trauma, also play a role in determining the extent of the inflammatory response. In the present study we present data on the impact of the administration of routinely used allogeneic blood transfusions during cardiac surgery on plasma levels of circulating inflammatory mediators. The administration of allogeneic blood transfusions is common use in cardiac 
surgery. However, along with its beneficial effects, allogeneic blood transfusions have been reported to suppress the immune system, thereby contributing to patient morbidity during recovery $[3,4]$.

Based on previous studies [5], we hypothesized that the plasma supematant of allogeneic packed red cells contains bioreactive substances and that administration of packed red cells during cardiac surgery, causes an enhanced inflammatory reaction which in turn is reflected by enhanced plasma levels of inflammatory mediators and increased postoperative morbidity.

The aim of the present study was to determine to which extent intraoperative allogeneic blood transfusions affect the release of inflammatory mediators in cardiac surgery patients. In addition, we examined the correlation of intra-operative red blood cell transfusion and patient morbidity during postoperative recovery.

For this, we measured bactericidal permeability increasing protein (BPI) levels as a marker of activation of polymorphonuclear leucocytes (PMN), interleukin-6 (IL-6), and the acute phase proteins lipopolysaccharide binding protein (LBP), and C-reactive protein (CRP) in 114 patients undergoing cardiac surgery, of whom 36 received at least one allogeneic packed red cells unit during surgery. Furthermore, we checked for the presence of BPI, IL-6 and LBP in packed red cells that were administered to these patients.

\section{MATERIALS AND METHODS}

\section{Patients}

A total of one hundred and fourteen consecutive adult patients undergoing coronary artery bypass grafting (CABG) and/or valve surgery with cardiopulmonary bypass were enrolled. Age boundaries were set at 30 and 80 years. Patients with current infection, hematologic or endocrinologic disease, or a history of organ transplantation or blood transfusions were excluded. Retrospectively, this cohort was analyzed and divided in two groups, those who received allogeneic packed red cells intra-operatively, and those who did not. All subjects gave written informed consent for the study that was approved by the local ethical and research council. 
Intra-operative patient management

Standard anesthetic (lorazepam, fentanyl citrate, sufentanil citrate, alfentanil hydrochloride, midazolam hydrochloride, pancuronium bromide) and monitoring techniques (electrocardiogram, arterial pressure monitoring, urinary output, rectal and skin temperature monitoring) were used in all patients. Cefuroxim was used for antibiotic prophylaxis, the first dose was admini-stered before sternotomy.

Before connection to the non-heparin coated extracorporeal circuit for cardiopulmonary bypass, porcine heparin $(300 \mathrm{IU} / \mathrm{kg}$, Heparin Leo, Leo Pharmaceutical Products BV, Weesp, The Netherlands) was administered in order to achieve an activated coagulation time $>480 \mathrm{~s}$ (Hemochron 400 , International Technidyne Corp., NJ). Details of the extracorporeal circulation circuit and perfusion procedures have been published previously [6]. After initiation of $\mathrm{CPB}$, and after reaching a blood temperature below $28^{\circ} \mathrm{C}$, the heart was topically cooled with cold saline $(0.9 \%)$ at $4^{\circ} \mathrm{C}$. When fibrillation occurred, the aorta was cross-clamped and a single dose of approximately $800 \mathrm{ml}(600-1000$ $\mathrm{ml}$ ) of St.Thomas-I cardioplegic solution at $4^{\circ} \mathrm{C}$ was infused into the aortic root over a period of 4 minutes (3-5 minutes) to provide myocardial preservation. Hypothermic pulsatile perfusion was maintained throughout the period of aorta cross-clamping. After completion of all distal anastomoses, the aortic crossclamp was removed and proximal anastomoses were performed with a partial occlusion clamp after spontaneous or electrical defibrillation. Meanwhile the rewarming of the patient to $37^{\circ} \mathrm{C}$ continued. Heparin was neutralized by 3 $\mathrm{mg} / \mathrm{kg}$ protamine chloride (Hoffman/Laroche B.V., Mijdrecht, The Netherlands). All pump blood, including shed blood, was returned to the patient without hemoconcentration through the aortic cannula or intravenously via infusion bags. Allogeneic blood transfusions were administered if hematocrit values were below 20 volume percent in coronary artery bypass grafting patients or below 25 volume percent in valve surgery patients (in both cases in combination with the measured intra-operative blood loss or the extent of hemodilution). Patients received standard (leukocyte-containing, buffy coatfree) saline-adenine-glucose-mannitol (SAG-M) red blood cells (Dutch Red Cross Bloodbank Zuid-Limburg, Maastricht, The Netherlands), $325 \mathrm{~mL} / \mathrm{unit}$, hematocrit 60 volume percent. Red blood cell units contained $<5 \times 10^{8} /$ unit leukocytes and $<15 \times 10^{9}$ thrombocytes/unit. Red blood cell units were stored at $4^{\circ} \mathrm{C}$. Postoperative patient treatment in the cardiosurgical care unit was standardized and similar for both groups. All packed red cells were administered 
before the final intra-operative blood sample was taken, e.g. within 0.5 hours after the release of the aortic cross-clamp.

\section{Blood sampling}

Blood samples were taken upon induction of anesthesia (baseline), at the start of aortic cross-clamping, at the start of reperfusion and $0.5,4,8$ and 18 hours thereafter. Samples were collected in evacuated blood collection tubes $(10 \mathrm{ML}$, Monoject, Sherwood Medical, Ballymoney, N. Ireland) containing ethylenediamine-tetra-acetic acid. Immediately after sampling, the blood was cooled, centrifuged at $3500 \mathrm{rpm}$ for 20 minutes and plasma samples were stored at $-70^{\circ}$ $\mathrm{C}$ until measurements.

For measurement of inflammatory mediators in the units of allogeneic packed red cells, we randomly selected 12 units of packed red cells. Samples were collected in evacuated blood collection tubes ( $5 \mathrm{ML}$, Monoject) containing ethylene-diamine-tetra-acetic acid. Samples were collected directly from the infusion bag in case packed red cells were included in the priming volume of the heart-lung machine, or at bedside just before infusion from a routinely used ramp of 4 one-way stopcocks (Vygon, Ecouen, France), after which the samples were treated as described above for the plasma samples.

\section{Measurements}

Plasma levels of BPI, IL-6 and LBP were measured using sandwich enzymelinked immunosorbent assays (ELISA), which have been described elsewhere 17-9]. In short, 96-well plates (Immuno-Maxisorp; Nunc, Roskilde, Denmark) were coated with the appropriate antibodies. For BPI, IL-6 and LBP measurements, human BPI-specific monoclonal antibody $4 \mathrm{E} 3$, murine monoclonal antibody $5 E 1$, and polyclonal anti-human LBP IgG was used as coating, respectively. Free sites were blocked with $1 \%$ bovine serum albumin in PBS. Samples and standard dilution series were added for 2 hours. Human recombinant BPI (kindly provided by M. Marra, Incyte, Palo Alto, CA), human rlL-6 (a kind gift from Prof. W. Sebald, Psychiologisch-Chemisches Institut der Universität Würzburg, Germany), and human recombinant LBP were used for standard titration curves. Human recombinant LBP was obtained from supernatant of CHO cells transfected with cDNA of human LBP (kindly provided by Dr. P.

Tobias, Scripps Research Institute, La Jolla, CA). In case of the BPI and LBP ELISA, washing and dilution buffers contained $80 \mathrm{mM}$ or $40 \mathrm{mM}$ magnesium 
chloride to prevent disturbance by lipopolysaccharide, respectively. Biotinylated polyclonal rabbit anti-human BPI $\operatorname{IgG}$, biotinylated polyclonal rabbit antibuman IL-6 antiserum, and polyclonal rabbit anti-human LBP IgG were used as detection antibodies. The detection limits for the ELISA's were $200 \mathrm{pg} / \mathrm{mL}$ for the BPI-assay, $10 \mathrm{pg} / \mathrm{mL}$ for $\mathrm{IL}-6$, and $500 \mathrm{pg} / \mathrm{ml}$ for LBP. Biotinylated antibodies were detected with peroxidase-conjugated streptavidin (Zymed, San Francisco, CA). Finally, 3,3'5,5'-tetramethylbenzidine (TMB; Kirkegaard \& Perry Laboratories, Gaithersburg, MD) was used as a substrate. Photospectrometry $(450 \mathrm{~nm})$ was performed using a micro-ELISA autoreader. All plasma samples were analyzed in the same run.

CRP concentrations were measured using a turbidimetric method. A CRP reagent (Beckman test kit number 445855), in conjunction with the Synchron CX Systems CX CRP Calibrator Set (Beckman, number 445915) (Beckman Instruments, Inc, Brea, CA) was used for the quantitative determination of CRP in serum. CRP levels were determined at the day before surgery, and at days 1 , 2,4 and 6 after surgery.

\section{Clinical data}

The following variables were recorded: type of surgery, time until weaning from ventilation, postoperative stay in the intensive care unit, diuresis during the first 24 postoperative hours, total mediastinal fluid drainage, length of postoperative hospitalization, incidence of postoperative infection during hospitalization, and mortality. CDC definitions for nosocomial infections were used for diagnosing postoperative infections [10]. All infections were diagnosed during hospitalization.

\section{Data analysis}

Repeated-measures ANOVA was used to compare changes in time between both patient groups. The Mann Whitney U-test was added, to isolate significant differences between both experimental groups at a single, predetermined timepoint. A Wilcoxon Matched-Pairs Signed-Ranks Test was used for comparisons of values from one variable between two timepoints. Incidence of variables was analyzed by a $\chi^{2}$-test. Independent predictive value of parameters was assessed by multiple regression analysis. Differences were considered significant at p-values less than 0.05 . All data are presented as mean \pm standard error of the mean (SEM). 


\section{RESULTS}

\section{Clinical characteristics}

The intra-operative characteristics of both patient groups are shown in Table $\mathbb{I}$. From the total group of 114 patients, 36 patients received packed red blood cells

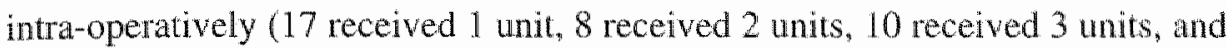
1. patient received 4 units of packed red blood cells).

Tablle 1. Intra-operative characteristics of the two patient groups

\begin{tabular}{llll}
\hline & $\begin{array}{l}\text { Controls } \\
(n=78)\end{array}$ & $\begin{array}{c}\text { PC Group } \\
(n=36)\end{array}$ & $p$ value \\
\hline Age $(y)$ & $61 \pm 1(39-75)$ & $67 \pm 1(42-77)$ & $<0.05$ \\
Height $(\mathrm{cm})$ & $172 \pm 1(150-190)$ & $165 \pm 1(150-185)$ & $<0.05$ \\
Weight $(\mathrm{kg})$ & $80 \pm 1(52-121)$ & $72 \pm 2(50-99)$ & $<0.05$ \\
Male/Female & $67 / 11$ & $13 / 23$ & $<0.05$ \\
Type of surgery: & & & $\mathrm{ns}$ \\
$\quad$ CABG & $69(88.5 \%)$ & $27(75 \%)$ & $\mathrm{ns}$ \\
$\quad$ Valve & $6(7.7 \%)$ & $6(16.7 \%)$ & $\mathrm{ns}$ \\
$\quad$ CABG + valve & $3(3.8 \%)$ & $3(8.3 \%)$ & $\mathrm{ns}$ \\
CPB duration (min) & $90 \pm 4(36-205)$ & $102 \pm 6(53-193)$ & $\mathrm{ns}$ \\
ACC duration (min) & $59 \pm 3(21-146)$ & $66 \pm 5(8-142)$ & \\
\hline
\end{tabular}

Data are presented as mean \pm SEM. ACC, aortic cross-clamping. CPB, cardiopulmonary bypass. ns, non-significant. $P C$, packed red blood cells.

\section{Clinical data}

Preoperative hematocrit values and hemoglobin levels were significantly lower in the transfusion group than in the control group, $32 \pm 6$ vs. $38 \pm 4$ volume percent $(p<0.001)$, and $7.2 \pm 0.1$ vs. $8.5 \pm 0.1 \mathrm{mmol} / \mathrm{L}(\mathrm{p}<0.001)$, respec-tively. Hematocrit values and hemoglobin levels decreased postoperatively without alterations between both patient groups. At the first postoperative day, hematocrit values and hemoglobin levels were $29 \pm 4 \%$ and $6.2 \pm 0.1 \mathrm{mmol} / \mathrm{L}$ in the transfusion group, and $30 \pm 3 \%$ and $6.3 \pm 0.1 \mathrm{mmol} / \mathrm{L}$ in the control group (not significant). 
Time until weaning from ventilation was significantly longer in transfused patients than in controls: $42 \pm 12$ vs. $22 \pm 2$ hours (Table 2). Furthermore, postoperative length of stay on the cardiosurgical intensive care unit until transportation to the ward was significantly longer in transfused patients (Table 2).

Postoperative mediastinal bleeding and postoperative diuresis during the first 24 postoperative hours did not significantly differ between both groups (Table 2). The incidence of postoperative infections in controls and in transfused patients was not significantly different. However, duration of postoperative hospitalization was significantly longer in transfused patients than in control patients (Table 2).

Table 2. Parameters of postoperative performance of the two patient groups

\begin{tabular}{llll}
\hline & $\begin{array}{c}\text { Controls } \\
(n=78)\end{array}$ & $\begin{array}{c}\text { PC Group } \\
(\mathrm{n}=36)\end{array}$ & $\rho$ Value \\
\hline Time until extubation (hrs) & $22 \pm 2$ & $42 \pm 12$ & $<0.025$ \\
Time until transport to the ward (hrs) & $45 \pm 6$ & $89 \pm 21$ & $<0.025$ \\
Diuresis 24 hours postoperatively (m)) & $2362 \pm 108$ & $2144 \pm 159$ & $n s$ \\
Postoperative mediastinal bleeding $(\mathrm{ml})$ & $1358 \pm 92$ & $1272 \pm 112$ & $n s$ \\
Incidence postoperative infections $(\%)$ & 10.3 & 19.4 & 0.17 \\
Postoperative hospitalization (days) & $7.2 \pm 0.4$ & $10.6 \pm 1.6$ & $<0.01$ \\
\hline
\end{tabular}

ns, non-significant. PC, packed red blood cells.

\section{Inflammatory mediators}

In order to study neutrophil activation, BPI plasma levels were measured. Baseline levels of BPI were similar in both groups and were raised from the start of aortic clamping until the first postoperative day $(\mathrm{p}<0.05$ at all timepoints) (Figure 1). Peak levels of 8 times baseline levels were reached at the end of aortic clamping in controls, and 17 times baseline levels in transfused patients. At 0.5 and 4 hours after start of reperfusion, BPI levels were significantly higher in transfused patients $(\mathrm{p}<0.01)$.

In order to study the acute phase response, IL-6 LBP and CRP were measured. Baseline levels of IL- 6 were similar in both groups, $0.07 \pm 0.01$ vs. $0.09 \pm 0.03 \mathrm{ng} / \mathrm{mL}$ (Figure 2). In the control group, IL-6 levels decreased during $\mathrm{CPB}$, subsequently increased and peaked at 8 hours after reperfusion (6 times above baseline levels) and remained elevated until the first postoperative day. 


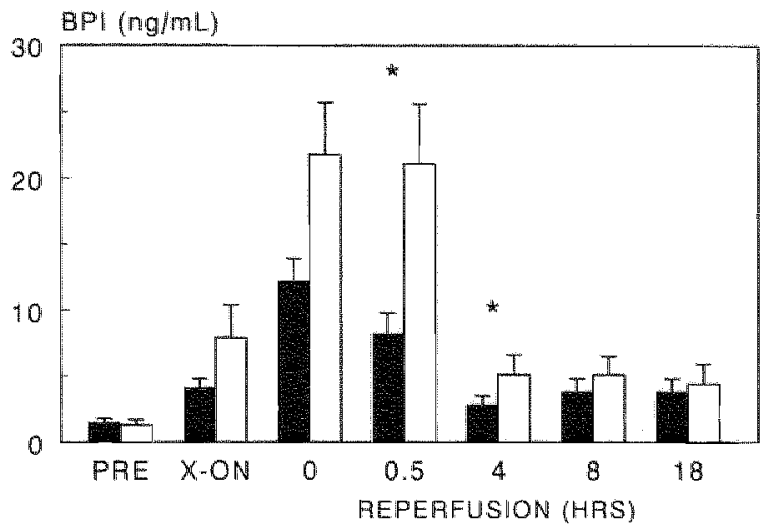

Figure 1. Mean plasma levels of BPI in in patients undergoing cardiac surgery, either receiving no packed red cells during surgery (filled bars) or receiving at least one unit of packed red cells (open bars). Data are presented as mean $\pm S E M$. " indicates $p<0.05$, between groups. P.AE, preoperative at induction. $X$-ON, start of aortic cross-clampling. REPERFUSION (MRS), hours after the stiant of reperfusion.

In the transfusion group, IL-6 levels increased from the start of reperfusion and peaked at 4 hours after reperfusion ( 9 times higher than baseline levels).

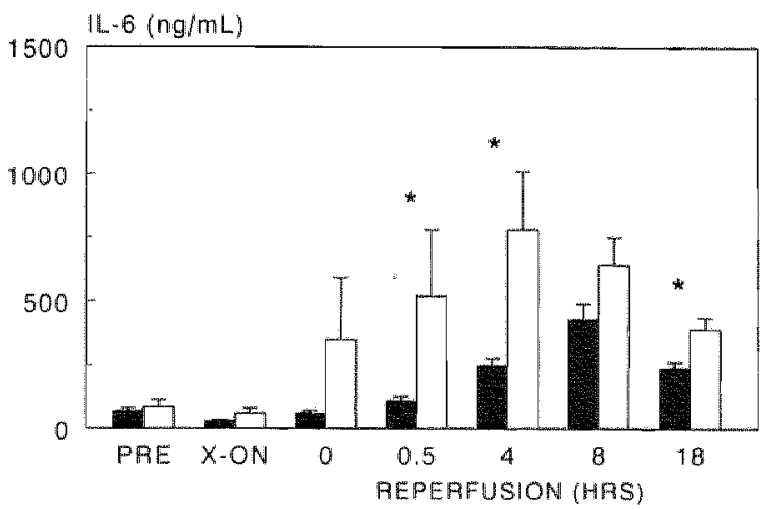

Figure 2. Mean plasma levels of 14.6 in patents undergoing cardac sungery, either receiwing no packed red cells during suigery flilled bars) or reciving at least one unit of packed red colls (open bars). Data are presented as mear \pm SEM. indicates $p<0.05$. between groups. PAE. preoperative at induction. $X$-On, start of aortic cross-clamping. REPEAFUSION (MRS), hours after the start of reperfusion. 
The IL-6 response was significantly different between both groups (ANOVA for repeated measures, $p<0.05$ ), i.e. maximum plasma levels of IL-6 were reached earlier in transfused patients. Also, at $0.5,4$ and 18 hours after reperfusion, IL 6 levels were significantly higher in transfused patients $(p<0.05)$.

Mean preoperative plasma levels of the acute phase protein LBP were $32.4 \pm$ $4 \mu \mathrm{g} / \mathrm{mL}$ and $40.0 \pm 5 \mu \mathrm{g} / \mathrm{mL}$ in the control group and transfusion group, respectively (Figure 3 ). In both groups, LBP plasma levels decreased during surgery (until 0.5 hours after reperfusion $)(p<0.01)$, and gradually increased between 0.5 and 18 hours after reperfusion $(p<0.01)$.

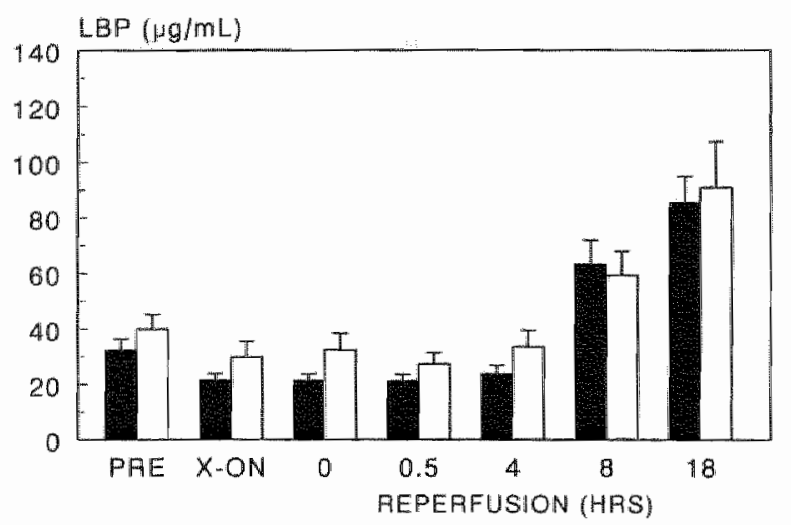

Figure 3. Mean plasma levels of LBP in patients undergoing cardiac surgery, either receiving no packed red cells during surgery (tilled bars) or receiving at least one unit of packed red cells (open bars). Data are presented as mean \pm SEM. PRE, preoperative at induction. $x \times$ ON, start of aortic cross-clamping. PEPER-FUSION (HAS), hours after the start of repertusion.

Mean preoperative plasma levels of CRP were $11.5 \pm 3 \mathrm{mg} / \mathrm{L}$ and $12.1 \pm 4$ $\mathrm{mg} / \mathrm{L}$ in the control group and transfusion group, respectively (Figure 4). At the first postoperative day, CRP levels were significantly increased in both groups, to $86.9 \pm 3 \mathrm{mg} / \mathrm{L}$ in the control group, and $82.6 \pm 7 \mathrm{mg} / \mathrm{L}$ in the transfusion group. CRP levels reached highest mean plasma levels at day 2 after surgery and gradually decreased thereafter. All postoperative CRP levels were significantly elevated from baseline levels $(p<0.01)$. Both LBP and CRP levels did not significantly differ between both patient groups at any timepoint. 


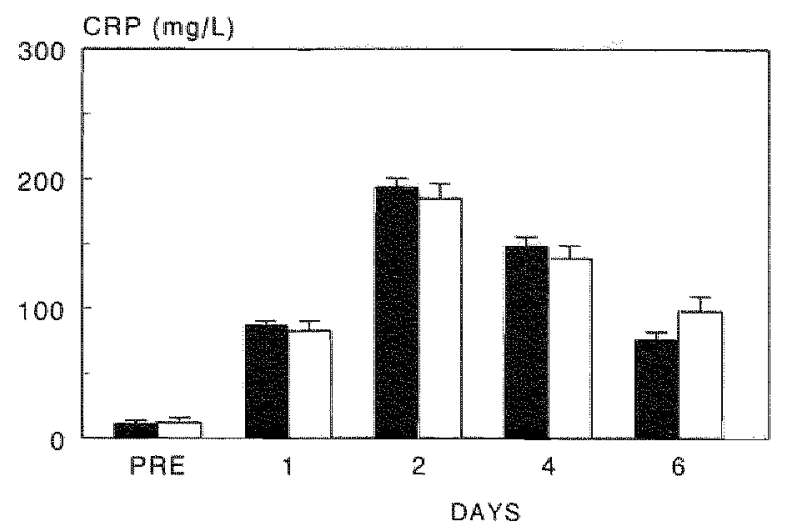

Figure 4. Mean plasma levels of CRP in patients undergoing cardiac surgery, either receiving mo packed red cells during surgery (illed bars) or receiving at least one unit of packed ned cells (open bars). Data are presented as mean \pm SEM. PRE, day before surgery. DAYS, days after surgery.

Inflammatory mediators in the packed red cell units

In order to determine whether substances in the packed red cells affect inflammatory mediator release in the recipient, BPI, IL-6, and LBP were measured in the packed red cells units. The allogeneic packed red cell units contained an average of $21.55 \pm 4.9 \mathrm{ng} / \mathrm{mL}$ BPI (range $4.56-50 \mathrm{ng} / \mathrm{mL}$ ), and $600.5 \pm 66 \mathrm{ng} / \mathrm{mL} \mathrm{LBP}$ (range $271-900 \mathrm{ng} / \mathrm{mL}$ ). In contrast, no IL-6 could be detected in any of the packed red cells. BPI levels, but not LBP levels, progressively increased over storage time. In packed red cell units with an age of 2 days BPI levels averaged approximately $10 \mathrm{ng} / \mathrm{mL}$, whereas in packed red cell units of 31 days of age BPI levels were approximately $50 \mathrm{ng} / \mathrm{mL}$, suggesting desintegration of PMN present in the packed cells.

Analysis of risk factors for red cell transfusion and postoperative morbidity

Using retrospective group stratification, we found significant differences between control patients and transfused patients with respect to age, height, weight, the distribution of gender (Table 1), preoperative hematocrit, and preoperative hemoglobin levels. A stepwise multiple regression analysis including 
these parameters as independent wariables and the administration of packed red cells during surgery as dependent variable, revealed, as expected, that preoperative hematocrit and hemoglobin levels are key determining factors in intra-operative packed red blood cell transfusion requirements $(p<0.001$ and $p=0.023$ for hematocrit and hemoglobin, respectively). Furthermore, entering age, height, weight, gender, and the intra-operative administration of packed red cells as independent variables and postoperative BPI or IL-6 levels as dependent variables, showed that the intra-operative administration of packed red cells during surgery was the most important predictor of BPI levels at aortic unclamping $(p=0.009)$ and 0.5 hours thereafter $(p=0.002)$, and IL-6 levels at 0.5 $(p=0.025)$ and 4 hours after aortic unclamping $(p=0.002)$. In addition, entering age, gender, and the intra-operative administration of packed red cells as independent variables and time until weaning from ventilation or postoperative stay in the intensive care unit as dependent variable revealed that in both cases the intra-operative administration of packed red cells was the most important independent variable predicting time until weaning from ventilation $(\mathrm{p}=0.022)$ and postoperative stay in the intensive care unit $(p=0.011)$. Therefore, despite the differences in some preoperative variables, the intra-operative administration of packed red cells during cardiac surgery is found to be significantly associated with the release of inflammatory mediators BPI and IL-6, and to coincide with impaired postoperative performance.

\section{DISCUSSION}

This study provides evidence that the well-known inflammatory response to cardiac surgery, which historically has been attributed to the cardiopulmonary bypass procedure, is strongly affected by the administration of packed red cells during surgery.

In the present study we measured BPI in plasma from patients as well as in packed red cell units to evaluate whether cells from this human neutrophil granule protein that originate from transfusion units affect the presence of inflammatory mediators found in the recipient. To this end BPI was measured in plasma from patients as well as in packed red ceil units. BPI is a human neutrophil granule proteins which has been shown to bind to LPS and both exerts bactericidal effects on gram negative bacteria and neutralizes LPSactivities [1]. In plasma, BPI is released after activation of PMN, and therefore can be used as a marker of PMN activation. In the packed red cell units, large 
amounts of BPI may be released from the azurophilic granules due to PMN activation by the plastic infusion bag or PMN desintegration as a result of cold storage $\left(4^{\circ} \mathrm{C}\right)[11]$.

Inflammatory mediator release

In our study we showed a perioperative increase in BPI plasma levels which was identical to levels that we found in previous studies $[1,12]$, with higher levels at 0.5 and 4 hours after aortic unclamping in transfused patients $(p<0.05)$. In addition, BPI was present in all packed red cells with higher levels in units that had been stored longer. These data suggest that part of the higher BPI levels at 0.5 and 4 hours after aortic unclamping in the intra-operatively transfused patients may originate from the transfusion units. Indeed, calculations revealed that in patients receiving 2 units of packed red cells, approximately $15 \%$ of the total amount of BPI in plasma at 0.5 hours after aortic unclamping can originate from the transfusion products (based on an estimated plasma volume of 4500 $\mathrm{mL}$ ). Alternatively, the BPI increase can be explained by either donor on recipient leukocytes becoming activated upon transfusion.

Several studies have shown that leukocytes present in allogeneic cellulan blood components are associated with adverse effects to the recipient $[3,13]$. The proposed immune suppressive effects of donor leukocytes might be beneficial for some patients, e.g. for the maintenance of kidney allografts [13], in patients undergoing cardiac surgery, however, these effects may be undesirable since these patients are already immune suppressed by the surgical trauma. Although it is generally assumed that these effects are caused by the interaction of antileukocyte alloantibodies in the recipients" plasma and white cells in the transfusion product, Heddle and colleagues [5] recently reported that nonidentified bioreactive substances in the plasma supernatant produced or released by platelet products mediate reactions upon transfusion [5]. Our present data are in support of this view as they confirm the presence of large amounts of BPI in packed red cells. The transfusion of BPI by giving packed red cells to a patient actually leads to increased circulating plasma levels of BPI. It cannot be deduced from our present data that higher BPI levels cause an increased postoperative morbidity. 
In agreement with previous studies $[1,14]$, in the present study increased plasma IL-6 levels were observed in all patients. Neutrophil and mononuclear phagocyte derived interleukin-6 is released in response to a variety of stimuli, including infection, major surgery and thermal injury [15]. IL-6 is a pleiotropic cytokine that stimulates the adhesive interaction between neutrophils and cardiac myocytes, induces the acute phase response and therefore is a sensitive marker of the inflammatory response. In this study, the enhancement of IL-6 levels in control patients was significantly delayed and also lower compared to transfused patients, although the pattern of IL-6 release was similar in both patient groups. Unlike BPI, we did not detect IL-6 in packed red cell units, which is in agreement with findings by others [16]. Interestingly, IL-6 was found by several authors in stored platelet concentrates [5, 17-19]. Heddle and colleagues found low concentrations of $\mathrm{IL}-6$, even when the concentrate was filtered before storage to remove contaminating leukocytes [5]. In addition, they showed that IL-6 levels in the platelet concentrates progressively increased during storage and positively correlated with the leukocyte count in the platelet product. Importantly, in their study, the platelet concentrates were stored at $22^{\circ}$ $\mathrm{C}$ ( $v s .4^{\circ} \mathrm{C}$ for the packed red cells in our study), which may have affected the production and release of IL-6 in these concentrates. Although others reported that the production of pro-inflammatory cytokines is one of the immune functions which is depressed by allogeneic blood transfusions [20], the findings of the present study suggest that the significantly higher IL-6 plasma levels in the transfused patients result from an increased IL-6 release by the recipient. Whether this increased IL-6 release is induced by substances in stored blood has yet to be established.

Plasma levels of CRP and LBP, two acute phase proteins, were similar in both patient groups. CRP is the prototypal acute phase reactant, and can activate the classical pathway of complement [21]. Our data support the acute phase nature of the LBP response as well as the CRP response. Since LBP is produced by hepatocytes, and was found in all packed red cell units, the LBP in these units probably originates from the donor, and is not produced or released during cold storage. This finding is supported by the fact that, unlike BPI levels, LBP levels did not increase with the length of storage. LBP levels in the packed red cell units were low compared to LBP plasma levels and presumably did not substantially affect plasma levels (Figure 3).

Interestingly, the rise of LBP and CRP in the systemic circulation was iden- 
tical in both study groups, despite the fact that we found significant differences in plasma cytokine levels (Figure 2). Thus, the present data suggest that in patients undergoing cardiac surgery, the amount of circulating IL-6 in the systemic circulation does not necessarily reflect the amount of acute phase proteins produced $[21,22]$.

\section{Patient morbidity}

In patients undergoing cardiac surgery, the surgical trauma induces a noninfectious systemic inflammatory response, which is considered to play a role in the development of postoperative complications [23]. Thus, in patients receiving allogeneic packed red cells, bioreactive substances might serve as a second inflammatory insult, which amplifies the initial inflammatory response. This results in a further imbalance between pro-inflammatory and counterregulatory influences, which may lead to damage of otherwise healthy cells and organs, and thus leads to an impaired postoperative recovery. Our data support the findings by others showing that patients who received packed red cells during cardiac surgery have more complications during the postoperative course [24]. A multiple regression analysis identified the intra-operative transfusion of packed red cells as the most important independent variable significantly associated with worse postoperative performance, among classic risk factors age and female gender. However, the direct link between packed red cells transfusion and increased postoperative morbidity has yet to be established.

\section{Concluding remarks}

The findings of the present study are important for several reasons. This study shows for the first time that intra-operatively transfused units of packed red cells affect the perioperative release of inflammatory mediators in cardiac surgical patients. These transfusions affect the well-known systemic inflammatory response to cardiac surgery both by enhancing part of the response, and by direct transfusion of bioreactive substances into the circulation. Thus, our data implicate that the findings of previous studies on the release of inflammatory mediators in response to cardiac surgery and/or the cardiopulmonary bypass procedure that did not take the intra-operative administration of packed red cells transfusions into account need to be reconsidered.

In addition, we show that the intra-operative administration of allogeneic packed red cells in cardiac surgery coincided with increased postoperative 
morbidity. Since packed red cells contain considerable amounts of BPL, as was demonstrated in this study, other neutrophil granule proteins, such as elastase, cathepsin $\mathrm{G}$, and highly toxic defensins, may also be present in transfusion products. Future studies should reveal whether the administration of these bioreactive substances through blood transfusions directly affects postoperative morbidity.

\section{REFERENCES}

1. Fransen E, Maessen J, Dentener $M$. Senden N, Geskes $G$, Butrman W. Systemic intlammation present in patients undergoing $C A B G$ without extracorporeal circulation. Chest 1998;113:1290-5.

2. Fransen EJ, Maessen JG, Dentener MA, Gorgels APM, Buurman WA. Serum soluble TNF receptor as a risk lactor in patients with heart fallure. J Mol Cell Cardiol 1996;28:A69.

3. Wheatley T. Veitch PS. Effect of blood transfusion on postoperative immunocompetence. Br J Anaesth 1997;78:489-92.

4. Braga M, Vignali A, Radaelli G, Gianatti L, Di Carlo V. Association between perioperative blood transfusion and postoperative infection in patients having elective operations for gastrointestinal cancer. Eur J Surg 1992;158:531-6.

5. Heddle NM, Klama $L$, Singer $J$, et al. The role of the plasma from platelet concentrates in transfusion reactions. NEJM 1994;331:625-8.

6. Weerwind PW, Maessen JG, van Tits LJH, et al. Intluence of Durafto II heparin-treated extracorporeal circuits on the systemic inflammatory response in patients having coronary bypass. \& Thorac Cardiovasc Surg 1995:1 10:1633-41.

7. Dentener MA, Francot GJM. Smit FT, et al. Presence of bactericidal permeabilityincreasing protein in disease: detection by ELISA. I Infect Dis 1995; 171:739-43.

8. Dentener MA, Bazil V, Von Asmuth EJU, Ceska M. Buurman WA. Inwolvement of CD14 in lipopolysaccharide-induced tumor necrosis factor-a, $\mathrm{LL}-6$ and $\mathrm{IL}-8$ release by hurran monocytes and alveolar macrophages. J Immunol 1993; 150:2885-91.

9. Froon AHM. Dentener MA, Greve JWM, Ramsay G, Buurman WA. Lipopolysaccharide toxicity-regulating proteins in bacteremia. Infect Dis 1995;171:1250-7.

10. Garner JS, Jarvis WA, Enori TG. Horan TC, Hughes JM. CDC definitions for nasocomial intections, 1988. Am I Infect Control 1988; 16:128-40.

11. Dentener MA, Francot G.JM, Hiernstra PS, et al. Bactericidal/ permeability-increasing protein release in whole blood ex vivo: sirong induction by lipopolysaccharide and tumor necrosis factopalpha. J mfect Dis 1997;175:108-17.

12. Bouma MG, Maessen JG. Weerwind PW. et al. Release of LPS toxicity-modulating proteins in patients undergoing coronary bypass surgery using non-coated and heparincoated extra-comporeal circuits. Chest 1997:11 1:577-83.

13. Bordin JO, Heddle NM, Blajchman MA. Biologic effects of leukocytes present in transtused cellular blood products. Blood 1994:84:1703-21.

14. Steinberg JB, Kapelanski DP, OIson JD, Weiler JM. Cytokine and complement levels in patients undergoing cardiopulmonary bypass. J Thorac Cardiovasc Surg 1993;106:100816.

15. Holzheimer RG, Molloy AG, Görlach $H$, Wilkert S, Hehrlein F. IL-6 and TNF release in association with neutrophil activation after cardiopulmonary bypass surgery. Infection $1994: 22: 37-4: 2$

16. Stack G, Baril L, Napychank P, Snyder EL. Cytokine generation in stored, white cellreduced, and bacterially contaminated units of red cells. Transfusion 1995;35:199-203. 
17. Muylle L. Wouters E. Peetersmans ME Febrle reactions to platelet transfusion: the effect of increased interleukin-6 levels in concentrates prepared by the platelet-rich plasme method. Transfusion $1996 ; 36: 886=90$.

18. Muylle L, Peetermans ME. Effect of prestorage leukocyte removal on the cytokine levels in stored platelet concentrates. Vox Sang 1994:66:14-7.

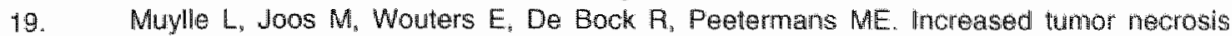
factor (TNF alpha), interleukin-1, and interleukin-6 (IL-6) levels in the plasma of stored platelet concentrates: relationship between TNF alphe and IL-6 levels and febrile transfusion reactions. Transfusion $1993 ; 33: 195-9$.

20. Gatter $U$, Kalechman $Y$, Sredni B. Blood transfusion enhances production of Thelper-2 cytokines and transforming growth factor beta in humans. Clin Sci Colch 1996;91:519-23.

21. Steel DM, Whitehead AS. The major acute phase reactants: Cureactive protein, sem amyloid $\mathrm{P}$ component and serum amyloid A protein. Immumol Today 1994;15:81-8.

22. Baumann $H$, Gauldie 1 . The acute phase response. Immunol Today 1994:15:74-80.

23. Goris RJA. MODSISIRS: Result of an overwheiming inflammatory response? World I Surg 1996;20:418-21.

24. van de Watering $L M G$, Hermans $J$, Houbiers JGA, et al. Beneficial effects of leukocyte depletion of transfused blood on pastoperative complications in patients undergoing cardiac surgery. A randomized clinical study. Circulation 1998:97:562-8. 



\section{CHAPTER}

\section{Demonstration of ischaemia-reperfusion injury separate from postoperative infarction in coronary artery bypass graft patients}




\section{ABSTRACT}

Purpose. In CABG patients there are two possible causes of myocardial injury, (1) global ischemic myocardial injury during aortic cross-clamping and subsequent reperfusion, and (2) postoperative myocardial infarction (MI). We studied the use of cardiac marker proteins to specifically and separately detect such injury.

Methods. Serum levels of enzymes (CK and CK-MB) and non-enzymatic proteins (FABP and myoglobin) were measured in 8 low-risk $C A B G$ patients with cardiopulmonary bypass (CPB), 8 low-risk $C A B G$ patients without $C P B$, and 39 high-risk $\mathrm{CABG}$ patients with $\mathrm{CPB}$, of whom 7 developed a postoperative M1.

Results. Already 0.5 hours after reperfusion significantly increased plasma levels of all markers were noted in patients having surgery with $\mathrm{CPB}$, but not in patients having surgery without $\mathrm{CPB}$. In patients who developed a postoperative MI, a second significant increase of each marker was found but that of FABP was recorded 4 hours earlier than that of $\mathrm{CK}, \mathrm{CK}-\mathrm{MB}$ or myoglobin.

Conclusions. (1) Perioperative myocardial injury can be diagnosed from the release of cardiac marker proteins into plasma already at 0.5 hours after start of reperfusion; (2) for carly assessment of postoperative MI, FABP is a more suitable plasma marker than are CK, CK-MB or myoglobin.

\section{INTRODUCTION}

In patients having cardiac surgery the assessment of possible myocardial tissue loss from the activity of cardiac enzymes in plasma is well accepted, both for (early) diagnosis of postoperative myocardial infarction and for estimation of the extent of infarction [1]. Large clinical trials commonly present peak levels of serum enzymes to express the extent of myocardial damage in evaluating surgical morbidity [2]. However, the surgical procedure limits the accuracy of enzymatic diagnosis of postoperative myocardial infarctions in these patients. Firstly, a distinction whether the enzymes originate from cardiac or non-cardiac muscle often can not be made. Secondly, the release features of the enzymes currently in use, such as CK, CK-MB and ASAT, allow definite diagnosis of myocardial infarction no earlier than about 12 hours after surgery [1]. Finally, cardiopulmonary bypass (CPB) and global ischaemia (aortic cross-clamping) may already elicit myocardial tissue loss, which may be difficult to differentiate 
from additional myocardial injury due to local infarction.

The aims of the present study were (1) to verify whether global ischaemia and reperfusion, as occurring in patients having coronary artery bypass grafting (CABG) with use of CPB and aortic cross-clamping, results in early myocardial injury detectable from increased plasma levels of cardiac proteins; and (2) whether, like in patients having an acute myocardial infarction (AMI), the use of more rapidly released and more cardiospecific markers allows an earlier diagnosis of possible postoperative myocardial infarction. For this, we retrospectively compared the release into plasma of enzymes and of the small cytosolic proteins heart-type fatty acid-binding protein (FABP, 15 kD) [3] and myoglobin $(17 \mathrm{kD})[4,5]$ in different groups of $\mathrm{CABG}$ patients. For the first aim, we studied the release of these enzymes and markers in low-risk patients having $\mathrm{CABG}$ either with or without $\mathrm{CPB}$ and aortic cross-clamping. For the second aim, we studied patients having CABG with $\mathrm{CPB}$ and aortic crossclamping who were at high risk for developing a postoperative myocardial infarction.

The results of the present study show that cardiac marker protein release can be used to determine myocardial tissue loss due to surgery, and to discriminate this from tissue loss caused by postoperative myocardial infarction. Furthermore, the use of FABP allows an earlier diagnosis of postoperative myocardial infarction than the use of $\mathrm{CK}, \mathrm{CK}-\mathrm{MB}$ and myoglobin.

\section{MATERIAL AND METHODS}

\section{Patients}

Sixteen adult low-risk patients undergoing elective $C A B G$ with or without the use of cardiopulmonary bypass (CPB group and NON-CPB group, respec. tively), were enrolled (eight in each group). NON-CPB patients all had single graft surgery. Furthermore, thirty nine adult high-risk patients undergoing elective CABG were enrolled. These patients were classified as having a highrisk for the development of postoperative MI based on the following criteria: LVEF $\leq 30 \%$ and $/$ or high dose inotropic support $(>7 \mu \mathrm{g} / \mathrm{kg} / \mathrm{min}$. dopamine or dobutamine) and/or preoperative use of an intra aortic balloon pump (IABP). Age boundaries were set between 30 and 80 years. Exclusion criteria were: (1) preoperative infarction or ongoing infarction, (2) treatment with fibrinolytics within 48 hours prior to surgery, (3) hepatic disease as indicated by ASAT and 
ALAT levels of more than 2 times the upper limit of normal, or by bilirubin levels of more than 1.5 times the upper limit of normal, and (4) severe coagulation abnormalities. Of these high-risk patients 32 did not develop a postoperative MI (NON-MI group), whereas 7 did (MI group). All subjects gave written informed consent for the study. The study was approved by the local ethical and research council.

\section{Intra-operative patient management}

Standard anesthetic (lorazepam, fentanyl citrate, sufentanil citrate, alfentanil hydrochloride, midazolam hydrochloride, pancuronium bromide) and monitoring techniques (electrocardiogram, central venous/pulmonary and arterial pressure monitoring, urinary output, rectal and skin temperature monitoring) were used in all patients. Before connection of the extracorporeal circuit for cardiopulmonary bypass, heparin was administered $(300 \mathrm{IU} / \mathrm{kg}$, Heparin Leo, Leo Pharmaceutical Products BV, Weesp, The Netherlands) in order to achieve an activated coagulation time $(A C T)>480 \mathrm{~s}$ (Hemochron 400, International Technidyne Corp., New Jersey, USA).

Specifications on the extracorporeal circulation circuit, cardiopulmonary bypass procedures and surgical procedures have been described previously [6]. In NON-CPB patients, after median sternotomy, coronary grafting was performed on a beating. normothermic heart. To dampen the movement of the beating heart and consequently isolate the region for anastomosis, a custom-made, $\mathrm{U}$ shaped stabilizer was used. Through its shaft, the stabilizer was attached to a slightly adjusted sternal retractor. Using vessel loops, a segmentary occlusion of the coronary artery to a length of $\pm 2.5 \mathrm{~cm}$ was used to control bleeding from the coronary artery during the anastomy procedure. Postoperative patient treatment in the coronary care unit was standardized and similar for all groups. None of the patients received thrombolytic agents.

\section{Blood sampling}

Blood samples in the CPB group were taken upon induction of anesthesia, at the start of aortic clamping, at the end of aortic clamping (start of reperfusion) and $0.5,1.5,4,8,12,18$ and 24 hours thereafter. In the NON-CPB group, samples were taken upon induction of anesthesia and $0.5,1.5,4,8,12$ and 18 hours after unclamping the internal mammary artery (in one patient after unclamping the venous graft) (start of reperfusion). In the NON-MI and MI group, blood 
samples were taken at the same timepoints as in the CPB group. All samples were collected in Corvac integrated serum separator tubes $(10 \mathrm{ml}$, Corvac, Sherwood Medical, St. Louis, MO, USA). Immediately after sampling, blood was cooled, routinely centrifugated, and serum samples were stored at $-80^{\circ} \mathrm{C}$ until assay.

Ml diagnosis

A cardiologist, who was blinded for any other patient data, established diagnosis of postoperative myocardial infarction. He compared a preoperative with three postoperative electrocardiograms, obtained up to 24 hours after surgery. The electrocardiograms were screened for new persistent $Q$ waves and ST segment deviations ( $\geq 1 \mathrm{~mm}$ ST segment elevation in $\geq 2 \mathrm{limb}$ leads and/or $\geq 2$ $\mathrm{mm}$ ST segment elevation in $\geq 2$ precordial leads).

\section{Analytical techniques}

The activities of $\mathrm{CK}$ and $\mathrm{CK}-\mathrm{MB}$ were measured spectrophotometrically at $25^{\circ}$ $\mathrm{C}$ in a centrifugal analyzer (Cobas Bio Systems, Hoffmann La Roche, Basel, Switzerland) with commercially available test kits. The CK-MB assay is based on immunoinhibition of the predominant $\mathrm{M}$ unit in creatine kinase (Boehringer Mannheim, Germany). Serum FABP concentration was measured with a sensitive non-competitive enzyme-linked immunosorbent assay of the antigen capture type (sandwich ELISA) [7]. Serum myoglobin was measured with a turbidimetric immunoassay (Unimate $3 \mathrm{MYO}$, Roche Diagnostics Systems, Basel, Switzerland) on a Cobas Mira Plus analyzer (Roche).

\section{Data analysis}

All data are presented as mean \pm standard error of the mean (SEM). Students' ltest for independent samples was used for comparisons between two variables at the same time point. A Wilcoxon Matched-Pairs Signed-Ranks Test was used for comparisons of values from one variable between two time points. A $\chi^{2}$ - test was used to test non-numeric variables. The level of significance was set $a t p<$ 0.05 . 


\section{RESULTS}

Clinical characteristics

The perioperative characteristics of all patients are shown in Table 1 .

Table 1. Pert pperative characteristics of patient groups

\begin{tabular}{|c|c|c|c|c|}
\hline \multirow[b]{2}{*}{ Variable } & \multicolumn{2}{|c|}{ Low-Risk Patients } & \multicolumn{2}{|c|}{ Hich-Risk Patients } \\
\hline & $\begin{array}{c}\text { CPB } \\
(n=8)\end{array}$ & $\begin{array}{c}\text { NON-CPE } \\
(n=8)\end{array}$ & $\begin{array}{l}\text { NON-MI } \\
(n=32)\end{array}$ & $\begin{array}{c}M \\
(n=7)\end{array}$ \\
\hline Age (yr.) & $64 \pm 4$ & $51 \pm 4$ & $63 \pm 2$ & $63 \pm 2$ \\
\hline Male / Female & $4 / 4$ & $4 / 4$ & $26 / 6$ & $6 / 1$ \\
\hline CPB time (min.') & $115 \pm 15$ & 0 & $99 \pm 6$ & $104 \pm 14$ \\
\hline ACC time (min.) & $67 \pm 9$ & 0 & $63 \pm 4$ & $70 \pm 12$ \\
\hline Number of grafts & $3.2 \pm 0.6$ & 1 & $4.5 \pm 0.3$ & $5.0 \pm 0.7$ \\
\hline \multicolumn{5}{|l|}{ Preoperative } \\
\hline Urea (mmol/L) & $7.1 \pm 0.9$ & $4.5 \pm 0.2^{\circ}$ & $7.0 \pm 0.4$ & $5.7 \pm 0.8$ \\
\hline Creatinine (mmol/h) & $92 \pm 4$ & $85 \pm 2$ & $102 \pm 4$ & $97 \pm 6$ \\
\hline \multicolumn{5}{|l|}{ Postoperative } \\
\hline Urea (immolfíl) & $5.6 \pm 0.7$ & $3.7 \pm 0.6$ & $7.5 \pm 0.6$ & $7.1 \pm 1.1$ \\
\hline Creatinine (kmol/L) & $100 \pm 9$ & $74 \pm 4$ & $121 \pm 10$ & $130 \pm 14$ \\
\hline \multicolumn{5}{|l|}{ Preoperative } \\
\hline$C K(U / L)$ & $16 \pm 3$ & $15.8 \pm 3$ & $35.9 \pm 10$ & $55.4 \pm 20$ \\
\hline$C K-M B(\mu g / L)$ & $2.1 \pm 0.5$ & $2.4 \pm 0.3$ & $39 \pm 1$ & $6.1 \pm 3$ \\
\hline FABP $(\mu g / L)$ & $2.4 \pm 1.2$ & $2.9 \pm 1$ & $2.2 \pm 1$ & $2.6 \pm 2$ \\
\hline Myoglobin $\left(\mu g^{\prime} L\right)$ & $34.8 \pm 4$ & $28.1 \pm 2$ & $40.5 \pm 5$ & $34.6 \pm 6$ \\
\hline
\end{tabular}

Values are meen * SEM. ACC, aortic crossclamp. CK, creatine kinase. CK.MB, creatine kinase isoenzyme MB. CPB, cardiopulmonary bypass. FABP, fatty acid-binding protein. MI, myocardial infarction. P<0.05, CPE Ws. NOM-CPB.

Patient characteristics were similar in each group, except for age, number of grafts, preoperative urea and postoperative creatinine, which each were lower in NON-CPB patients. The lower age and lower number of grafts in these patients are explained by the fact they had single vessel disease, which is usually seen at younger age. The lower mean preoperative urea and postoperative creatinine concentrations in NON-CPB patients, compared to CPB patients, also relate to their lower age; however, both mean values are within normal range. Therefore, there is no indication for renal insufficiency in either patient group. One patient 
in the NON-CPB group developed a postoperative myocardial infarction. Data of this patient are shown separately.
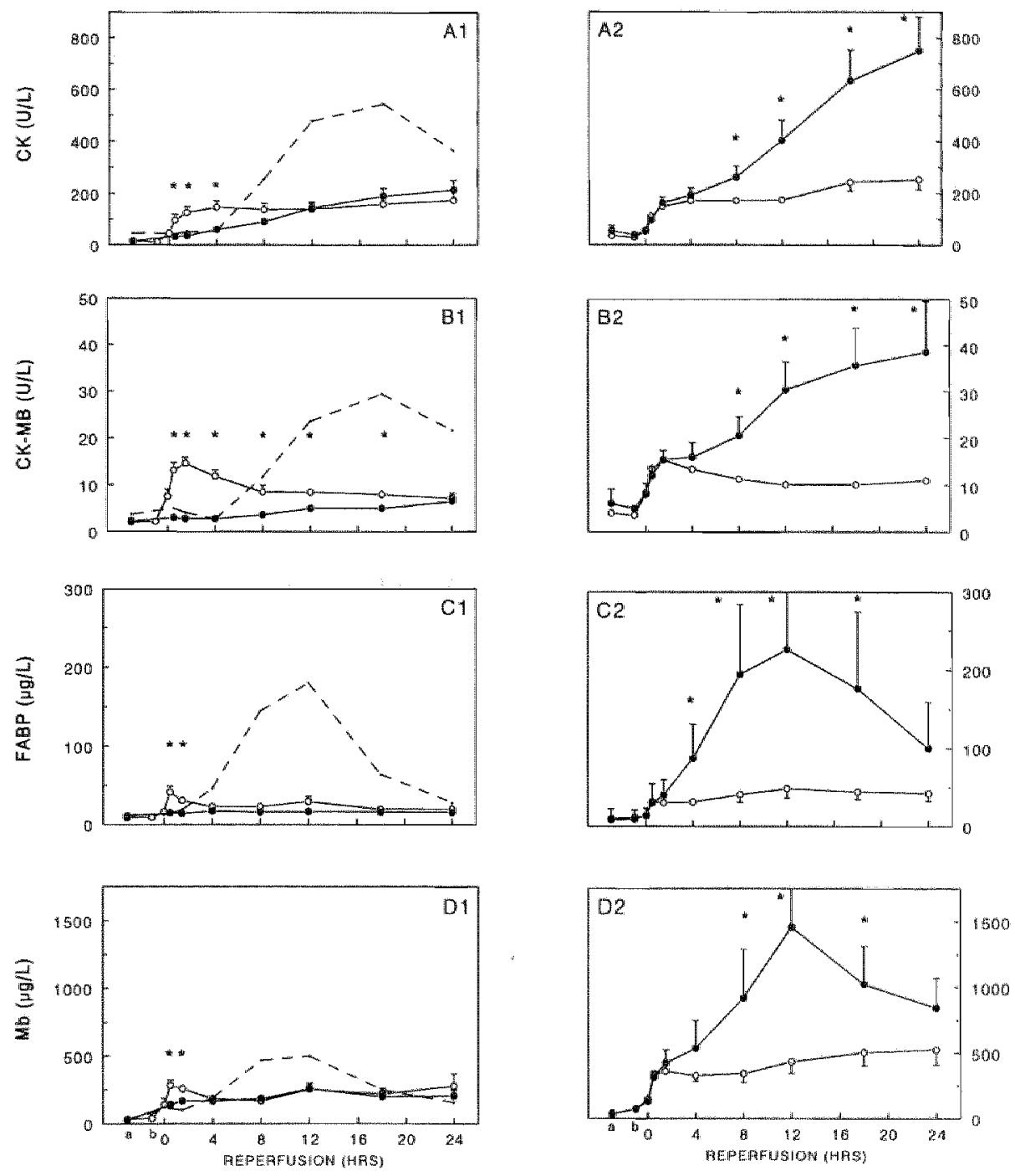

Figure 1. Mean serum concentrations of enzymes and cardiac marker proteins preoperatively (a), at the start of aortic clamping (b) and at $0.5,1.5,4,8,12,18$ and 24 hours after start of reperfusion in low risk patients who had surgery with $C P B\left(O_{1} n=8\right)$, or without $C P B(\bullet, n=7)$ (left panels) and in high risk patients who did $(\bullet, n=7)$ or did not $(0, n=32)$ have a postoperative MI (right panels). In the left panels data from the patient in the NON-CPB group who had a postoperative MI are shown as a dashed line. " $<<0.05$, ws. 0 . Mb, myoglobin. 
Serum enzymes and proteins in low risk patients (figure 1, left panels)

In the CPB group, senum levels of all markers tested increased rapidly during the early postoperative phase while there was virtually no such increase in the NON-CPB group (Figure 1, panels A1 to D1). The presence of early myocardial injury in the CPB group, as opposed to the NON-CPB group, is apparent from a very rapid and brief release of $F A B P$ and myoglobin, both proteins showing maximal concentrations already at 0.5 hours after reperfusion ( 42 and $287 \mu \mathrm{g} / \mathrm{L}$, respectively). The other two markers, $C K$ and $C K-M B$, were also significantly increased within this short time interval, and $\mathrm{CK}-\mathrm{MB}$ reached peak concentrations of 127 and $15 \mathrm{U} / \mathrm{L}$, respectively, already at 1.5 hours after reperfusion. For CK, and to some extent also for myoglobin, the early postoperative burst of protein release is obscured by subsequent release of these markers from skeletal muscle, as appears from the steady and relatively large postoperative increase of the markers in plasma seen in the NON-CPB group.

In the patient from the NON-CPB group who developed a postoperative MI, the curves of all markers resembled those found for the first 4 hours in the other NON-CPB patients, whereas thereafter the curves were similar to those found in MI patients with earlier peak concentrations for FABP and myoglobin compared to the enzymes studied (see below).

Serum enzymes and proteins in high risk patients (figure 1, right panels)

CK activities in the NON-MI and MI groups each increased above preoperative levels (Table 1) and were similar until 4 hours of reperfusion. From this timepoint on, postoperative $C K$ activity in the NON $-M I$ group remained elevated to a similar extent, whereas the CK activity in the MI group persistently increased until 24 hours of reperfusion, at this time being 3 fold higher than in the controls (Figure 1, panel A2). Thus, CK levels in the MI group were significantly higher than in the NON-MI group from 8 to at least 24 hours of reperfusion. Similarly, CK-MB activities in the NON-MI and the MI group each increased until 1.5 hours of reperfusion, and then further increased only in the MI group (Figure 1, panel B2). From 8 to 24 hours of reperfusion CK-MB levels were significantly higher in the MI group $(p<0.05)$. FABP and myoglobin concentrations also increased until 0.5 hours of reperfusion (Figure 1, panels C2 and D2) in both NON-MI and MI patients. In MI patients, FABP and myoglobin concentrations continued to increase, reaching peak levels at 12 hours of reperfusion which were 4 (FABP) and 2.5 times (myoglobin) higher compared to NON-MI 
patients. A significant difference in FABP plasma concentrations between NON-MI and MI patients was reached at 4 hours of reperfusion, whereas for the other three markers a statistically significant difference was reached not until 8 hours of reperfusion.

For each of the four markers and at all perioperative time points studied, the mean serum activities and concentrations found in CPB patients were not significantly different from those found in NON-MI patients. This notion is exemplified for CK and FABP in figure 2.
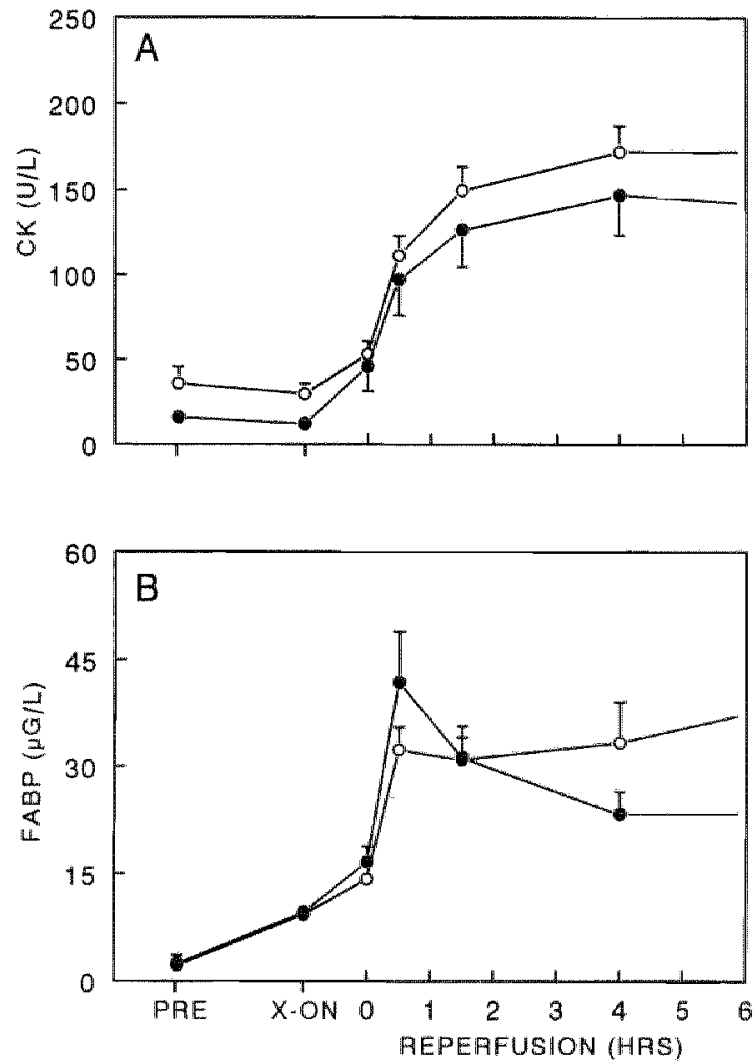

Flgure 2. Mean serum activities of $\mathrm{CK}$ and serum concentrations of FABP preoperatively (PRE), at the stant of aortic clamping (X-ON) and at $0,0.5,1.5$ and 4 hours after start of reperfusion in patients from the CPB group $(\bullet, n=8)$ and from the NON-MI group $\left(O_{n} n=32\right)$. 


\section{DISCUSSION}

Myocardial tissue injury is inevitable in cardiac surgery. It is unclear to what extent this leads to a substantial increase in plasma concentrations of cardiac marker proteins and cardiac specific enzymes during the early postoperative period in these patients. Furthermore, it is unknown whether and/or what extent the (early) relcase of these markers and enzymes obscures the diagnosis of postoperative myocardial infarction.

At present, 'new' cardiac marker proteins (FABP, myoglobin, troponin T) are being applied successfully for early diagnosis of acute myocardial infarction in patients suspected of acute myocardial infarction (AMI) [8]. FABP is a small (15 kDa) cytoplasmic protein involved in intracellular fatty acid transport in myocytes. It is present in a wide variety of tissues, but the highest concentration is found in cardiac muscle tissue where it comprises 3 to $6 \%$ of cytosolic protein [9-11]. In rats, FABP was found to be released after ischaemia and reperfusion soon after start of reperfusion [12]. Recently, FABP was proposed as an early marker for AMI [13-17]. Myoglobin, another small (17 kDa) cardiac cytoplasmic protein, was put forward for the same purpose $[4,5,18,19]$, and is also rapidly released after ischaemia and reperfusion [20]. Because of its higher cardiospecificity, FABP is preferred over myoglobin for detection of postoperative MI [2], 22].

In the present study, NON-CPB patients showed no immediate postoperative rise of enzyme activities and cardiac marker protein concentrations in plasma, but only a relatively slow increase cluring 24 hours of reperfusion. Maximal increases were $13.5,9.3,6.4$ and 2.7 times the preoperative concentration for CK, myoglobin, $\mathrm{CK}-\mathrm{MB}$ and $\mathrm{FABP}$, respectively, reflecting differences in tissue protein contents, their elimination rates from plasma and involvement of skeletal muscle injury [20-22]. In CPB patients, all markers showed a much faster increase, especially during the first 1.5 hours after reperfusion. In these patients, already at 0.5 hours after aortic unclamping levels of all markers studied were significantly higher than in NON-CPB patients. These data indicate that the use of cardiopulmonary bypass in combination with aortic clamping during $\mathrm{CABG}$, elicits ischaemia-reperfusion injury which can be estimated soon after aortic unclamping and equally well using any of the four plasma markers studied.

This early increase was also shown in both the NON-MI and MI patients but, in addition. Ml patients showed a second increase in plasma enzyme activities and cardiac marker protein concentrations, indicating additional myocardial 
injury. Although this second increase was observed for all markers, a significant difference between MI and NON-MI patients was first seen already at 4 hours after reperfusion in case of FABP, but for the other three markers became significant not until 8 hours after reperfusion. Thus, all markers allow the differentiation between MI and NON-MI patients, but FABP measurements enable postoperative MI to be diagnosed earlier than do the other markers.

Mechanisms of enzyme and protein release and elimination after myocardial injury

Enzyme levels as well as marker protein concentrations in serum, already showed some increase during aortic clamping (global ischaemia) in all patients having surgery with use of CPB. Since during aortic clamping the coronary circulation is isolated from the rest of the body, this indicates some transport of enzymes and myocardial marker proteins via the lymphatic system. During the first half-hour of subsequent reperfusion, a simultaneous increase in serum levels of all markers was observed. Apparently, molecular size did not influence the appearance of markers in plasma suggesting significantly increased lymph flow early after reperfusion, as also found in isolated rat hearts $[23,24]$.

In contrast, non-simultaneous release of marker proteins was observed in patients having postoperative MI, indicating faster intravasation of the small proteins FABP and myoglobin than of the larger enzymes $\mathrm{CK}$ and $\mathrm{CK}-\mathrm{MB}$, similar to the route of protein transport to the circulation during AMI [13]. Based on these data, the protein permeability of the endothelial barrier seems to be normalized early after surgery.

The kidney plays a dominant role in the rapid disappearance of both myoglobin and FABP from plasma $[5,25,26]$. Renal handling of FABP and myoglobin is affected by several factors, such as renal blood flow, perfusion pressure, glomerular filtration, and tubular reabsorption. Therefore, to exclude false-positive conclusions regarding $M I$ because of renal failure, we used preoperative and postoperative serum levels of urea and creatinine as indices of renal function. As all levels were in normal range, there were no signs of renal malfunction in the patients studied. However, FABP and myoglobin measurements as a diagnostic marker for postoperative MI in cardiac surgical patients with severe renal failure (e.g. acute tubullar necrosis) could lead to false conclusions.

For the early diagnosis of postoperative myocardial infarction with FABP, a rapid assay system is a prerequisite to fully benefit from its rapid release and 
clearance features. Now that analytical techniques for bed-side determinations of FABP are available [27], FABP measurements may become an important tool for diagnosing perioperative myocardial damage. In cardiac surgical clinical practice this means that one does not have to wait until 12 hours after surgery before MI can be diagnosed [1]. Consequently, in view of present fasttrack programs, postoperative treatment of cardiac surgical patients could be improved, for instance by earlier weaning from intra-aortic balloon pump, earlier transportation to the ward and eventually earlier discharge. Future studies should focus on determining threshold levels for FABP, so that with bedside analysis of this cardiac marker protein an appropriate diagnosis of postoperative MI can be made.

\section{REFERENCES}

1. Lee TH, Goldman L. Serum enzyme assays in the diagnosis of acute myocardial infarction. Recommendations based on quantitative analysis. Ann Intern Med 1986;105:221-33.

2. Multicenter Study of Perioperative Ischemia (McSPl) Research Group. Effects of acadesine on the incidence of myocardial infarction and adverse cardiac outcomes after coronary artery bypass graft surgery. Anesthesiology 1995;83:658-73.

3. Van Nieuwenhoven FA, Musters R.JP, Post JA, Verkleij AJ, Van der Vusse GJ, Glatz JFC. Release of proteins from isolated neonatal rat cardiomyocytes subjected to simulated ischaemia or metabolic inhibition is dependent of molecular mass. 1 Mol Cell Cardiol $1996 ; 28: 1429-344$.

4. Isakov $A$, Shapira I, Burke $M$, Almog C. Serum myoghlobin levels in patients with ischemic myocardial insult. Arch Intern Med 198:; 148:1762-5.

5. Kinoshita $K$, Tsuruhara $Y$, Tokunaga $K$. Delayed time to peak serum myoglobin level as an indicator of cardiac dysfunction following open heart surgery. Chest 1991;99:1398-402.

6. Weerwind PW, Maessen JG, van Tits LJH, et al. Influence of Duraflo II heparin-treated extracorporeal circuits on the systemic inflammatory response in patients having coronary bypass. I Thorac Candiovasc Surg 1995; 110:1633-41.

7. Wodzig KWH, Polsers MMAL, van der Vusse GJ, Roos W, Glatz JFC. One-step enzymelinked immunosorbent assay (ELISA) for plasma fatty acid-binding protein. Am Cin Biochern 1997;34:263-8.

8. Adams JE, Abendschein DR, Jafie AS. Blochemical markers of myocardial injury. Is MB creatine kinase the choice for the 1990s? Circulation 1993;88:750-63.

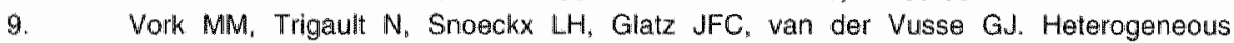
distribution of fatty acid-binding protein in the hearts of Wistar Kyoto and spontaneously hypertensive rats. J Mol Cell Cardiol 1992,24:317-21.

10. Glat2 JFC, van der Vusse GJ. Cellular fatty acid-binding proteins: their function and physiological significance. Prog Lipid Res 1996;35:243-82.

11. Kim HK. Storch J. Mechanism of free fatty acid transfer from rat heart fatty acid-binding protein to phospholipid membranes. Evidence for a collisional process. $J$ Biol Chem 1992; 267:2005i-6.

12. Das DK, Barua PK, Jones RM. Release of fatty acid-binding protein from ischemicreperfused rat heart and its prevertion by mepacrine. Biochim Biophys Acta 1991:1073: 394-401.

13. Glatz JFC, Kleine AH, van Nieuwenhoven FA, Hermens WT, van Dieijen Visser MP, van 
der Vusse GJ. Faty-acid-binding protein as a plasma marker for the estimation of myocardial infarct size in humans, Br Heart $J 1994 ; 71: 135-40$.

14. Glatz JFC, van Bilsen M, Paulussen PJA, Veerkamp JH, van der Vusse GJ. Fenemen RS. Release of latty acid-binding protein from isolated rat heart sultjected to ischaemia and reperfusion ar to the calcium paradox. Biochim Biophys Acta 1988;961:148-52.

15. Kleine $\mathrm{AH}$, Glatz JFC, van Nieuwenhowen FA, van dell Vusse GJ. Release of heart fatty acid-binding protein into plasma after acute myocardial infarction in man. Mol Cell Biochem 1992;116:155-62.

16. Tanaka $T$, Hirota $\%$. Sohmiya K, Nishimura $S$, Kawamura K. Serum and urinary human heart fatty acid-binding protein in acute myocardial infarction. Clin Biochem 1991;24:195201.

17. Knowton AA, Apstein CS, Saouf $R$, Brecher $P$. Leakage of heart latty acid-binding protein with ischemia and reperfusion in the rat. J Mol Cell Cardiol 1989:21:577-83.

18. Séguin $J_{1}$ Saussine $M$. Ferrière $M$, et al. Comparison of myoglobin and creatine kinase MB levels in the evaluation of myocardial injury after cardiac operations. $J$ Thorac Cardiovasc Surg $1988 ; 95: 294-7$.

19. Mair P, Mair J, Seibt I, Balogh D. Puschendort B. Early and rapid diagnosis of perioperative myocardial infarction in aontocoronary bypass surgery by immunoturbidimetric myoglobin measurements. Chest 1993;103:1508-11.

20. Ellis AK, Little T. Masud ARZ, Klocke FJ. Patterns of myoglobin release alter repertusion of injured myocardium. Circulation $1985 ; 72: 639-47$.

21. Van Nieuwenhoven FA, Kleine $\mathrm{AH}$, Wodzig KWH, et al. Discrimination between myocardial and skeletal muscle injury by assessment of the plasma ratio of myoglobin over fatty acid-binding protein. Circulation 1995;92:2848-54.

22. Yoshimoto $K$, Tanaka $T$, Somiya $K$, et al. Human heart-type cytoplasmic fatty acid-binding protein as an indicator of acute myocardial infarction. Heart and Vessels 1995; 10:304-9.

23. Vork MM, Glatz JFC, Surtel DA, Knubben HJ, van der Vusse GJ. A sandwich enzyme linked immuno-sorbent assay for the determination of rat heart type fatty acid-binding protein using the streptavidin-biotin system. Application to tissue and effluent samples from normoxic rat heart perfusion. Biochim Biophys Acta 1991"1075:199-205.

24. Vork MM, Glatz JFC, Surtel DA, van der Vusse GJ. Rellease of fatty acidubinding protein and lactate dehydogenase from isolated rat heart during normoxia, low-flow ischaemia, and repertusion. Can J Physiol Pharmacol 1993;71:952-8.

25. Sohmiya $K$. Tanaka T, Tsuji $\mathrm{A}$, et al. Plasma and urinary heart-type cytoplasmic fatty acidbinding protein in coronary occlusion and reperfusion induced myocardial injury model. $J$ Mol Cell Cardiol 1993:25:1413-26.

26. Górski J, Hermens WT, Borawski Jl Mysliwiec M, Glatz JFC. Increased fatty acid-binding protein concentration in plasma of patienis with chronic renal failure. Clin Chem 1997;43: $193-5$.

27. Siegmann-Thioss $G$. Renneberg F. Glatz JFC. Spener F. Enzyme immunosensar for diagnosis of myocardial infarction. Sensors and Actualors 1996:B 30:71-6. 

CHAPTER

Perioperative myocardial tissue injury and the release of inflammatory mediators in coronary artery bypass graft patients

Submitted for publication 


\section{ABSTRACT}

Purpose. This study was conducted to evaluate to what extent the ischemiareperfusion injury resulting from the cardiopulmonary bypass $(\mathrm{CPB})$ and aortic cross-clamping procedures during coronary artery bypass grafting (CABG) contributes to the systemic inflammatory response generally found in these patients.

Methods. Serum levels of enzymes (CK and CK-MB) and non-enzymatic proteins (FABP and myoglobin) as markers of myocardial tissue injury, bactericidal permeability increasing protein (BPI) as an indicator of neutrophil activation, interleukin-6 (IL-6) as inducer of the acute phase response and lipopolysaccharide binding protein (LBP) as parameter of the acute phase response were measured in 15 low-risk CABG patients with cardiopulmonary bypass (CPB), and 17 low-risk $C A B G$ patients without $C P B$.

Results. Already 0.5 hours after reperfusion significantly increased plasma levels of all markers of myocardial tissue injury were noted in patients having surgery with $\mathrm{CPB}$, but not in nonCPB patients. BPI release from neutrophil granules markedly increased at 0.5 and 4 hours after reperfusion in $\mathrm{CPB}$ patients, but not in nonCPB patients. BPI and IL-6 levels on the first postoperative day were significantly higher in nonCPB patients $(p<0.05)$. No correlations were found for any marker of perioperative tissue damage with early neutrophil activation, or acute phase reactants.

Conclusions. Perioperative myocardial injury resulting from $\mathrm{CPB}$ and aortic cross-clamping in low-risk CABG patients, does not contribute to the release of inflammatory mediators in these patients.

\section{INTRODUCTION}

In patients undergoing coronary artery bypass grafting (CABG), the use of cardiopulmonary bypass (CPB) in combination with aortic clamping during coronary artery bypass grafting (CABG) elicits ischemic myocardial injury [1]. Furthermore, these patients experience systemic inflammation leading to an acute phase response with sepsis-like symptoms during postoperative recovery $[2,3 \%$. Experimental models of ischemic myocardial injury and observations in patients with myocardial infarction indicate that ischemic myocardial damage is associated with inflammation [4-7]. Therefore, in the present study, we hypothesized that ischemic myocardial injury as occurring in CABG patients opera- 
ted on with CPB and aottic cross-clamping, may be associated with the release of inflammatory mediators in these patients.

Measuring markers of myocardial tissue injury and inflammatory mediators in patients undergoing $\mathrm{CABG}$ with or without $\mathrm{CPB}$ might answer the question as to what extent the myocardial tissue injury resulting from the $C P B$ and aortic cross-clamping procedures contributes to the systemic inflammatory response in these patients.

Therefore, in the present study, we compared the release into plasma of enzymes, cardiac marker proteins, and mediators of inflammation in patients undergoing $\mathrm{C} A \mathrm{BG}$ either without $\mathrm{CPB}$, or with normothermic $\mathrm{CPB}$ (including aortic cross-clamping). In these patients we measured creatine kinase (CK), creatine kinase-MB (CK-MB), fatty acid-binding protein (FABP) and myoglobin as markers of myocardial tissue loss. Ir addition, we measured bactericidal permeability increasing protein (BPI) as an indicator of polymorphonuclear neutrophil (PMN) activation, interleukin(IL)-6 as inducer of the acute phase response and lipopolysaccharide binding protein (LBP) as parameter of the acute phase response. Using these data we were able to examine the relation between global ischemia and reperfusion and the systemic inflammatory response.

\section{MATERIALS AND METHODS}

\section{Patients}

A total of 32 adult low-risk patients undergoing elective $\mathrm{CABG}$ either with or without the use of cardiopulmonary bypass (CPB group $(n=15)$ and nonCPB group $(n=17)$, respectively), were enrolled. In the nonCPB group, no more than 2 distal anastomoses were made. None of the patients received allogeneic packed red cells intra-operatively. The study was performed according to the rules of the local ethical and research council.

\section{Intra-operative patient management}

Standard anesthetic (lorazepam, fentanyl cilrate, sufentanil citrate, alfentanil hydrochloride, midazolam hydrochloride, pancuronium bromide) and monitoring techniques (electrocarcliogram, central venous/pulmonary and arterial pressure monitoring, urinary output, rectal and skin temperature monitoring) were used in all patients. Before connection of the extracorporeal circuit for cardiopulmonary bypass, heparin was administered (300 IU $/ \mathrm{kg}$, Heparin Leo, 
Leo Pharmaceutical Products BV, Weesp. The Netherlands) in order to achieve an activated coagulation time $(A C T)>480 \$$ (Hemochron 400 , International Technidyne Corp., New Jersey, USA).

Specifications on the extracorporeal circulation circuit, cardiopulmonary bypass procedures and surgical procedures have been described previously [8]. In $\mathrm{CPB}$ patients, target flow rates of 2.4 to $2.6 \mathrm{~L} / \mathrm{min}$ per square meter were maintained. In case of low mean arterial pressure, phenylepinephrine or aramine was administered. During the whole CPB procedure (including the period of aortic cross-clamping), the arterial blood temperature was kept at approximately $36^{\circ} \mathrm{C}$, and attention was given to keep the right heart empty. In nonCPB patients, after median sternotomy, coronary grafting was performed on a beating, normothermic heart. To dampen the movement of the beating heart and consequently isolate the region for anastomosis, a custom-made, U-shaped stabilizer was used. Through its shaft, the stabilizer was attached to a slightly adjusted stemal retractor. Using vessel loops, a segmentary occlusion of the coronary artery to a length of $\pm 2.5 \mathrm{~cm}$ was used to control bleeding from the coronary artery during the anastomy procedure. Postoperative patient treatment in the coronary care unit was standardized and similar for all groups. None of the patients received thrombolytic agents.

\section{Blood sampling}

Blood samples in the CPB group were taken upon induction of anesthesia, and at $0.5,1.5,4,8,12,18$ hours after the start of reperfusion. In the nonCPB group, samples were taken upon induction of anesthesia and $0.5,1.5,4,8,12$ and 18 hours after unclamping the internal mammary artery or the venous graft (start of reperfusion). Samples at 1.5 and 12 hours after the start of reperfusion were collected only for enzyme measurements. For enzyme and cardiac marker protein measurements, samples were collected in Corvac integrated serum separator tubes $(10 \mathrm{ml}$, Corvac, Sherwood Medical, St. Louis, MO, USA). For inflammatory mediator measurements, samples were collected in evacuated blood collection tubes (10 ML, Monoject, Sherwood Medical, Ballymoney, N. Ireland) containing ethylenediamine-tetraacetic acid. Immediately after sampling, blood was cooled, routinely centrifugated, and serum samples were stored at $-80^{\circ} \mathrm{C}$ until assay. 
The activities of $\mathrm{CK}$ and $\mathrm{CK}-\mathrm{MB}$ were measured spectrophotometrically at $25^{\circ}$ $C$ in a centrifugal analyzer (Cobas Bio Systems, Hoffmann La Roche, Basel, Switzerland) with commercially available test kits. The CK-MB assay is based on immunoinhibition of the predominant $\mathrm{M}$ unit in creatine kinase (Boehringer Mannheim, Germany). Serum FABP concentration was measured with a sensitive non-competitive enzyme-linked immunosorbent assay of the antigen capture type (sandwich ELISA) [9]. Serum myoglobin was measured with a turbidimetric immunoassay (Unimate 3 MYO, Roche Diagnostics Systems, Basel, Switzerland) on a Cobas Mira Plus analyzer (Roche).

Plasma levels of BPI, IL-6 and LBP were measured using sandwich enzymelinked immunosorbent assays (ELISAs), which have been described elsewhere. In short, 96-well plates (Immuno-Maxisorp; Nunc, Roskilde, Denmark) were coated overnight at $4^{\circ} \mathrm{C}$ with the appropriate antibodies and free sites were blocked with $1 \%$ bovine serum albumin in PBS. Samples and standard dilution series were added for 2 hours. For measurement of BPI [10], human BPIspecific monoclonal antibody $4 \mathbb{E} 3$ was used for coating. Human recombinant BPI (kindly provided by M. Marra, Incyte, Pallo Alto, CA) was used for standard titration curves. Washing and dilution buffers contained $80 \mathrm{mM}$ magnesium chloride to prevent disturbance by lipopolysaccharide. Biotinylated polyclonal rabbit anti-human BPI IgG was used as detection antibody. The detection limit for the BPI-assay was $200 \mathrm{pg} / \mathrm{ml}$. For the [L-6 ELISA [11], plates were coated with the murine monoclonal antibody $5 \mathrm{E} 1$. Human rlL-6 (a kind gift from Prof. W. Sebald, Psychiologisch-Chemisches Institut der Universität Würburg, Germany) was used for standard titration curves. Biotinylated polyclonal rabbit anti-human IL-6 antiserum was used for detection. IL-6 could be detected with a lower limit of $10 \mathrm{pg} / \mathrm{ml}$. Polyclonal anti-human LBP $\ \mathrm{gG}$ was used as coating for the LBP ELISA [12]. Human recombinant LBP (provided by M. Marra, Incyte) was used for standard titration curves. Washing and dilution buffers contained $40 \mathrm{mM}$ magnesium chloride to prevent disturbance by lipopolysaccharides. Detection occurred with a biotinylated polyclonal rabbit anti-human LBP IgG. The detection limit was $500 \mathrm{pg} / \mathrm{ml}$. Biotinylated antibodies were detected with peroxidase-conjugated streptavidin (Zymed, San Francisco, CA). Finally, 3,3'5,5'-tetramethylbenzidine (Kirkegaard \& Perry Laboratories, Gaithersburg, MD) was used as a substrate. Photospectrometry $(450 \mathrm{~nm})$ was performed using a micro-ELISA autoreader. All plasma samples were analyzed in the same run. 
Data analysis

All data are presented as mean \pm standard error of the mean (SEM). A Mann Whitney U-test was used for comparisons between two variables at the same timepoint. A Wilcoxon Matched-Pairs Signed-Ranks Test was used for comparisons of values from one variable between two time points. A $\chi^{2}$-test was used to test non-numeric variables. The level of significance was set at $p$-values lower than 0.05 .

\section{RESULTS}

Clinical characteristics

The perioperative characteristics of both patient groups are shown in Table 1. Patient characteristics were similar in both patient groups, except for the number of grafts anastomized.

Table 1. Perioperative characteristics of the lwo patient groups

\begin{tabular}{lccc}
\hline & $\begin{array}{c}\text { CPB } \\
(n=15)\end{array}$ & $\begin{array}{c}\text { nonCPB } \\
(n=17)\end{array}$ & p Value \\
\hline Age (yrs) & $58 \pm 2$ & $55 \pm 3$ & $n s$ \\
BSA $\left(\mathrm{m}^{2}\right)$ & $1.91 \pm 0.1$ & $1.88 \pm 0.04$ & $n s$ \\
Sex (M/F) & $6 / 9$ & $11 / 6$ & $n s$ \\
CPB duration (min) & $32 \pm 2$ & 0 & \\
ACC duration (min) & $18 \pm 2$ & 0 & $<0.05$ \\
Number of grafts & $1.7 \pm 0.1$ & 1.1 & \\
\hline
\end{tabular}

Data are presented as mean $\pm S E M$. ACC, aortic cross-clamping. BSA, body surface area. CPB, cardiopulmonary bypass, ns, non*significant.

Serum enzymes and cardiac marker proteins

In the CPB group, serum levels of all markers tested increased rapidly during the early postoperative phase, while there was virtually no such increase in the nonCPB group (Figure 1, panels A to D). The presence of early myocardial injury in the $\mathrm{CPB}$ group, as opposed to the nonCPB group, is demonstrated by a very rapid and brief release of FABP and CK-MB. Maximal FABP concentrations were shown already at 0.5 hours after reperfusion $(12.4 \mu \mathrm{g} / \mathrm{L})$, 
whereas $\mathrm{CK}-\mathrm{MB}$ reached highest mean plasma levels at 1.5 hours after reperfusion $(7.7 \mathrm{U} / \mathrm{L})$. The other two markers, $\mathrm{CK}$ and myoglobin, were significantly increased between 0.5 and 4 hours after the start of reperfusion, and at 0.5 hours after the start of reperfusion, respectively. For the latter two markers, the perioperative release from the myocardium is probably obscured by subsequent release of these markers from skeletal muscle. This is exemplified by the steady and relatively large increase of these markers in nonCPB patients.
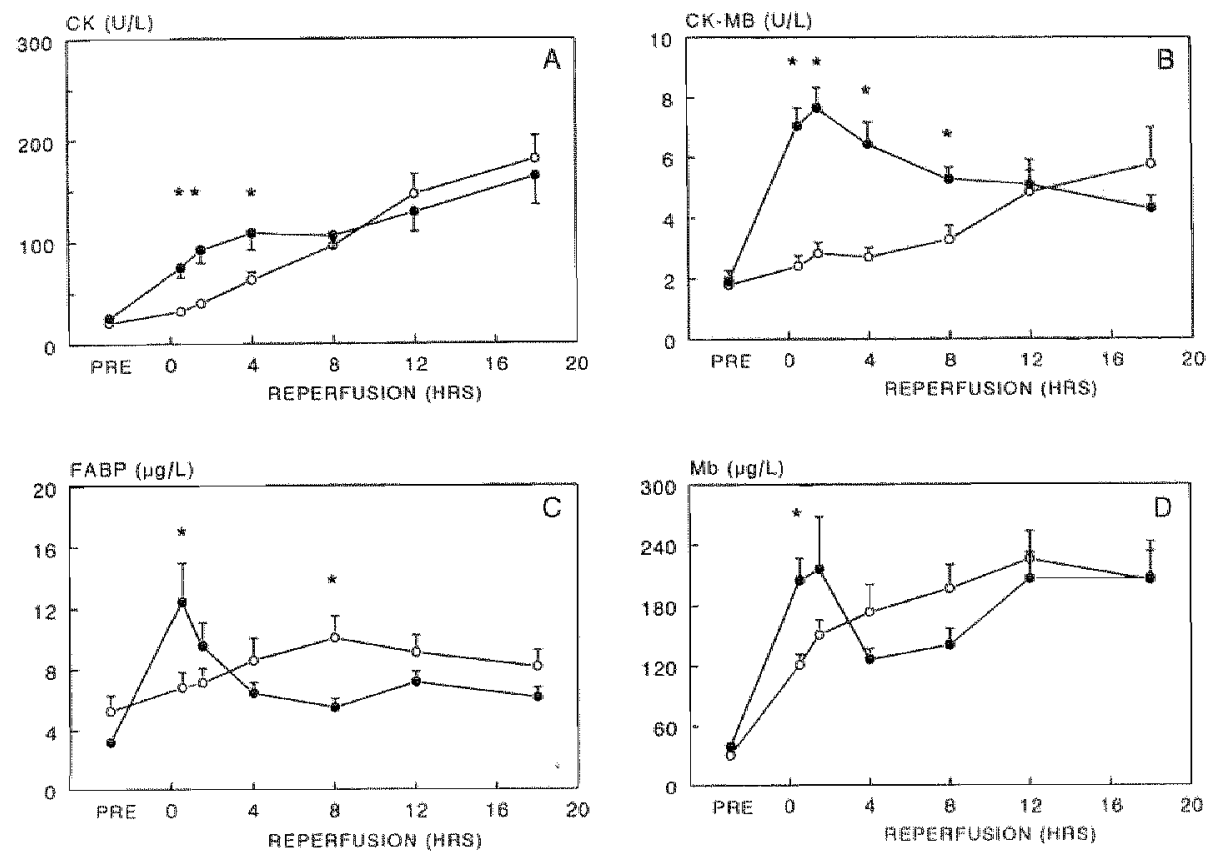

Figure 1. Mean serum concentrations of enzymes $C K$ and $C K-M B$ (pangls $A$ and $B$ ) and cardiac marker proteins FABP and myoglobin (panels $C$ and D) preoperatively, and at $0.5,4,5,4,8,12$, and 18 hours after start of repertusion in low-risk patients who underwent $\mathrm{CABG}$ with $\mathrm{CPB}$ (black circles) or without CPB (white circles). CK, creatine kinase. CK-MB, creatine kinase isoform MB. FABP, fatty acid-binding protein. PRE, preoperative at induction. " $p<0.05$, white circles ws, black circles.

\section{PMN activation and acute phase response}

Baseline levels of BPI were the same in both groups (Figure 2, panel A). BPI levels in the CPB group were elevated at 0.5 and 4 hours after reperfusion $(p<0.05$ at both timepoints), reaching peak levels of 1.7 times baseline levels at 
0.5 hour after reperfusion (data not shown). In the nonCPB group, BPI levels showed minimal changes during surgery, but increased thereafter (Figure 2, panel A). At the first postoperative day, BPI levels were significantly elevated from preoperative levels $(\mathrm{p}<0.05)$. In addition, at the first postoperative day, BPI levels were significantly higher in the nonCPB group $(\mathrm{p}<0.05)$.

The acute phase response in both patient groups was characterized by a significant increase of LBP preceded by an increase of $1 \mathrm{~L}-6$ (Figure 2, panels $\mathrm{B}$ and C). Baseline levels of IL-6 were the same in both groups (Figure 2, panel B). In the CPB group, IL-6 levels increased and peaked at 8 hours after reperfusion ( 1.8 times higher than baseline levels) $(\mathrm{p}<0.05)$. In the nonCPB group, IL-6 levels decreased during surgery and then also peaked (2.1 times higher than baseline levels) at 8 hours after reperfusion. At the first postoperative day, IL-6 levels were significantly higher in nonCPB patients (Mann Whitney U-test).

Mean preoperative plasma levels of LBP were $32.1 \pm 4 \mu \mathrm{g} / \mathrm{ml}$ in the CPB group, and $25.1 \pm 2 \mu \mathrm{g} / \mathrm{ml}$ in the nonCPB group (Figure 2, panel C). LBP levels in both groups decreased early after start of reperfusion, and subsequently were increased at 8 hours after reperfusion and on the first postoperative day. LBP levels were significantly higher in CPB patients at 4 hours after reperfusion $(p<0.05)$.
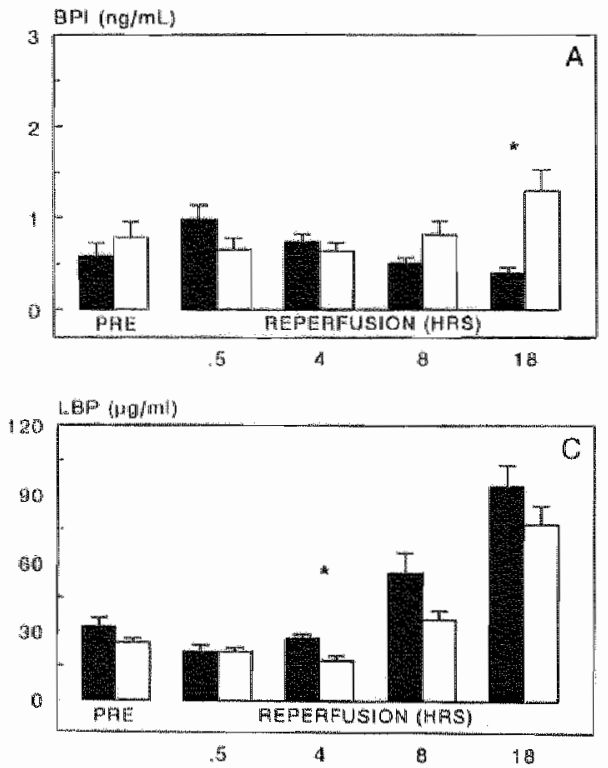

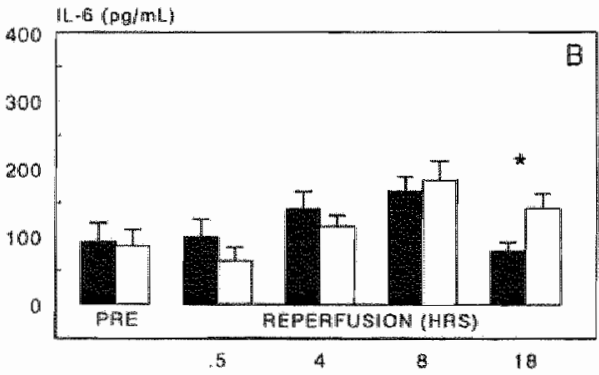

Figure 2. Mean plasma levels of BPI (panel A) . LL-6 (panel B), and LBP (panel C) in patients undergoing cardiac surgery, either with (CPB group, filled bars) or without (nonCPE group, open bars) the use of cardiopulmonary bypass. Data are presented as mean \pm SEM. indicates $p<0.05$, between groups. PAE, preoperative at induc-tion. REPERFUSION, hours after the start of reperfusion. 
Correlations of markers of myocardial tissue injury and inflammation

In order to examine the correlation of perioperative myocardial tissue injury with the inflammatory response, we first studied correlations of enzyme and cardiac marker protein levels at 0.5 hours after the start of reperfusion, with early neutrophil activation (reflected by BPI levels at 0.5 hours after reperfusion). Table 2 shows that no correlations were observed for any marker of perioperative myocardial tissue damage with early neutrophil activation.

Next, we investigated the correlation of perioperative myocardial tissue damage on the acute phase reactants. For this, we correlated enzyme and cardiac marker protein levels at 0.5 hours after the start of reperfusion with highest mean plasma levels of IL-6 and LBP. As was found for early neutrophil activation, no correlations were observed for markers of perioperative myocardial tissue damage with acute phase reactants (Table 2).

Table 2. Correlations between parameters of perioperative myocardial injury (rows) and parameters of inflammation (collums).

\begin{tabular}{llll}
\hline & BPI & IL-6 & LBP \\
\hline CK & 0.22 & 0.14 & 0.02 \\
\multirow{2}{*}{ CK-MB } & $(.26)$ & $(.47)$ & $(91)$ \\
& 0.36 & -0.16 & -0.16 \\
FABP & $(.06)$ & $(.41)$ & $(.39)$ \\
& -.14 & 0.35 & -0.24 \\
Myoglobin & $(.48)$ & $(.86)$ & $(.21)$ \\
& 0.04 & 0.21 & -0.11 \\
\hline
\end{tabular}

Values are correlation coefficients (probability values given in parenthe-ses). BPI, bactericida! permeability-increasing protein. CK, creatine kinase. CK-MB, creatine kinase isolorm ME. FABP, fatty acid-binding protein, IL-6, interleukin-6, LBP, lipopolysaccharide binding protein.

To further clarify the correlations of markers of perioperative tissue damage and inflammatory mediators, figure 3 shows scatterplots of CK-MB (as an example) and BPI, IL-6, and LBP. These plots show that whereas CK-MB platsma levels early after the start of reperfusion ( $\mathrm{x}$-axis) are higher in CPB patients (filled circles) than in nonCPB patients (open circles), BPI, IL-6, and LBP levels are within the same rang ( $y$-axis) in both groups (see also Figure 1, panel 
$B$, and Figure 2), thus ruling out a correlation between myocardial tissue injury and inflammation.
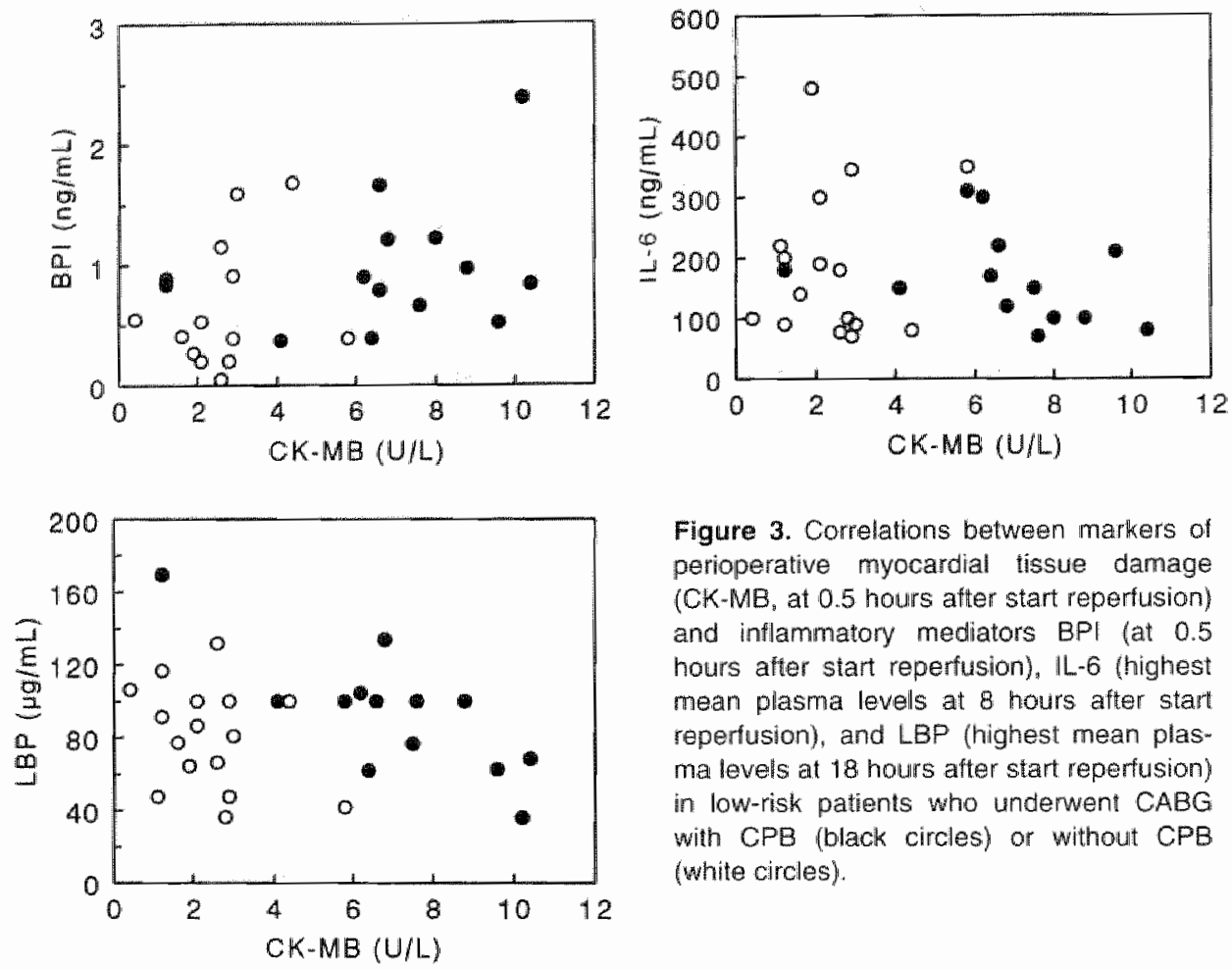

Figure 3. Correlations between markers of perioperative myocardial tissue damage (CK-MB, at 0.5 hours after start reperfusion) and inflammatory mediators $\mathrm{BP}$ (at 0.5 hours affer start reperfusion), IL-6 (highest mean plasma levels at 8 hours after staut reperfusion), and LBP (highest mean plas. ma levels at 18 hours after stat reperfusion) in low-risk patients who underwent $C A B G$ with CPB (black circlesin or without CPB (white circles).

\section{DISCUSSION}

Myocardial ischemia and reperfusion is a common occurrence in CABG patients. Reintroduction of oxygen to previously ischemic myocardium can result in irreversible tissue injury. Since ischemic myocardial damage is associated with inflammation [4-7], it is tempting to assume that such injury is associated, at least to some extent, with the systemic inflammatory response that is generally found in patients undergoing cardiac surgery. However, this hypothesis is based on the assumption that the CPB procedure, in combination with aortic cross-clamping, is the dominant inducer of systemic inflammation. Yet, in a recent study, we showed that it is not the CPB procedure (including aortic crossclamping) but the surgical procedure per se (intra-operative trauma and/or anesthetics) that predominantly induces the systemic inflammatory response to 
CABG patients [13]. Therefore, in the present study we examined whether myocardial ischemia-reperfusion injury, as occurring in CABG patients operated on with $\mathrm{CPB}$, is associated with the release of inflammatory mediators.

\section{Markers of perioperative myocardial tissue injury}

In the present study, nonCPB patients showed no immediate postoperative rise of enzyme or cardiac marker protein levels in plasma, but only a relatively slow increase. In contrast, in CPB patients all markers showed an immediate increase during the early hours after the start of reperfusion. At 0.5 hours after the start of reperfusion, plasma levels of all markers of perioperative myocardial tissue injury were significantly higher in $\mathrm{CPB}$ patients than in nonCPB patients. Therefore, we conclude that measuring activities of $\mathrm{CK}$ and $\mathrm{CK}-\mathrm{MB}$ and concentrations of FABP and myoglobin in plasma of low-risk CABG patients enables estimation of myocardial injury early after surgery. These data confirm our previous findings [1], and thus, in the present study we used plasma levels of these markers at 0.5 hours after reperfusion as measure of perioperative myocardial injury.

\section{Mediators of inflammation}

Activated neutrophils are thought to play a major role in ischemia-reperfusion injury [14]. Therefore, as in previous studies [13, 15], in the present study we used BPI as a marker of PMN activation. Patients operated on with CPB showed a significant increase in BPI levels during the early postoperative phase (Figure 2, panel A), whereas BPI levells in nonCPB patients did not increase in response to surgery. Remarkably, BPI levels in nonCPB patients were significantly increased from preoperative levels at the first postoperative day, and at this timepoint were even significantly higher than in CPB patients. In contrast to previous findings, BPI levels early after reperfusion did not significantly differ between both patient groups. The CPB patients in the present study differed from CPB patients in our previous studies, in that they had shorter CPB and aortic cross-clamping times (Table 1), and were not systemically cooled but kept at a temperature of approximately $36^{\circ} \mathrm{C}$. Therefore, the lower BPI levels in the present study might be associated with a shorter contact time with the extracorporeal circuit. Furthermore, the present data suggest that a temperature dependent factor may play a role in the activation of PMN during CABG with the use of CPB and aortic cross- 
clamping.

In agreement with previous studies $[13,15]$, increased plasma levels of ILL-6 were observed in both patient groups (Figure 2, panel B). However, unlike previous fundings, a significant delay in $\mathrm{IL}-6$ release in nonCPB patients was not found in the present study. Remarkably, as was the case for BPI levels. IL-6 levels were significantly higher at the first postoperative day in nonCPB patients. Both fundings suggest an increased inflammatory activation in nonCPB patients at the first postoperative day, and need further investigation since this may be associated with postoperative morbidity. Levels of the acute phase protein LBP were similar in both patient groups, except for LBP levels at 4 hours after the start of reperfusion (Figure 2, panel C).

Therefore, we conclude that, as we showed previously, it is predominantly the surgical procedure and not the $\mathrm{CPB}$ procedure that triggers systemic inflammation in low-risk CABG patients.

\section{Correlations of markers of myocardial tissue injury and inflammation}

As outlined above, in the present study, CPB patients showed significantly higher plasma levels of markers of perioperative myocardial tissue injury early after the start of reperfusion. Yet, the release of inflammatory mediators was similar in both patient groups. In combination with the data shown in Table 2, these data indicate that in the present group of low-risk CABG patients, perioperative myocardial tissue injury was not significantly associated to the systemic inflammatory response found in these patients.

Experimental studies on myocardial ischemia-reperfusion injury, using isolated animal hearts, suggest that nyocardial ischemia and reperfusion is associated with inflammation $[16,17]$. In the present study, in low-risk CABG patients, we did not find such an association. Possibly, the experimental findings, under ideal and standardized circumstances, may be hard to substantiate in the clinical setting. Furthermore, although enzyme and cardiac marker protein levels were significantly higher in CPB patients, duration of $\mathrm{CPB}$ and cross-clamping might not have been sufficient to elicit a considerable amount of ischemia-reperfusion induced injury [18]. Last, the release of inflammatory mediators as a result of perioperative myocardial injury may be obscured by subsequent release of these markers resulting from the intra-operative trauma. 


\section{REFERENCES}

1. Fransen EJ. Maessen JG. Hemens WT. Glatz JFC. Demonstration of ischemiareperfusion injury separate rrom postoperative infarction in coronary artery bypass graft patients. Ann Thorac Surg 1998:65:48-53.

2. Butler J, Rocker $\mathrm{GM}$, Westaby S. Inflammatory response to cardiopulmonary bypass. Ann Thorac Surg 1993:55:552-9.

3. Westaby S. Organ dysiunction after cardiopulmonary bypass. A systemic inflammatory reaction by the extracorporeal circult. intensive Care Med 1987; 13:89-95.

4. Hawkins HK, Entman ML, Zhu JY, ef al. Acute inflammatory reaction after myocardial ischemic injury and reperfusion. Development and use of a neutrophil-specific antibody. Am U Pathol 1996: 148:1957-69.

5. Engelman DT, Watanabe $M$, Maulik $N$, et al. L-arginine reduces endothelial inflammation and myocardial stunning during ischemia/reperfusion. Ann Thorac Surg 1995;60:1275-81.

6. Entman ML., Michael L. Rossen RD, et al. Inflammation in the course of early myocardial ischemia. Faseb $\mathcal{J} 1991 ; 5: 2529-37$.

7. Pannitteri G, Marino B, Campa PP, Martucoi R, Testa U. Peschle C. Interteukins 6 and 8 as mediators of acute phase response in acute myocardial infarction. Am I Cardiol 1997; $80: 622 \cdot 5$

8. Weerwind PW, Maessen JG, van Tits LJH, et al. Influence of Duraflo ll heparin-treated extracorporeal circuits on the systemic intlammatory response in patients having coronary bypass. I Thorac Cardiovasc Surg 1995; 110:1633-41.

9. Wodzig KWH, Pelsers MMAL, van der Vusse GJ, Roos W, Glatz JFC. One-step enzymelinked immunosorbent assay (ELISA) for plasma fatty acid-binding protein. Ann Clin Bio. chem 1997:34:263-8.

10. Dentener MA, Francot GJM, Smit FT, et al. Presence of bactericidal/permeability-increasing protein in disease: detection by ELISA. J Infect Dis 1995;171:739-43.

11. Dentener MA, Bazil V, Von Asmuth EJU, Ceska M, Buturman WA. Involvement of CD14 in lipopolysaccharide-induced tumor necrosis factor-a, IL-6 and IL-8 release by human monocytes and alveolar macrophages. IImmunol 1993; 150:2885-91.

12. Froon $A H M$, Dentener MA, Greve JMM, Ramsay $G$, Buurman WA. Lipopolysaccharide toxicity-regulating proteins in bacteremia. I Infect Dis 1995;171:1250-7.

13. Fransen $E$, Maessen J, Dentener M, Senden $N$, Geskes $G$, Buurman W. Systemic inflammation present in patients undergoing $C A B G$ without extracorporeal circulation. Chest 1998; 113:1290-5

14. Weiss SJ. Tissue destruction by neutrophils. N Engl J Med 1989;320 365-76.

15. Fransen EJ, Maessen JG, Dentener MA, Senden NHM, Buuman WA. Impacil of blood transfusions on inflammatory medialor release in patients undergoing cardiac surgery. Submitted 1998.

16. Tsao PS, Ma XL, Lefer AM. Activated neutrophils aggravate endothelial dystunction after repertusion of the ischemic teline myocardium. Am Heart J 1992;123:1464-71.

17. Lefer AM, Tsao PS, Lefer D.J, Ma XL. Role of endothelial dystunction in the pathogenesis of repertusion injury after myocardial ischemia. Faseb $J / 1991 \div 5: 2029 \cdot 34$.

18. Piper HM. Siegmund B, Ladilow YV, Schluter KD. Myocardial protection during reperfusion. Thorac Cardiovasc Surg 1996;44:15-9. 



\section{CHAPTER}

Preoperative soluble TNF-receptor levels as a risk factor in coronary artery bypass graft patients

Submitted for publication 


\section{ABSTRACT}

Purpose. Patients undergoing cardiac surgery show a systemic inflammatory response, which is associated with postoperative morbidity. We studied the clinical relevance of preoperatively elevated plasma levels of proinflammatory mediators in high-risk patients undergoing coronary artery bypass grafting $(n=55)$.

Methods. Interleukin(IL)-6, soluble tumor necrosis factor-alpha receptors (sTNF-R55 and sTNF-R75), and soluble leukocyte adhesion molecule (sEselectin and sICAM-1) concentrations were determined preoperatively and at several timepoints until the first postoperative day. Furthermore, patient characteristics, parameters of postoperative performance and routine clinical chemistry were recorded.

Results. From the inflammatory mediators measured, preoperative sTNFreceptor levels uniquely correlated with all preoperative patient characteristics including age, female sex, unstable angina pectoris and New York Heart Association (NYHA) class $(p<0.05)$. Patients with high baseline sTNF-receptor levels had an impaired postoperative hemodynamic recovery, a prolonged weaning from ventilation time and a higher incidence of postoperative complications. Duration of neither the cardiopulmonary bypass procedure nor aortic cross-clamping time correlated with sTNF-receptor levels. All correlations mentioned were independent to the aforementioned preoperative patient characteristics.

Conclusion. Enhanced preoperative sTNF-receptor levels represent an independent risk factor for postoperative complications after coronary artery bypass grafting.

\section{INTRODUCTION}

Since the studies by Kirklin and colleagues [1], it has been well established that plasma levels of inflammatory mediators increase following cardiac surgery [2, 3]. Although it was recently shown that postoperatively elevated cytokine levels correlated with postoperative morbidity [4-6], the clinical relevance of these elevated plasma levels still has not been fully defined. Recently, plasma levels of soluble tumor necrosis factor receptors, sTNF-R55 and sTNF-R75, at the first day after cardiac surgery have been shown to allow early prognostication of subsequent hospital course $[4]$. Since plasma levels of these receptors have also 
been shown to be elevated in candidates for coronary artery bypass grafting (CABG) [7], the question arises whether $\mathrm{CABG}$ patients with preoperatively elevated plasma levels of these receptors, have a more pronounced inflammatory response to surgery which may be associated with an impaired postoperative performance. Furthermore, since plasma levels of several other inflammatory mediators were also shown to increase after $\mathrm{CABG}[2,3]$, the additional question arises whether this phenomenon is restricted to the aforementioned sTNF-receptors or whether it also applies for other inflammatory mediators.

In the present study, we hypothesized that in potential CABG patients, preoperatively increased plasma levels of inflammatory mediators present a risk factor $[8,9]$ since the CABG procedure per se triggers inflammation $[2,3]$, and might enhance the ongoing inflammatory processes. Therefore, we investigated whether in patients undergoing $\mathrm{CABG}$ : 1) preoperative levels of inflammatory mediators correlate with postoperative levels of these mediators, 2) preoperative levels of inflammatory mediators correlate with patient characteristics which are generally accepted risk factors for postoperative complications, 3) preoperatively increased levels of inflammatory mediators correlate with an impaired postoperative performance, and 4) if such a correlation exists, whether preoperatively elevated plasma levels of inflammatory mediators are of any predictive and/or prognostic value for postoperative complications.

To this end, plasma levels of the cytokine interleukin(LL)-6, STNF-R55, sTNF-R75, and soluble leukocyte adhesion molecules E-selectin (sE-selectin) and intercellular adhesion molecule (sICAM-1), in high-risk patients undergoing $\mathrm{CABG}$ were analyzed.

\section{MATERIAL AND METHODS}

\section{Patients}

A total of 55 high-risk adult patients undergoing CABG were enrolled. Highrisk classification was based on eicher of the following selection criteria: left ventricular ejection fraction less than or equal to 0.30 and/or high dose inotropic support (greater than $7 \mu \mathrm{g} / \mathrm{kg} /$ minute dopamine or dobutamine) and $/$ or preoperative use of an intra aortic balloon pump. Age boundaries were set between 30 and 80 years. Exclusion criteria were: (1) ongoing infarction, (2) treatment with fibrinolytics within 48 hours prior to surgery, (3) treatment with anti-inflammatory drugs within preceding 2 weeks, (4) hepatic disease as indicated by 
aspartate amino transferase and alanine amino transferase levels of more than 2 times the upper limit of normal, or by bilirubin levels of more than 1.5 times the upper limit of normal, (5) severe coagulation abnormalities, and (6) parenchymal lung cisease. All subjects gave written informed consent for the study. The study was approved by the local ethical and research council.

\section{Intra-operative patient management}

Standard anesthetic (lorazepam, fentanyl citrate, sufentanil citrate, alfentanil hydrochloride, midazolam hydrochloride, pancuronium bromide) and monitoring techniques (electrocardiogram, central venous/pulmonary and arterial pressure monitoring, urinary output, rectal and skin temperature monitoring) were used. Before connection of the extracorporeal circuit for cardiopulmonary bypass (CPB), heparin was administered (300 IU/kg, Heparin Leo, Leo Pharmaceutical Products BV, Weesp, The Netherlands) in order to achieve an activated coagulation time greater than 480 seconds (Hemochron 400 , International Technidyne Corp, Edison, $\mathrm{NJ}$ ).

Specifications on the extracorporeal circulation circuit, CPB procedures and surgical procedures have been described previously [3]. Postoperative patient treatment in the coronary care unit was standardized and similar for all patients. None of the patients received thrombolytic agents.

\section{Clinical data}

The following surgery related variables were documented: CPB time, aortic cross-clamp time and number of aortocoronary bypass grafts. As indices of postoperative performance, the following variables were recorded: mean arterial pressure, cardiac index, venous oxygen saturation, diuresis, creatinine levels and time until extubation. Furthermore, the occurrence of any of the following complications was recorded: acute tubular necrosis i.e. diuresis less than 0.25 $\mathrm{mL} / \mathrm{kg} /$ hour during 6 hours or more; lung edema, shown by an intubation time of more than 18 hours and an $\mathrm{FiO}_{2}$ of more than $40 \%$ and/or a positive endexpiratory pressure of more than $50 \mathrm{~mm}$, and validated radiographically; and postoperative myocardial infarction shown by new $Q$ waves on the electrocardiogram and/or total creatine kinase isoform $\mathrm{MB}$ more than $6 \%$ of total creatine kinase, both determined on daily intervals. After this a more thorough diagnosis of postoperative myocandial infarction was established by a blinded cardiologist who compared a preoperative with postoperative electrocardio- 
grams for new persistent Q waves and ST-segment deviations ( $\geq 1 \mathrm{~mm}$ ST-segment elevation in $\geq 2 \mathrm{limb}$ leads and/or $\geq 2 \mathrm{~mm} S T$-segment elevation in $\geq 2$ precordial leads).

\section{Blood sampling}

Blood samples were taken upon induction of anesthesia (preoperative), at the start of aortic cross-clamping, at aortic unclamping and $0.5,1.5,4,8,12$ and 18 hours thereafter. Samples were collected in evacuated blood collection tubes ( 10 $\mathrm{mL}$, Monoject, Sherwood Medical, Ballymoney, U.K.) containing ethylenediaminetetraacetic acid. Immediately after sampling, blood was cooled, centrifugated at $3500 \mathrm{rpm}$ for 20 minutes and plasma samples were stored at $-70^{\circ} \mathrm{C}$ until measurements.

\section{Measurements}

Inflammatory mediators were measured with sandwich enzyme-linked immunosorbent assays (ELISA), which have been descibed elsewhere [10-12]. In short, 96-well plates (Immuno-Maxisorp; Nunc, Roskilde, Denmark) were coated with the appropiate antibodies. For IL-6, sTNF-R55, sTNF-R75, sE-selectin, and sICAM-1 measurements murine monoclonal antibody (mAb) 5E1, MR1-1, MR2-2, ENA1, and HM2 was used, respectively. Human recombinant IL-6 (a kind gift from Prof. W. Sebald, Psychiologisch-Chemisches Institut der Universität Würzburg, Germany), sTNF-R55, sTNF-R75, sE-selectin, and sICAM-1 were used for standard titration curves (these were obtained from: NSO-10 cells producing the extracellular part of TNF-R55. NSO-23 cells producing the extracellular part of TNF-R75, CHO-cells producing sE-selectin, and NSO cells designated siCAM-1/2 which were all kindly provided by Cellech, Slough, United Kingdom). Biotinylated polyclonal rabbit anti-human IL $-6 \mathrm{IgG}$, specific biotin-labeled polyclonal rabbit anti-sTNF-receptor $\operatorname{IgG}$, biotin-labeled mAb ENA2, and biotin-labeled mAb HMI were used as detection antibodies, respectively. The detection limits for the ELISA's were $10 \mathrm{pg} / \mathrm{mL}$ for the IL-6 assay, $100 \mathrm{pg} / \mathrm{mL}$ for $\$$ TNF-receptors, $1 \mathrm{ng} / \mathrm{mL}$ for sE-selectin, and $400 \mathrm{pg} / \mathrm{mL}$. for sICAM-1. Biotinylated antibodies were detected with peroxidase-conjugated streptavidin (Zymed, San Francisco, CA). Finally, 3,3'5,5'-tetramethylbenzidine (TMB; Kirkegaard \& Perry Laboratories, Gaithersburg, MD) was used ats a substrate. Photospectrometry $(450 \mathrm{~nm})$ was performed using a micro-ELISA autoreader. All plasma samples were analyzed in the same run. 


\section{Data analysis}

All data are presented as mean \pm standard error of the mean (SEM). Students' $t$ test for independent samples was used for comparisons between two variables at the same time point. A Wilcoxon Matched-Pairs Signed-Ranks Test was used for comparisons of values from one variable between two time points. A $x^{2}$-test was used to test non-numeric variables. Correlations between inflammatory mediator levels and the other parameters were tested by a Spearman analysis. Independent predictive value of sTNF-receptors and preoperative patient characteristics (age, sex, unstable angina and New York Heart Association class) on postoperative performance parameters was assessed by a stepwise multiple regression analysis. The level of significance was set at p-values less than 0.05 .

Table 1. Patient characteristics

\begin{tabular}{ll}
\hline Variable & $N=55$ \\
\hline Age (yrs.) & $64 \pm 1$ \\
Height (m.) & $1.71 \pm 0.1$ \\
Weight (kg.) & $77 \pm 2$ \\
BSA (m2) & $1.9 \pm 0.02$ \\
Sex (M/F) & $40 / 15$ \\
NYHA class (No.): & 8 \\
$\quad$ Class 2: & 21 \\
$\quad$ Class 3: & 23 \\
Class 4: & $31 / 24$ \\
Ungitalole angina (Y/N) & $97 \pm 5$ \\
CPB duration (min.) & $63 \pm 4$ \\
ACC duration (min.) & $3.4 \pm 0.2$ \\
Number of grafts. & \\
\hline
\end{tabular}

Data are presented as mean $\Perp$ SEM. ACC, aortic cross-clamping. BSA, body surface area. CPB, cardiopumonary bypass. NYHA, New York Heart Association. 


\section{RESULTS}

\section{Clinical characteristics}

The intra-operative patient characteristics are shown in Table 1. New York Heart Association (NYHA) classification data of 3 patients was ambiguous and thereby not included in the analyses.

\section{Pre, intra, and postoperative levels of inflammatory mediators}

The plasma concentrations of inflammatory mediators from time of induction until the first postoperative day are shown in Table 2.

IL-6 plasma levels increased during surgery, reached highest mean levels at 4 hours after reperfusion (16 times higher than baseline levels) and remained elevated. Preoperative IL-6 plasma levels significantly correlated with postoperative highest mean levels at 4 hours after aortic unclamping, with a correlation coefficient $0.47(\mathrm{p}<0.01)$.

Levels of both sTNF-receptors decreased early during surgery and were elevated from aortic unclamping until the first postoperative day $(\mathrm{p}<0.001$ at all time points, except for sTNF-R75 levels at aortic unclamping)(Table 2). Highest mean levels for both sTNF-receptors were reached at 4 hours after aortic unclamping. Analysis of the data showed that preoperative sTNF-receptor levels significantly correlated with postoperative highest mean levels at 4 hours after aortic unclamping. Correlation coefficients were 0.77 and 0.76 for sTNF-R55 and $s$ TNF-R75, respectively $(\mathrm{p}<0.001$ for both $s$ TNF-receptors) (Figure 1 ). Importantly, the high preoperative sTNF-receptor levels did not drive the relationship.

sE-selectin plasma levels significantly decreased during surgery, subsequently increased and reached highest mean levels at 8 hours after aortic unclamping ( 1.5 times higher than baseline levels), and remained elevaled until the first postoperative day. At 8 and 18 hours after aortic unclamping sEselectin plasma levels were significantly increased from baseline levels. Also, preoperative sE-selectin plasma levels significantly correlated with postoperative highest mean levels at 8 hours after aortic unclamping (correlation coefficient $0.74(\mathrm{p}<0.01)$ ) (data not shown).

sICAM-1 plasma levels significantly decreased during surgery, subsequently increased and reached highest mean levels at the first postoperative day $(1.1$ times higher than baseline levels) ( $p<0.001$ at all timepoints, except for $s$ ICAM1 levels at the first postoperative day $(p=0.02)$ ). In line with the findings of the 
previous inflammatory mediators, preoperative sICAM-1 plasma levels significantly correlated with postoperative highest mean levels at 18 hours after aortic unclamping, correlation coefficient 0.73 ( $\mathrm{p}<0.01$ )(data not shown).
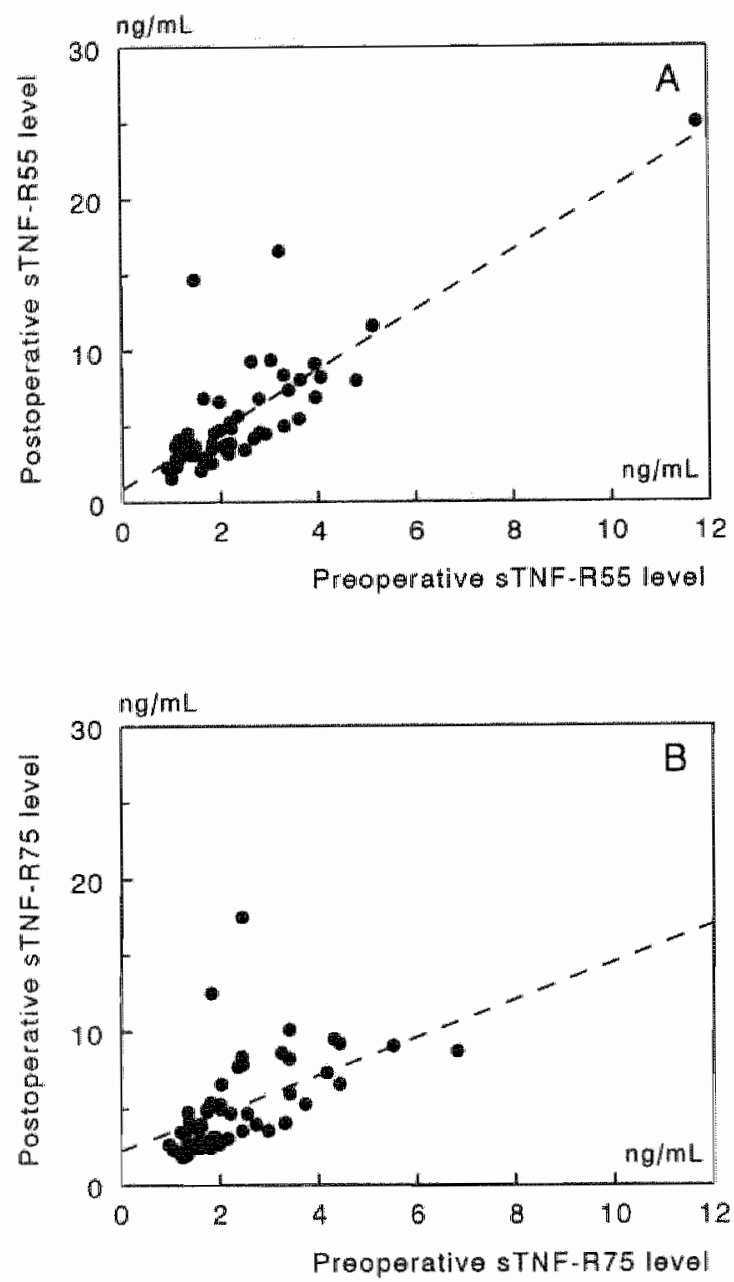

Figure 1. Preoperative sTiNif-receptor lewels correlate positively and significantly with postoperative highest mean STNFreceptor levels after coronary artery bypass grafting (STNF-R55 panel A, sitNF a 75 panel B). 
Table 2. Pre, intra, and posioperative inflammatory mediator levels in patients undergoing coronary artery bypass $(n=55)$.

\begin{tabular}{|c|c|c|c|c|c|c|c|}
\hline & Pre & $x$-on & $0 \mathrm{hrs}$ & 0.5 hrs & 4 hrs & 8 his & 18 hrs \\
\hline $\begin{array}{c}1 \mathrm{~L} \cdot 6 \\
(\mathrm{pg} / \mathrm{mL})\end{array}$ & $32 \pm 8$ & $47^{\circ} \pm 12$ & $261 \pm 160$ & $348^{\circ} \pm 179$ & $512 \pm 156$ & $496^{\circ}+69$ & $296^{\circ} \pm 33$ \\
\hline $\begin{array}{c}\text { STNF-A55 } \\
(n g / m L)\end{array}$ & $2.4 \div 0.2$ & $1.9 \pm 0.2$ & $3.0^{\circ} \pm 0.3$ & $4.0^{\circ} \pm 0.3$ & $5.6^{\circ} \pm 0.5$ & $5.2 \pm 0.5$ & $5.0^{\circ} \pm 0.5$ \\
\hline $\begin{array}{c}\text { STNF-R75 } \\
\text { (ng/mL) }\end{array}$ & $2.7 \pm 0.3$ & $1.9^{\circ} \pm 0.2$ & $2.9 \pm 0.3$ & $3.9^{\circ} \pm 0.4$ & $5.6^{*}+0.5$ & $5.4^{2}+0.6$ & $5.2^{\circ} \pm 0.5$ \\
\hline $\begin{array}{c}\mathrm{sE-selectin} \\
(\mathrm{ng} / \mathrm{mL})\end{array}$ & $29 \pm 3$ & $20^{\circ} \pm 2$ & $22^{\prime \prime}+2$ & $22^{\circ} \pm 2$ & $30 \pm 3$ & $444^{\prime \prime} \pm 5$ & $43^{\prime \prime} \pm 4$ \\
\hline $\begin{array}{c}\text { slCAM-1 } \\
\text { (ng/mL) }\end{array}$ & $50 \pm 4$ & $29^{\circ} \pm 2$ & $33^{\prime \prime} \pm 3$ & $34 \pm 2$ & $36^{\circ} \pm 2$ & $42^{\circ} \pm 3$ & $55^{\prime \prime} \pm 4$ \\
\hline
\end{tabular}

Data are presented as mean \pm SEM. Pre, preoperative. $x$-on, start of aortic crossclamping. 0 hrs, 0.5 hrs, 4 hrs, $8 \mathrm{hrs}$ and $18 \mathrm{hrs}$, hours after aortic unclamping. "indicates $p<0.05$ from pre.

Correlations of preoperative inflammatory mediator levels with clinical parameters

Next the correlation of preoperative inflammatory mediator levels with patient characteristics was investigated. Preoperative IL-6 and sE-selectin levels significantly correlated with the female gender, but not with any other variable studied. SICAM-1 significantly correlated with the presence of unstable angina pectoris (Table 3). Also, preoperative sTNF-receptors correlated posilively and significantly with unstable angina. Furthermore, these receptors correlated with NYHA class, age and the female gender (Table 3). No correlations were observed for any inflammatory mediator with preoperative hemodynamic parameters (mean arterial pressure, cardiac index and venous oxygen saturation).

We also investigated the correlation of preoperative inflammatory mediator levels with postoperative performance parameters (Table 4). The analysis revealed that preoperative IL-6 and $s E$-selectin levels significantly correlated with cardiac index at 12 hours after aortic unclamping. In addition, preoperative IL-6 levels also correlated significantly with diuresis until 12 hours after aortic unclamping ( $p=0.03)$ and time until weaning from ventilation $(p=0.01)$. 
Preoperative sICAM-1 levels significantly correlated with creatinin levels at the first postoperative day. Conversely, preoperative sTNF-receptor levels, significantly correlated with all postoperative hemodynamic parameters (mean arterial pressure, cardiac index, and venous oxygen saturation), indices of renal function (diuresis, creatinin and acute tubular necrosis) and lung function (extubation time and lung edema). Like the other inflammatory mediators, preoperative sTNF-receptor levels did not correlate with the occurrence of postoperative myocardial infarction.

Table 3. Correlations between preoperative inflarnmatory mediator levels and preoperative patient characteristics $(n=55)$

\begin{tabular}{lccccccc}
\hline & Age & Sex & $\begin{array}{c}\text { Unstable } \\
\text { angina }\end{array}$ & $\begin{array}{c}\text { NYHA } \\
\text { class }\end{array}$ & $\begin{array}{c}\text { preop } \\
\text { MAP }\end{array}$ & $\begin{array}{c}\text { preop } \\
\mathrm{Cl}\end{array}$ & $\begin{array}{c}\text { preop } \\
\mathrm{SvO}_{2}\end{array}$ \\
\cline { 2 - 7 } IL-6 & .16 & .32 & .23 & .09 & .04 & -.06 & -.10 \\
STNF-R55 & $(.24)$ & $(.02)$ & $(.09)$ & $(.52)$ & $(.80)$ & $(.69)$ & $(.68)$ \\
& .35 & .33 & .45 & .37 & -.06 & .04 & -.16 \\
STNF-R75 & $(.010)$ & $(.015)$ & $(.001)$ & $(.006)$ & $(.66)$ & $(.79)$ & $(.50)$ \\
& .39 & .27 & .41 & .37 & .03 & -.02 & -.33 \\
SE-Selectin & $(.003)$ & $(.051)$ & $(.002)$ & $(.007)$ & $(.81)$ & $(.91)$ & $(.16)$ \\
& $(.21$ & -.29 & -.05 & -.14 & -.07 & .08 & -.12 \\
SICAM-1 & $(.12)$ & $(.03)$ & $(.70)$ & $(.31)$ & $(.62)$ & $(.57)$ & $(.61)$ \\
& -.23 & -.23 & -.27 & -.18 & .06 & -.02 & -.41 \\
& $(.09)$ & $(.09)$ & $(.04)$ & $(.19)$ & $(.66)$ & $(.87)$ & $(.07)$ \\
\hline
\end{tabular}

Values are correlation coefficients (probability values given in parentheses). $\mathrm{Cl}_{\text {, }}$ cardiac index. MAP, mean arterial pressure. NYHA, New York Heart Association. preop, preoperative. $\mathrm{SWO}_{2}$ venous oxygen saturation.

Previous studies showed that STNF-receptor levels may increase as a result of poor renal function [13]. Therefore, we tested whether preoperative renal function correlated with preoperative sTNF-receptor levels, and consequently interfered with the correlations that we observed between STNF-receptor plasma levels and other variables. Data analyses revealed that preoperative sTNFreceptor levels did not correlate with preoperative creatinin levels (data not shown). Moreover, a stepwise multiple regression analysis including the variables age, sex, unstable angina, NYHA class and preoperative sTNF-receptor levels, showed that preoperative sTNF-R55 and STNF-R75 were the most important independent variables predicting creatinin levels at the first postope- 
Table 4. Correlations between preoperative inflammatony mediator levels and postoperative periormance parameters.

\begin{tabular}{|c|c|c|c|c|c|c|c|c|c|}
\hline & $\begin{array}{l}\text { MAP } \\
12 \text { hrs }\end{array}$ & $\begin{array}{c}\text { Cl } \\
12 \text { hrs }\end{array}$ & $\begin{array}{l}\mathrm{SwO}_{2} \\
12 \mathrm{hrs}\end{array}$ & $\begin{array}{c}\text { Diuresis } \\
12 \text { hrs }\end{array}$ & $\begin{array}{l}\text { Creatinin } \\
y^{\text {st }} \text { po day }\end{array}$ & $\begin{array}{c}\text { ATN } \\
5 \text { days }\end{array}$ & $\begin{array}{l}\text { Extuba- } \\
\text { tion time }\end{array}$ & $\begin{array}{l}\text { Lung } \\
\text { edeme }\end{array}$ & $\begin{array}{c}\text { MI } \\
5 \text { days }\end{array}$ \\
\hline \multirow[t]{2}{*}{$14-6$} & -.20 & -.34 & .05 & -.29 & .04 & .03 & .33 & .17 & -.08 \\
\hline & $(14)$ & $(.01)$ & $(83)$ & $(.03)$ & $(.80)$ & $(.85)$ & $(.01)$ & $(22)$ & $(.57)$ \\
\hline \multirow[t]{2}{*}{ STNF-R55 } & -.12 & -.28 & .42 & -.34 & .30 & .35 & .46 & .38 & .08 \\
\hline & $(.037)$ & $(.037)$ & $(.047)$ & $(.012)$ & $(.028)$ & $(.008)$ & $(.000)$ & $(.004)$ & $(.57)$ \\
\hline \multirow[t]{2}{*}{ STNF“R75 } & -.27 & -.35 & .63 & -.46 & .33 & .30 & .41 & .40 & .07 \\
\hline & $(.047)$ & $(.009)$ & $(.001)$ & $(.000)$ & $(.016)$ & $(.028)$ & $(.002)$ & $(.002)$ & (.59) \\
\hline \multirow[t]{2}{*}{ sE-selectin } & .01 & .35 &. .22 & .19 & -.02 &. .15 & -.17 & .08 & .20 \\
\hline & $(93)$ & $(.01)$ & $(.31)$ & $(.17)$ & $(91)$ & $(.28)$ & $(.20)$ & $(.55)$ & $(.15)$ \\
\hline \multirow[t]{2}{*}{ SICAM-1 } & -.02 & .16 & -.30 & .10 & .28 & .07 & .09 & .12 & .15 \\
\hline & $(.90)$ & $(.26)$ & $(.16)$ & $(.46)$ & $(.04)$ & $(.60)$ & $(.50)$ & $(.39)$ & $(.27)$ \\
\hline
\end{tabular}

Values are correlation coefficients (probability values given in parentheses). ATN, acute tubular necrosis. $\mathrm{Cl}$, cardiac indax. MAP, mean arterial pressure. MI 5 days, occurrence of postoperative myocardial infarction within 5 days postoperatively. po postoperative. $\mathrm{SvO}_{2}$, venous oxygen saturation. 12 hrs, until 12 houl's postoperatively.

rative day $(p<0.001$ for $s T N F-R 55$, and $p<0.01$ for $s T N F-R 75)$, the occurrence of acute tubular necrosis within 5 days after surgery $(p<0,001$ for both sTNF. receptors), time until extubation ( $\mathrm{p}<0.001$ for both $s \mathrm{TNF}$-receptors) and lung edema $(p<0.01$ for $s T N F-R 55$, and $p<0.001$ for $s T N F-R 75)$. Furthermore, preoperative sTNF-R75 was found to be an independent variable predicting venous oxygen saturation at 12 hours after aortic unclamping $(\rho<0.01)$.

\section{DISCUSSION}

In patients undergoing cardiac surgery a systemic inflammatory response is seen after surgery which is associated with postoperative morbidity [14-15]. We hypothesized that the great variability found in the intensity of this response might be associated with differences in the preoperative inflammatory state. For the present study, high-risk patients that underwent $\mathrm{CABG}$ were selected. Among the inflammatory mediators measured, preoperative sTNF-receptor 
levels in our patients uniquely correlated with known risk factors for postoperative morbidity (Table 3 ). New findings from our study show that preope-rative inflammatory mediator levels correlated significantly with postoperative inflammatory mediator levels. More importantly, among "classic" risk factors, preoperative STNF-receptors were the most important independent variables predicting postoperative performance.

Cytokine levels in most studies show a large patient-to-patient variability in all patients or in particular patient groups $[7,16]$. Enhanced levels of both \$TNF-receptors have been described in patients with various types of diseases $[7,17,18]$. Despite the use of a sellected group of patients in the present study, a large variability in preoperative sTNF-receptor levels was found (sTNF-R55 ranged from 0.91 to $11.78 \mathrm{ng} / \mathrm{mL}$, and sTNF-R75 from 0.91 to $16.98 \mathrm{ng} / \mathrm{mL}$ ). However, the STNF-receptor levels were shown to correspond strongly to preoperative patient characteristics (Table 3). The positive correlation between both sTNF-receptors and age, and the positive correlation between STNF-R55 and the female sex are in correspondence with the fact that both advanced age and female sex are generally accepted risk factors for complications in patients undergoing $\mathrm{CABG}$. Interestingly, a significant correlation between preoperative levels of both sTNF-receptors and unstable angina was found, indicating that preoperatively elevated sTNF-receptors reflect acute coronary syndromes. This finding is in line with studies which showed that plasma levels of the acute phase reactant $C$-reactive protein (which also reflects inflammatory activity) are elevated in patients with unstable angina pectoris $[19,20]$.

As mentioned earlier, patients undergoing cardiac surgery show postoperative signs of inflammation, which are characterized by sepsislike symptoms, hemodynamic instability and/or organ failure [15, 16]. A major finding of our present study is the observation that preoperative inflammatory mediator levels significantly correlate with postoperative inflammatory mediator levels. In previous studies it has been shown that the ability of a cell to synthesize proand anti-inflanmatory mediators is influenced by its previous state of activation 1211. Therelore, in patients with preoperatively elevated plasma levels of sTNFreceptors, the additional inflammatory stimulus induced by the surgical proce dure might result in a temporary disturbance of the balance between pro- and anti-inflammatory mediators, which may postoperatively result in hemodynamic instability and/or organ failure. In the present study this was shown by the correlations between preoperative sTNF-receptor levels and postoperative cardiac performance (shown by mean arterial pressure, cardiac index), lung function (shown by extubation time and lung edema) and renal function (shown by 
acute tubular necrosis, creatinine and diuresis)(Table 4). Therefore, whatever the underlying mechanisms, patients with preoperatively elevated sTNF-receptor levels should be recognized as being at increased risk for postoperative complications.

In the present study with a selected patient population we did not find a correlation between variables of the $\mathrm{CPB}$ procedure (duration of $\mathrm{CPB}$ and aortic cross clamping) with either postoperative performance parameters or with postoperative inflammatory mediator levels (data not shown) as was reported by others $[1,22]$. Therefore, a putative enhancement of STNF-receptor levels by duration of $\mathrm{CPB}$ or aortic cross clamping did not determine the significant correlation between sTNF-receptor levels and postoperative performance. Furthermore, as mentioned earlier, we showed in a previous study that the acute phase response in $\mathrm{CABG}$ patients is induced by the surgical procedure and not by the $\mathrm{CPB}$ procedure [2]. Therefore, based on these data we conclude that in patients undergoing $\mathrm{CABG}$, mainly preoperative patient characteristics, including plasma levels of inflammatory mediators, and not CPB related parameters determine the perioperative induced inflammatory response to surgery and postoperative performance.

This study shows that, unlike other inflammatory mediators, preoperative sTNF-receptor levels in patients scheduled for coronary artery bypass grafting represent a strong independent risk factor for postoperative complications. The positive correlation demonstrated in this study between preoperative sTNFreceptor levels and postoperative performance indicates that the prognosis for surgery may be predicted by preoperatively measuring these markers. Further studies are aimed at determining threshold levels for STNF-receptors, so that preoperative STNF-receptor levels indeed can be implemented in the risk stratification for $\mathrm{CABG}$.

The preoperative correlation between risk factors and STNF receptors indicates that preoperative measurement of sTNF-receptors might have clinical relevance in the assessment of disease status. The exact mechanism of sTNFreceptor release prior to, and in response to, cardiac surgery should be studied, since these receptors uniquely correlated with postoperative performance.

In the future, patients who preoperatively show signs of intlammation, as reflected by elevated sTNF-receptors, might be selected for treatment with novel selective anti-inflammatory therapeutic agents before surgery, in order to reduce the risk of postoperative complications. So far, appropriate treatments are not available but the introduction of newly developed drugs such as phosphodiesterase 4 inhibitors, which suppress pro-inflammatory TNF- $\alpha$ synthesis 
and/or enhance anti-inflammatory interleukin-10 release, might be promising for future clinical use [23].

\section{REFERENCES}

1. Kindlin JK, Blackstone EH, Kirklin JW. Cardiopulmonary bypass: studies on its damaging effects. Blood Purification 1987,5:168-78.

2. Fransen EJ, Maessen JG, Dentener MA. Senden NHM, Geskes GG, Buurman WA. Systemic inflammation present in patients undergoing $C A B G$ without extracorporeal circulation. Chest 1998;113:1290-5.

3. Weerwind PW. Maessen JG, van Tits L.JH $H_{1}$ et al. Influence of Durafto il heparim-treated extracorporeal circuits on the systemic inflammatory response in patienis having coronary bypass. J Thorac Cardiovasc Surg 1995:110:1633-41.

4. Pilz G, Fraunberger P. Appel $\mathbb{R}$, et al. Early prediction of outcome in scoremidentified, postcardiac surgical patients at high risk for sepsis, using saluble tumor necrosis factor receptor-p55 concentrations. Crit Care Med 1996;24:596-600.

5. Dong MC, Dasch B, Erren $M_{\text {, Mollhoff }} T$, Scheid HH. Impact of left ventricular dysfinction on cytokines, hemodynamics, and outcome in bypass grafting. Ann Thorac Surg 1996; 62:184-90.

6. Hennein $H A$, Ebba $H$, Rodriquez $J \mathrm{~L}$, et al. Fellationship of the prointlammatory cytokines to myocardial ischemia and dysfunction after uncomplicated coronary revascularization. $J$ Thorac Cardiovasc Surg 1994;108:626-35.

7. Ferrari $\mathrm{A}$, Bachetti $\mathrm{T}$, Confortini $\mathrm{R}$, et al. Tumor necrosis factor soluble receptors in patients with various degrees of congestive heart faillure. Circulation 1995;92:1479-86.

8. Packer $M$. Is tumor necrosis factor an important neurohormonal mechanism in chronic heart fallure? Circulation 1995;92:1379-82.

9. Libby $P$, Mitchell RN. Cytokines score a knockout. Harnessing gene targeting to gain insight into the pathogenesis of myocarditis. Circulation 1997;95:551-2.

10. Dentener MA, Bazill V, Von Asmuth EJU, Ceska M, Buurman WA. Inwolvement of CD14 in lipopolysaccharide-induced tumor necrosis factor-a, IL-6 and IL-B release by human monocytes and alveolar macrophages. J Immunol 1993;150:2885-91.

11. Leeuwenberg JFM, Jeunhomme TMAA, Butuman WA. Slow release of soluble TNF receptors by monocyles in vitro. J Iinmunal 1994; 152: 4036-43.

12. Bouma M. Laan M. Dentener M. Buurman W. Analysis of soluble adhesion molecules. In: Johnstone A, Tuner M, eds. Immunochemistry 2: A Practical Approach. Oxford: Oxford University Press, 1997:181-96.

13. Leeuwenberg JF, Froon AH, Vaessen LM, at al. Soluble tumor necrosis lactor-receptors are not a useful marker of acute allograft rejection: a study in patients with renal or cardiac allografts. Transpl Int 1995;8: 459-65.

14. Butler J, Rocker GM, Westaby S. Inflammatory response to cardiopumonary bypass. Ann Thorac Surg 1993;55:552-9.

15. Holzheimer RG, Molloy RG, Gorlach H, Wilkert S, Hehrlein F, IL-6 and TNF alpha release in association with neutrophil activation after cardiopulmonary bypass surgery. Iniection 1994:22:37-42.

16. Cremer $\rfloor_{n}$ Martin $M$. Redl $H_{0}$ at al. Systemic inflammatory response syndrome after Cardiac operations. Ann Thorac Surg 1996;61:1714-20.

17. Aderka D. Engeimann $H$, Homik $V$, et al. Increased serum levels of soluble receptors for tumor necrosis factor in cancer patients. Cancer Res 1991;51:5602-7.

10. Demz $H$, Orth $B$. Weiss $G$, ot al. Serum soluble tumor necrosis factor 55 is increased in patients with haematological neoplasia and is associated with immune activation and 
weight loss. Eur J Cancer 1993:29a:2232-5.

19. Berk BC. Weintraub WS, Alexander RW. Elewation of C-reactive protein in "active" coronary artery disease. Am J Cardiol 1990;65:168-72.

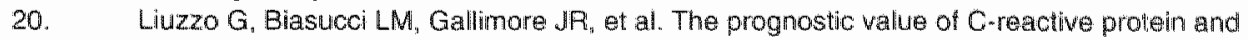
serum amyloid A protein in severe unstable angina. N Engl J Med 1994:331:417-24.

21. Szabo G, Kodys K, Miller-Graziano CL. Elevated monocyte interleukin-6 (IL-6) production in immunosuppressed trauma patients. I. Role of FogRI cross-linking stimulation. I Clin Immunol 1991;11:326-35.

22. Casey LC. Role of cytokines in the pathogenesis of cardiopulmonary-induced multisystem organ failure. Ann Thorac Surg 1993;56:S92-S96.

23. Teixeira MM, Gristwood RIN, Cooper $N$. Hellewell PG. Phospho-dlesterase (PDE) 4 inhibitors: anti-infiammatory drugs of the future? Trends Pharmacol Sci 1997; 18:164-74. 

CHAPTER

通

Enhanced preoperative C-reactive protein plasma levels as a risk factor for infections after cardiac surgery

Published in: The Annals of Thoracic Surgery 1999;67:139-145 


\section{ABSTRACT}

Purpose. We examined the possible predictive role of preoperative C-reactive protein (CRP) levels for postoperative infections in patients undergoing cardiac surgery.

Methods. CRP levels were determined on the day before surgery, and on days 1 to 4 and 6 after surgery in 593 consecutive patients. Furthermore, we documented infectious disease related data.

Results. Patients in whom an infection developed during the postoperative course $(n=87)$ had significantly higher CRP levels on the day before surgery, $17.8 \pm 3.9 \mathrm{mg} / \mathrm{L}$ vs. $7.7 \pm 0.7 \mathrm{mg} / \mathrm{L}$ ( $p<0.001$ ), and on day 4 and 6 after surgery. The incidence of postoperative infections was significantly higher in patients with enhanced preoperative CRP levels than in those with normal preoperative CRP levels, $25.3 \%$ vs. $11.2 \%$, respectively $(p<0.001)$. Furthermore, patients with enhanced preoperative CRP levels had a significantly longer postoperative hospital stay than those with normal preoperative CRP levels, $10.8 \pm 1.2$ vs. 7.8 \pm 0.3 days $(p<0.001)$. Multivariate analysis including "classic" risk factors and enhanced preoperative CRP levels, demonstrated that preoperatively enhanced CRP was the most important variable predicting postoperative infection $(\mathrm{OR}=2.7 ; 95 \% \mathrm{Cl}=1.7$ to $4.3 ; \mathrm{p}<0.001)$.

Conclusions. Patients with enhanced preoperative CRP levels are at increased risk for postoperative infections. Therefore, preoperative measurement of CRP might be a useful, predictive marker in risk stratification for postoperative infections in patients scheduled for cardiac surgery.

\section{INTRODUCTION}

C-reactive protein (CRP) is regarded as the prototypal acute phase reactant in humans. CRP is a sensitive, although nonspecific, marker of inflammation. Circulating plasma levels of CRP were shown to be increased in th variety of clinical and pathological situations $[1,2]$. In some patients with angina pectoris, enhanced CRP levels recently have been demonstrated [3]. Because these patients are potential candidates for cardiac surgery, some patients will be operated with preoperatively enhanced CRP levels. Postoperatively enhanced CRP levels in cardiac surgical patients have been shown to correlate with the incidence of infections [4-6]. However, whether there is a relationship between 
preoperatively enhanced CRP levels and the occurrence of postoperative infections after cardiac surgery has yet to be established.

Although CRP measurements have been used for early detection of postoperative complications, preoperative CRP levels have not been used as a risk factor for postoperative complications. The impact of enhanced preoperative CRP levels on the incidence of postoperative infections in patients undergoing cardiac surgery is therefore unknown. Because infections are important determinants of morbidity and mortality in these patients [7], markers identifying patients at risk for postoperative infections are valuable for risk stratification. We hypothesized that patients with enhanced preoperative CRP levels undergoing cardiac surgery are at increased risk for the development of postoperative infections.

\section{MATERIAL AND METHODS}

\section{Study Population}

In this study 593 consecutive patients undergoing cardiac surgery were included. None of the patients had clinical signs of infection before surgery. All operations were performed by members of the attending staff of the Department of Cardiopulmonary Surgery. The study was performed according to the rules of the local ethical and research council.

Intra-operative patient management

Standard anesthetic (lorazepam, fentanyl citrate, sufentanil citrate, alfentanil hydrochloride, midazolam hydrochloride, pancuronium bromide) and monitoring techniques (electrocardiogram, central venous/pulmonary and arterial pressure monitoring, urinary output, rectal and skin temperature monitoring) were used. Before connection of the extracorporeal circuit for cardiopulmonary bypass (CPB), heparin was administered (300 IU/kg, Heparin Leo, Leo Pharmaceutical Products BV, Weesp, The Netherlands) in order to achieve an activated coagulation time greater than 480 seconds (Hemochron 400, International Technidyne Corp, Edison, NJ, USA). Specifications on the extracorporeal circulation circuit, $\mathrm{CPB}$ procedures and surgical procedures have been described previously [8]. Postoperative patient treatment in the coronary care unit was standardized and similar for all patients. 
Clinical data

The following variables were recorded: age, sex, angina pectoris type (stable vs. unstable), diabetes mellitus, preoperative use of intra-aortic balloon pump, type of procedure, CPB time, aortic cross-clamp time, incidence of postoperative infection, length of postoperative hospitalization and mortality.

Definitions for infections were derived from Garner and colleagues [9]. Infectious disease related data, including reports of microbiologic studies, were recorded in the centrall computer system of our department.

\section{Measurements}

Blood samples were taken on the day before surgery and on daily intervals on postoperative days 1 to 4, and 6. All samples were collected in Corvac integrated serum separator tubes $(10 \mathrm{~mL}$, Corvac, Sherwood Medical, St. Louis, MO, USA). The CRP concentrations were measured using a turbidimetric method. A CRP reagent (Beckman test kit number 445855 ), in conjunction with the Synchron CX Systems CX CRP Calibrator Set (Beckman, number 445915) (Beckman Instruments, Inc, Brea, CA, USA) was used for the quantitative determination of CRP in serum. The normal reference values in 50 healthy volunteers in our hospital was $4.8 \pm 0.4 \mathrm{mg} / \mathrm{L}$.

\section{Data analysis}

All data are presented as mean \pm standard ertor of the mean (SEM). Students' $t$ test for independent samples was used for comparisons between two variables at the same time point. A Wilcoxon Matched-Pairs Signed-Ranks Test was used for comparisons of values from one variable between two time points. A $\chi^{2}$-test was used to test non-numeric variables. Independent predictive value of each variable was assessed by multiple regression analysis. The level of significance was set at p-values lower than 0.05 .

\section{RESULTS}

\section{Patients}

A total of 593 consecutive patients who had cardiac surgery were evaluated. The mean age of the patients was $63 \pm 0.4$ years (range 28 to 84 years); 409 
(69\%) patients were men and $184(31 \%)$ patients were women. The surgical procedures included $443(74.7 \%)$ coronary artery bypass (CABG) operations, $86(14.5 \%)$ valve operations, $48(8.1 \%) \mathrm{CABG}$ combined with valve operations, and $16(2.7 \%)$ miscellaneous heart operations. Mean duration of cardiopulmonary bypass was $95 \pm 2$ minutes and mean duration of aortic cross-clamping was $61 \pm 1$ minutes. Only 7 patients had a preoperatively introcluced intra-aortic balloon pump. Therefore, this variable was not used in statistical analyses.

\section{C-reactive protein levels}

On the day before surgery, the mean CRP level was $9.4 \pm 0.8 \mathrm{mg} / \mathrm{L}$ (median value $3 \mathrm{mg} / \mathrm{L}$ ). Cardiac surgery induced a sharp increase in CRP levels to $80.9 \pm$ $1.4 \mathrm{mg} / \mathrm{L}$ on the first postoperative day. CRP levels peaked on the third postoperative day $(203.4 \pm 8.7 \mathrm{mg} / \mathrm{L})$ and declined thereafter toward day six after surgery $(77.9 \pm 2.8 \mathrm{mg} / \mathrm{L})$.

\section{Postoperative infections}

According to our definitions $87(14.7 \%)$ patients developed at least one postoperative infection. Infections included pulmonary infections, urinary tract infections, sternal wound infections, surgical wound infections, sepsis or a combination of these. Patients with an infection during the postoperative course had significantly higher preoperative CRP levels, $17.8 \pm 3.9 \mathrm{mg} / \mathrm{L}$ vs. $7.7 \pm 0.7$ $\mathrm{mg} / \mathrm{L}(\mathrm{p}<0.001)$ (Figure 1).

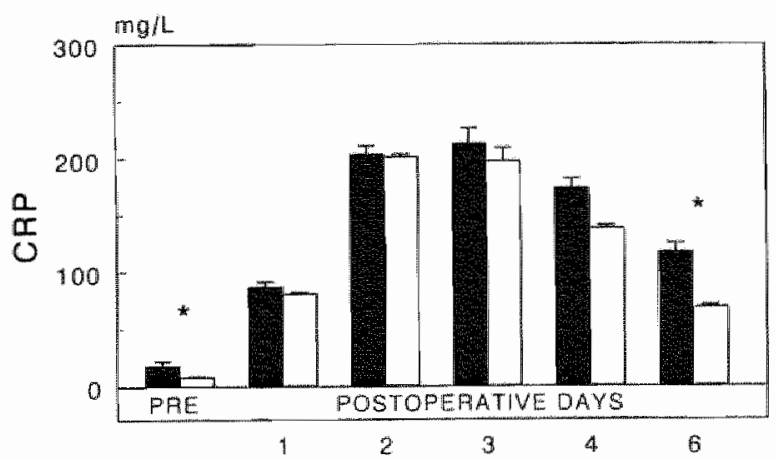

Figure 1. Mean plasma levels of C-reactive protein in cardiac surgical patients who did (filled bars) or did not (open bars) have an infection during the postoperative course. Data are presented as mean $\pm S E M$. indicates $p<0.05$, between groups. 
Furthermore, CRP levels in patients who had an infection were significantly higher on day $4(173.4 \pm 8 \mathrm{vs} .137 .3 \pm 2.8 \mathrm{mg} / \mathrm{L}, \mathrm{p}<0.001)$ and on day $6(116.5$ \pm 7.8 vs. $67.7 \pm 2.4 \mathrm{mg} / \mathrm{L}, \mathrm{p}<0.001$ ) after surgery (Figure 1).

Patients developing an infection had a significantly longer postoperative hospital stay than patients without an infection (19.4 \pm 2.2 vs. $6.9 \pm 0.2$ days) $(\mathrm{p}<0.001)$.

In the total patient group, $10(1.7 \%)$ patients died during hospitalization, all of whom had at least one infection.

\section{Enhanced vs. "normal" preoperative CRP levels}

To test the predictive value of preoperative CRP levels, we divided the patient population into two groups, as described previously [3]. To this end we defined quartiles on the basis of the distribution of preoperative CRP levels. We compared patients having preoperative CRP levels in the upper quartile $(>8 \mathrm{mg} / \mathrm{L}$, "enhanced"), with patients in the three lower quartiles combined $(\leq 8 \mathrm{mg} / \mathrm{L}$, "normal").

Table 1. Clinical characteristics of patients with normal preoperative CAP levels and patients with erihanced preoperative CRP levels.

\begin{tabular}{lccc}
\hline Variable & $\begin{array}{c}\text { Normal CRP } \\
(n=447)\end{array}$ & $\begin{array}{c}\text { Enhanced CRP } \\
(n=146)\end{array}$ & $p$ Value \\
\hline Age (y) & $62.3 \pm 0.5$ & $64.9 \pm 0.8$ & $<0.01$ \\
Male/Female (\%) & $69.4 / 30.6$ & $67.8 / 32.2$ & $\mathrm{~ns}$ \\
Unstable angina (\%) & 1.8 & 9.6 & $<0.001$ \\
Diabetos mellitus (\%) & 11.1 & 11.0 & $\mathrm{~ns}$ \\
Prooperative intra-aortic balloon pump (\%) & 0.2 & 4.1 & $<0.001$ \\
Type of operation (\%) & & & \\
CABG & 75.6 & 71.9 & $\mathrm{~ns}$ \\
Valwe surgery & 1.4 .3 & 15.1 & $\mathrm{~ns}$ \\
CABG + valwe surgery & 7.4 & 10.3 & $\mathrm{~ns}$ \\
Miscellaneous & 2.7 & 2.7 & $\mathrm{~ns}$ \\
Cardiopulmonary bypass duration (min) & $94 \pm 2$ & $100 \pm 4$ & $\mathrm{~ns}$ \\
Aortic cross-clamping duration (min) & $60 \pm 1$ & $65 \pm 3$ & $\mathrm{~ns}$ \\
Postoperalive infection (\%) & 11.2 & 25.3 & $<0.001$ \\
Postoperative hospitalization (days) & $7.8 \pm 0.3$ & $10.8 \pm 1.2$ & $<0.001$ \\
Hospital mortality (\%) & 1.3 & 2.7 & $\mathrm{~ns}$ \\
\hline
\end{tabular}

Data are shown as mean $\pm S E M$, or as percentage of group total. 
Patients in the upper quartile had significantly higher preoperative CRP levels than patients in the lower quartiles $(28.3 \pm 2.8$ vs. $3.2 \pm 0.1 \mathrm{mg} / \mathrm{L})(\mathrm{p}<0.001)$. Furthermore, patients in the upper quartile had significantly higher CRP levels on postoperative day $1(95 \pm 3.4 \mathrm{vs} .76 \pm 1.4 \mathrm{mg} / \mathrm{L})$, day $2(221.8 \pm 5.1 \mathrm{vs}$. $193.8 \pm 2.7 \mathrm{mg} / \mathrm{L})$, day $3(243.7 \pm 15.2$ vs. $182.2 \pm 9.6 \mathrm{mg} / \mathrm{L})$, day $4(163.7 \pm$ 5.9 vs. $134.8 \pm 2.9 \mathrm{mg} / \mathrm{L})$ and day $6(107.6 \pm 6.8$ vs. $68.3 \pm 2.6 \mathrm{mg} / \mathrm{L})(\mathrm{p}<0.001$ at all timepoints). CRP levels in patients with normal preoperative CRP levels reached highest mean levels on day 2 after surgery, whereas CRP levels reached highest mean levels on day 3 after surgery in patients with enhanced preoperative CRP levels (Figure 2).

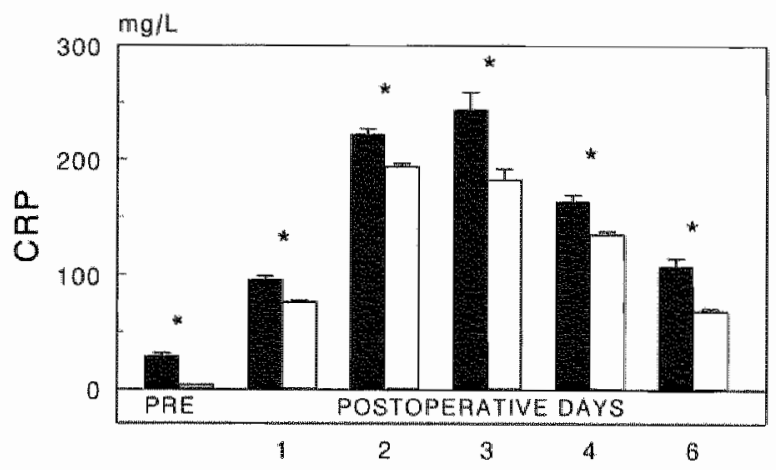

Figure 2. Mean plasma levels of C-reactive protein in cardiac surgical patients with enhanced preoperative CRP levels $>B$ $\mathrm{mg} / \mathrm{L}$, filled bars) and patients with normal preoperative CRP levels ( $\leq 8 \mathrm{mg} / \mathrm{L}$, open bars). Data are presented as mean $\pm \mathrm{SEM}$. indicates p<0.05, between groups.

The clinical characteristics of both patient groups are shown in Table 1. The incidence of postoperative infections was significantly higher in patients with enhanced preoperative CRP levels than in those with normal preoperative CRP levels, $25.3 \%$ vs. $11.2 \%$, respectively $(p<0.001)$ (Table 1 ).

The length of postoperative hospital stay was significantly longer in patients with enhanced preoperative CRP levels than in those with normal preoperative CRP levels, $10.8 \pm 1.2$ vs. $7.8 \pm 0.3$ days, $(p<0.001$ )(Table 1).

The mortality rate in patients with enhanced preoperative CRP levels $(2.7 \%)$ was not significantly different from that in patients with normal preoperative CRP levels (1.3\%)(Table 1). 
The odds ratios for possible risk factors of postoperative infections are shown in table 2. Multivariate analysis including the variables preoperative CRP ( $\leq$ or $>8 \mathrm{mg} / \mathrm{L}$ ), CPB duration ( $\leq$ or $>112$ minutes, $3^{\text {rd }}$ quartile), advanced age $\left(\leq\right.$ or $>72$ years, $3^{\text {vil }}$ quartile), sex, diabetes mellitus, and unstable angina demonstrated that a preoperatively enhanced CRP concentration was the most important independent variable predicting postoperative infection (odds ratio= $2.7 ; 95 \%$ confidence interval $=1.7$ to 4.3$)(p<0.001)($ Table 2$)$.

Table 2. Independent risk factors for postoperative intections.

\begin{tabular}{llcc}
\hline Variable & OR & $95 \% \mathrm{Cl}$ & $\mathrm{p}$ Value \\
\hline preoperative CRP $>8 \mathrm{mg} / \mathrm{L}$ & 2.68 & $1.66-4.33$ & $<0.001$ \\
$\mathrm{CPB}>112$ min. & 2.39 & $1.46-3.90$ & $<0.001$ \\
Diabetes mellitus & 2.41 & $1.27-4.58$ & $<0.01$ \\
Age $>72$ yrs. & 1.47 & $0.85-2.53$ & $\mathrm{~ns}$ \\
Female sex & 1.44 & $0.89-2.32$ & $\mathrm{~ns}$ \\
Unstable angina & 0.92 & $0.27-3.18$ & $\mathrm{~ns}$ \\
\hline
\end{tabular}

C., confidence interval. CPB, cardiopulmonary bypass. CAP, C-reactive protein. ns, not significant. $O \mathrm{R}_{\mathrm{s}}$ odds ratio.

\section{DISCUSSION}

In the present study we demonstrated that patients with enhanced CRP levels on the day before surgery are at increased risk for postoperative infections. Our data indicate that preoperative CRP levels might be useful as a predictive marker in risk stratification for postoperative infections in patients scheduled for cardiac surgery.

Potential mechanisms of enlhanced preoperative C-reactive protein plasma levels

CRP thas a number of biological activities related to nonspecific host defense. It acts as an opsonin for bacteria, parasites and immune complexes, and can activate the classical pathway of complement [10]. Enhanced CRP levels reflect cytokine-mediated hepatic response triggered by an inflammatory stimulus. The underlying stimulus for the preoperatively enhanced CRP levels in patients in 
the present study is not known. As mentioned before, patients did not show clinical signs of inflammation, yet CRP levels were enhanced in a considerable number of patients. Recently it was shown that increased levels of CRP in adults with neutropenia preceded the clinical diagnosis of a subsequently demonstrable infection [11]. Therefore some of our patients with enthanced. CRP levels on the day before surgery might have had an unsuspected infection. It has also been shown that in patients with an acute myocardial infarction, mediators of the acute phase response (e.g. interleukin-6) are increased over a time course of 4 weeks [12]. Therefore, it can not be ruled out that in some of our patients CRP levels were enhanced as a result of a myocardial infarction in the month preceding the operation. More recently it was shown that in patients with unstable angina CRP levels are increased as a result of active atherosclerotic lesions [13]. Others showed that raised circulating concentrations of CRP are predictors of coronary events in patients with stable as well as unstable angina $[3,14]$. Therefore, in patients with coronary heart disease, enhanced CRP levels might reflect inflammation of the arteries which are associated with changes in plaque morphology, rupture, and thrombosis. Furthermore, chronic activation of immune cells has been linked to atherogenesis and/or progression of atherosclerosis [15]. Recently, we showed that inflammatory processes are activated in patients with heart failure and are directly rellated to the severity of heart failure [16]. The severity of heart failure and the stage of decompensation has also been related to CRP [17], which might explain some of the variance in our preoperative CRP data.

\section{The inflammatory response to cardiac surgery}

The inflammatory response to surgical procedures has been described in numerous studies. Remarkably, this response has been shown to be identical for all kinds of surgical procedures, including cardiac operations, joint replacement, gastric restrictive operations, various types of abdominal surgery and abdominal aortic aneurysm repair $[1,2,181$. In patients with serious trauma it was shown that the acute inflammatory response to trauma and not the severity of injury is the important determinant of outcome [19]. Until now, CRP analyses were used in the diagnosis of an infective complication only after the operation [1]. One study of a small number of patients found that preoperative plasma CRP levels are enhanced in patients who develop an infection during the postoperative course [5]. Other studies also showed that postoperative CRP levels are increased in patients who develop an infection but were unable to demonstrate a 
predictive value of preoperative CRP levels [6], possibly because of the small sample size. In the present study, however, we showed not only that preoperative CRP levels in patients who have cardiac surgery are enhanced in those patients developing an infection during the postoperative course, but also that this enhanced CRP level is the most important predictor of postoperative infective complications among "classic" risk factors of infection, including advanced age, female sex, diabetes mellitus and duration of cardiopulmonary bypass [20-22].

We suggest that the preoperative balance between proinflammatory reactions and anti-inflammatory reactions is important in determining the extent of the inflammatory response and the climical outcome after cardiac surgery. In lowrisk patients undergoing coronary artery bypass grafting markers of immune cell activation (e.g. interleukin-2) were shown to be decreased perioperatively probably as a result of reduced production [23]. In addition, both proinflammatory and anti-inflammatory cytokines are increased in response to surgical procedures [24]. The extent of the inflammatory response to surgery is not only determined by the surgical procedure, but also by intrinsic patient factors, such as genetic susceptibility and premorbid health. Our data show that patients with preoperatively enhanced CRP levels, had significantly higher CRP levels on days 1 to 4 , and day 6 after surgery ( $<<0.001$ at all timepoints). This finding indicates that preoperative CRP levels determined the increase in postoperative CRP levels. Furthermore, it is known that the ability of a cell to synthesize prointlammatory and anti-inflammatory mediators is influenced by its previous state [25]. Therefore, we suggest that in patients with preoperatively enhanced CRP levels undergoing cardiac surgery, preexisting chronically activated immune cells and/or chronic activated inflammation might result in an inadequate response to the acute release of proinflammatory mediators induced by the operation. Consequently, in the perioperative period the immune system is deregulated and these patients are at increased risk for developing infections.

In the present study we showed that preoperatively enhanced CRP levels are associated with an increased risk of postoperative infections. We retrospectively created two groups of patients based on preoperative CRP plasma levels according to the method of Tracey and colleagues [3]. Consequently, neither patient group was matched for other variables, including age and unstable angina. However, when these variables were included in a multiple regression analysis together with "normal" vs. "enhanced" preoperative CRP levels preoperatively enhanced CRP plasma concentration was found to be the most important independent variable predicting postoperative infection. 
Future studies should focus on identifying the underlying stimulus for the preoperatively enhanced CRP levels in patients who have cardiac surgery. These enhanced preoperative CRP levels might reflect subclinical disease and an enhanced pro-inflammatory state. However, whatever the underlying mechanisms, we conclude that preoperative measurement of CRP is a valuable predictive marker in risk stratification for postoperative infections in patients scheduled for cardiac surgery.

\section{REFERENCES}

1. Kragsbjerg $P$. Holmberg $H$, Vikerfors $T$. Serum concentrations of interleukin- 6 , fumor necrosis factor-alpha, and C-reactive protein in patients undergoing major surgery. Eur J Surg 1995; 161:17-22.

2. Onzato $H$, Yoshizaki $K$, Nishimoto $N$, et al. Interleukin-6 as a new indicator of inflamm matory status: detection of senum levels of interleukin-6 and C-reactive protein after surgeny, Surgery 1992;111:201-9.

3. Tracey RP, Lemaitre RN, Psaty BM, et al. Relationship of C-reactive protein to risk of cardiovascular disease in the elderly. Results from the Cardiovascular Health Study and the Rural Health Promotion Project. Arterioscler Thromb Vasc Biol 1997; 1:1121-7.

4. Miholic J, Hudec M, Muller MM, Domanig E, Wolner E. Early prediction of deep sternal wound infection after heart operations by alpha- 1 acid glycoprotein and C-reactive protein measuremenls. Ann Thorac Surg 1986;42:429-33.

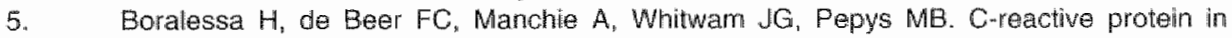
patients undergoing cardiac surgery. Anaesthesia 1986; 41:11-5.

6. Kress $H_{G}$, Gehrsitz P, Elert O. Predictive value of skin testing, neutrophil migration and $\mathrm{C}$ reactive protein for postoperative infections in cardiopulmonary bypass patients. Acta Anaesthesiol Scand 1987;31: 397-404.

7. Kollef $\mathrm{MHH}$, Sharpless L, Vlasnik J. Pasque $\mathrm{C}$. Murphy $\mathrm{D}$, Fraser V.J. The impact of noso. comial infections on patient outcomes following cardiac surgery. Chest 1997; 112:666-75.

8. Weerwind PW, Maessen JG, van Tits LJH, et al. Influence of Duraflo II heparin-treated extracorporeal circuits on the systemio inflammatory response in palients having coronary bypass. I Thorac Cardiovasc Surg 1995:110:1633-41.

9. Garnei $J S$, Jarwis WR. Emori TG. Horan TC. Hughes M M. CDC detinitions for nosocomiat infections, 1988. Am J infect Control 1988:16:128-40.

10. Sleel DM, Whitehead AS. The major acute phase reactants: C-reactive protein, serum amyloid Pi component and serum amyloid A protein. Immunol Today 1994;15:81-8.

11. Manian FA. A prospective study of dally measurement of C-reactive proiein in serum of adults with neutropenia. Clin infect Dis 1995:21: 114-21.

12. Myao $Y$, Yasue $H$, Ogawa $H$, et al. Elevated plasma interleukin-6 lovels in patients with acule myocardial infarction. Am Heert J 1993; 126:1299-304.

13. Liuzzo G, Biasueci LM, Gallimore JR, et al. The prognostic value of C-reactive protein and serum amyloid A protein in severe unstable angina. N Engl J Med 1994:331:417.24.

14. Haverkate F. Thompson SG. Pyke SD, Qalimore JR, Fepys MB. Production of Cureactive protein and risk of coronary events in stable and unstable angina. Lancet 1997;349:462-6.

15. Weiss $G$, Willeit $J$, Kiechl $S$, et al. Increased concentrations of neopterin in carotid atherasclerosis. Atherosclerosis 1994:106:263-71.

16. Fransen EJ, Maessen JG, Dentener MA, Gorgels APM. Buuman WA. Serum soluble TNF receptor as a risk factor in palients with heart failure. IMof Cell Cardiol 1996:28:A69. 
17. Pye M, Rae AP, Cobbe SM. Study of serum C-reactive protein concentration in cardiac failure. Br Heart J 1990;63:228-30.

18. Froon AHM, Greve JWM, van der Linden CJ. Increased concentrations of cytokines and adhesion molecules in patients after repair of abdominal aortic aneurysm. Eur $J$ Surg 1996:162:287.96.

19. Gosling $P$; Dickson $G R$. Serum C-reactive protein in patients with serious trauma. Injury $1992 ; 23: 483-6$.

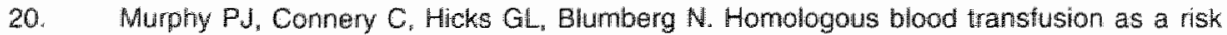
factor for postoperative infection after coronary artery bypass graft operations. I Thorac Cardiovasc Surg 1992; 104: 1092-9.

21. Rebollo MH. Bernal JM, Llorca J, Rabasa JM. Revuelta JM. Nosocomial infections in patients having cardiowascular operations: a multiwariate analysis of risk. I Thorac Cardiovase Surg 1996;112:908-13.

22. Miholic $\sqrt{ }$, Hudec $M$, Domanig $E$, ef all. Fisk factors for severe bacterial infections after valve replacement and aortocoronary bypass operations: analysis of 246 cases by logistic regression. Ann Thorac Surg 1985;40: 224-8.

23. Deng MC, Wiedner M. Erren M, Möllhoff $T$, Assmann $G$, Scheld HH. Arterial and venous cytokine response to cardiopulmonary bypass for low risk $\mathrm{CABG}$ and relation to hemodynamics. Eur J Cardiothorac Surg 1995;9:22-9.

24. Wan $S$, Marchant A, DeSmet J.M. et al. Human cytokine response lo carcliac transplantation and coronary artery bypass grafting. I Thorac Cardiovasc Surg 1996; 111:469. 77 .

25. Szabo G, Kodys K, Miller-Graziano CL. Elevated monocyte interleukin-6 (IL-6) production in immunosuppressed trauma patients. I. Fole of FcgRl crossmlinking stimulation. \& Clin Immunol 1991;11:326-35. 


\section{CHAPTER}

\section{GENERAL DISCUSSION}

All patients undergoing cardiac surgery show a systemic inflammatory response with sepsis-like symptoms during postoperative recovery $[1,2]$. Significant morbidity is rare, but when severe organ failure occurs, mortality is high [3].

At present, CPB related factors are considered the main cause of this inflammatory response. Factors that have been assumed to lead to this systemic inflammatory response, include contact activation, ischemia-reperfusion injury, hemodilution, protamine-heparin complexes, and endotoxins released from the temporary ischemic intestine [4-7]. Among these factors, complement activation resulting from the contact of blood with foreign surfaces and the subsequent activation of leukocytes and their sequestration into target organs is considered the major cause of capillary leakage and organ dysfunction [8-10].

In this thesis, a series of studies was performed to obtain more insight in factors that are associated with the release of inflammatory mediators in cardiac surgery. The studies described in this thesis comprise important new findings. First, the systemic inflammatory response to cardiac surgery is predominantly caused by the surgical procedure, and not predominantly by the cardiopulmonary bypass and aortic cross-clamping procedure per se. Second, surgery and CPB independent factors during the course of the operation affect the release of inflammatory mediators in response to cardiac surgery. Third, a preoperatively enhanced proinflammatory state in patients scheduled for cardiac surgery, is not only a determinant factor for the systemic inflammatory response to cardiac surgery, but is also associated with postoperative morbidity.

It is known that major (intra-operative) trauma leads to systemic complement actiwation, and subsequent systemic inflammation |11]. Furthermore, other types of surgical procedures without the involvement of extracorporeal circulation also have been associated with a systemic inflammatory response $[12-14 \mid$. Until now, the impact of the surgical trauma on the systemic inflammatory response in cardiac surgery patients, however, has not been paid much attention to. 
Recently, coronary artery bypass grafting on a beating heart without the use of CPB has become a new standard in patients with anterior descending and/or right coronary artery disease, who cannot be treated by coronary angioplasty [15]. In our studies (Chapters $2,4 \& 5$ ), we compared the release of inflammatory mediators and markers of myocardial tissue damage in $C A B G$ patients operated on either with $C P B$ or without $C P B$. All patients were operated on through median stemotomy resulting in similar surgical trauma for both groups, which enabled us to study the impact of the CPB procedure and associated factors (including hypothermic cardioplegia and heparin-protamine reversal) on the inflammatory response in these patients. Although CPB patients (Chapter 2) showed a significantly higher PMN response, a similar systemic inflammatory response was found in both groups. The difference in PMN response becomes evident if one takes into consideration that in CPB patients the PMN are mechanically activated as soon as the blood enters into the machine. It is important to note, however, that this activation apparantly does not stimulate the systemic inflammatory response. Evidence is thus provided that the well-known cytokine profiles found in cardiac surgery patients do not predominantly result from the CPB procedure. Furthermore, these data suggest that further improvements to the biocompatibility of the extracorporeal circuit will not be reflected by a reduced systemic inflammatory response. Of course, the evidence for this claim would be greatly substantiated if an alternative source for changes in perioperative cytokine levels could be identified.

Blood transfusions are known to have immunoreactive properties [16]. Heddle and colleagues showed that bioreactive substances in the plasma supernatant of blood products cause febrile reactions [17]. As a possible CPB independent factor affecting the release of inflammatory mediators during cardiac surgery, we studied the administration of routinely used packed red cells. We measured inflammatory mediators in patients as well as in packed red cells units. Our data show (Chapter 3) that intra-operatively transfused units of packed red cells do affect the perioperative release of inflammatory mediators in cardiac surgical patients by both enhancing part of the response, and by direct transfusion of bioreactive substances into the circulation. Thus, in patients receiving allo-geneic packed red cells, bioreactive substances might serve as a second inflam-matory insult, which amplifies the initial inflammatory response. Our data implicate that the findings of previous studies on the release of inflammatory mediators in response to cardiac 
surgery and/or the cardiopulmonary bypass procedure that did not take the intra operative administration of packed red cells transfusions into account need to be reconsidered.

Furthermore, since packed red cells were found to contain considerable amounts of BPI (Chapter 3), other neutrophil granule proteins, such as elastase, and highly toxic defensins, may also be present in transfusion products. Although the design of the study was not aimed at demonstrating a direct link between intra-operative packed red cells transfusion (bioreactive substances) and increased postoperative morbidity, intra-operative transfusions coincided with increased postoperative morbidity. Recent studies showed that blood transfusions in cardiac surgery substantially affect postoperative morbidity [18]. Therefore, future studies should reveal whether the administration of these bioreactive substances through blood transfusions directly affects postoperative morbidity.

Since experimental models of ischemic myocardial injury and observations in patients with myocardial infarction indicate that ischemic myocardial damage is associated with inflammation [19-22], we examined the association between myocardial tissue injury and systemic inflammation in CABG patients (Chapter 4 and 5). In such patients there are two possible causes of myocardial injury, (1) global ischemic myocardial injury during aortic cross-clamping and subsequent reperfusion, and (2) postoperative MI. The release of enzymes and cardiac marker proteins in our patients illustrated that myocardial ischemia-reperfusion injury resulting from the CPB and/or aortic cross-clamping procedure can be estimated early after reperfusion. Importantly, we showed that by using FABP, such injury can be separated from myocardial tissue injury due to postoperative MI. In addition, with FABP measurements, a postoperative MI can be diagnosed earlier which could improve postoperative treatment of cardiac surgical patients. For this, however, threshold levels for FABP for an appropriate diagnosis of postoperative MI after cardiac surgery have yet to be established. A possible drawback for the routine use of FABP as a diagnostic marker for postoperative $\mathrm{MI}$ in cardiac surgical patients may be that in patients with severe renal failure (e.g. acute tubular necrosis), FABP measurements could lead to false conclusions [23].

The markers of intra-operative global myocardial injury used in Chapter 4 , were correlated with inflammatory mediators. Our data showed (Chapter 5) that, although experimental studies on myocardial ischemia-reperfusion injury suggest that myocardial ischemia and reperfusion is associated with inflammation, 
these experimental findings are hard to substantiate in the cardiac surgical clinical setting (Chapter 5). Possibly the ischemic period in our CPB patients was not sufficient to elicit a considerable amount of ischemia-reperfusion induced injury. Alternatively, the release of inflammatory mediators as a result of perioperative myocardial injury may be obscured by subsequent rellease of these markers resulting from the intra-operative trauma.

Nowadays, atherosclerosis and coronary artery disease are thought to be chronic inflammatory diseases [24-25]. From our studies (Chapters 6 and 7) it appears that the inflammation underlying these disease states is of importance in case patients suffering from these diseases undergo cardiac surgery. We retrospectively analyzed the impact of a preoperative enhanced proinflammatory state on the perioperative release of inflammatory mediators, and on postoperative performance. It was shown that preoperative enhanced STNF-receptor and CRP levels in plasma of patients undergoing cardiac surgery were associated with worse postoperative performance, and a higher incidence of postoperative infections. Therefore, the measurement of these mediators preoperatively may reveal useful as prognostic indicators of clinical outcome in patients undergoing cardiac surgery. This was demonstrated in Chapter 7, where we used a patient group of 593 patients and found highly significant correlations between preoperatively enhanced CRP plasma levels and the incidence of postoperative infections. Importantly, preoperatively enhanced CRP plasma levels were even found to be stronger predictors of postoperative infections than "classic" risk factors for these infections. Consequently, we believe that CRP measurements should be implemented in preoperative risk stratification in all patients scheduled for cardiac surgery.

Appropiate threshold levels for preoperative STNF-receptor and CRP levels, however, have yet to be established. Meanwhile, the exact mechanism of sTNF-receptor release prior to, and in response to, cardiac surgery should be studied, since these receptors uniquely correlated with postoperative performance. Subsequently, in the future, patients who preope-ratively show an increased pro-inflammatory state, as reflected by elevated sTNFreceptors, might be selected for treatment with anti-inflammatory agents. The efficacy of anti-inflammatory agents has already been examined in the cardiac surgical setting, but has not been proven to be effective. However, our data suggest that patients with an already activated pro-inflammatory state may benefit from these agents. In these patients, cytokine plasma levels 
may be increased as a result of (a) the mechanisms involved in the underlying coronary artery disease, and/or (b) an active infection, or (c) idiopathic factors. If such patients are scheduled for non-emergency cardiac surgery, proper antiinflammatory treatment may be applied and surgery postponed in order to reduce the risk of postoperative complications. If these patients, however, undergo emergency surgery, the activated pro-inflammatory state might add to the increased risk of this category of patients. Another group of patients that deserves special attention in future research, is the group of patients that we have called "high-responders". These patients have "normal" preoperative plasma levels of inflammatory mediators, but show an excessive inflammatory response to an inflammatory stimulus (e.g. cardiac surgery). Future research should be aimed at developing tools to identify such patients.

In conclusion, the release of inflammatory mediators in response to cardiac surgery is predominantly induced by the surgical procedure. The extent of perioperative inflammatory mediator release is also affected by the preoperative inflammatory state of the individual patient and is associated with the incidence of postoperative complications.

\section{REFERENCES}

1. Westaby S. Organ dysfunction after cardiopulmonary bypass. A systemic inflammationy reaction by the extraconporeal circuit. Intensive Care Med 1987;13:89-95.

2. Butler 1 . Rocker GM, Westaby S. Inflammatory response to cardiopulmonary bypass. Ann Thorac Surg 1993:55:552-9.

3. Messent M, Sullwan $K_{n}$ Keogh BF, Morgan CJ, Evans. TW. Adult respiratomy distress syndrome following cardiopumonary bypass: incidence and prediction. Anatsithesia 1992 . $4.7 .267-8$.

Gillinow AM, Bator JM, Zehr Ka, al. Neutrophil adhesion mollecule expression during

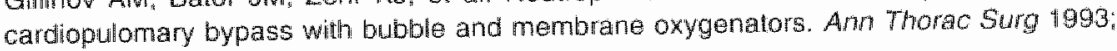
$56: 847 \times 53$

5. Weboum $C R$, Goldman $G$. Paterson 1S. Valeri CA. Shopro D. Hechman HB. Patho physiology of ischaemia-repenfusion injury: central role of the neutrophil. Br J Surg 1991 ; $78: 651-5$.

6. Andersen LW, Baek L. Degn H, Lend $I_{n}$ Krasnik M. Rasmussen JP. Presence of circum lating endotoxins during cardiac operations. J Thorac Cardiovasc Sung 1987;93:115.9.

7. Kirklin JK, Blackstone EH, Kirklin JW. Cardiopulmonary bypass: Sludies on Is damaging effects. Blood Purficition 1987,5:168-78.

8.

9.

10. Fosse E, Mollnes TE. Ingvaldsen B. Complement activation during major operations with or without cardiopulmonary bypass. I Thorac Cardiovasc Surg 1987:93:860-6. Stemberg JB, Kapelanski DP, Olson UD. Weiler JM. Cytokine and complement levels in patients undergoing cardiopumonary bypass. I Thorac Cardiovasc Surg 1993;106:1008. 16. Harlan.JM. Neutrophil-mediated vascular injury. Acta Med Scand ISuppl] 1987:715:123-9. 
11. Molnes TE. Fosse E. The complement systemi in trauma-related and ischemic uissiue damage a briat revew Shock 1994:2:301-10.

12. Froon AHM, Greve JWM, van der Linden CW. Increased concentrations of cytokines and adheston molecules in patients after repair of abdominal aortic aneurysm. Eur $J$ Surg $1996 ; 162: 287-96$

13. Kaggbjerg $P$. Holmberg $H_{3}$ Whertors T. Serum concentrations of interleukin-6, tumour mecrosis factor-alloha, and C-reactive protein in patients undergoing major operations. Eur J Surg 1995; $161: 17 \cdot 22$

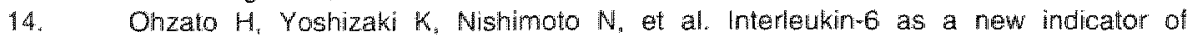
inllammatory status: detection of serum levels of intierteukin-6 and C-reactive protein atter surgery. Surgory 1992:111:201-9.

15. Westaby $\mathrm{S}$. Coronary surgery without cardiopulmonary bypass. Br Heant $J 1995 ; 73$. 2033

16. Wheatley $T$. Vitch PS. Eifect of blood transtusion on postoperative immunocompetence. Br J Anaesth 1997:78:489-92

17. Heddle NW, Klama L, Singer J ef al. The role of plasma from platelet concentrates ir transfusion reactions. N Engl Med 1994,331:625-8.

18. wan de Watering $L$ MG. Hemams J, Houbiers JGA, et all. Beneficial effects of leukocyte depition of transtused blood on postoperative complications in patients undergoing cardiac surgery. A randomized clinical study. Girculation 1998;97:562-8.

19. Hawkins $H K$, Entman ML, Zhu JY, et al. Acute inflammatory reaction after myocardial ischemic injury and repertusion. Development and use of a neutrophil-specitic ant:body. Am I Palnol 1996; 148:1957-69.

20. Engelman DT. Walanabe Maulik $\mathrm{N}_{\text {, }}$ et al. L-arginine reduces endothelial inflammafion and myocardial stunning during ischemia/reperfusion. Ann Thorac Surg 1995;60: $1275-81$.

21. Entman ML. Michael $L$. Rossen FD, et al. Intlammation in the course of early myocardial ischemia. Faseb of 1991;5:2529-37.

22. Pannitteri G, Manino B, Campa PP, Martucci $R$, Testa U, Peschle $C$. Interleukins 6 and 8 as mediators of acute phase response in acute myocardial infarction. Am J Cardiol $1997: 80: 622 \cdot 5$.

23. Görski J, Hermens WT, Barawski J, Mysliwiec M, Glatz JFC. Increased fatty acidbinding protein concentration in plasma of patients with chronic renal failure. Clin Chem 1997; $43: 193 \% 5$.

24. Crea F. Biasucci LM, Buffon A et all. Role of intlammation in the pathogenesis of unstable coronary antery disease. Am J Cardol 1997; 80:10e-16e

25. Tracey AP, Lemaitre $\mathrm{AN}$, Psaty BM, et al. Aelationship of C-reactive protein to risk of cardiowascular disedse the eldem. Results from the Cardiovascular Health Study and the Rural Health Promolion Project. Arterioscler Thromb Vasc Bio 1997; 17:1121. 7 .

26. Muehroke DD, MCCanthy PM, Kotke Marchant K, el al. Biocompatbility of heparincoated extracompoteal bypass circuits: a randomized, masked clinical trall. J Thorac Cardiovase Surg 1996; 112:442-83

27. Boonstra PW, Gu $V^{\prime} J$, Akkeman $C_{n}$ Haan w. Huzen $\mathbb{R}$, van Oeveren W. Heparin coathng of an extracomoreal circuit partly improves hemostasis after cardiopulmonary bypass. J Thorac Cardiovase Surg 1994:107:289-92 


\section{CHAPTER}

\section{SUMMARY}

Despite the normal convalescence of the vast majority of patients undergoing cardiac operations, all patients develop a non-infectious, self-limiting, systemic inflammatory response during and after surgery. Clinically, this response is associated with fever, fluid shifts, bleeding, hemodynamic instability, and, in severe cases, organ dysfunction. During the last ten years, new immunochemical assays for detection and quantification of the inflammatory products that are involved in this response have been developed. As a result, numerous studies have detailed the presence and time course of inflammatory mediators in plasma as they are released in response to cardiac surgery. In the vast majority of these studies, the extracorporeal circuit was assumed to be the major initiator of the release of these inflammatory mediators. Subsequently, plasma levels of inflammatory mediators were used to reflect the biocompatibilty of the extracorporeal circuit.

However, findings on the release of inflammatory mediators and alterations made to the extracorporeal circuit to reduce this release, were inconsistent, thus suggesting that CPB unrelated factors might play a role as well. Furthermore, the association of inflammatory mediators and clinical parameters has not been studied extensively yet. Therefore, the clinical significance of inflammatory mediator release is unknown. More insight into the mechanisms that lead to inflammatory mediator release in response to cardiac surgery, however, may help to further clarify their role in postoperative morbidity. To this end, a series of studies was performed in which we analyzed CPB independent factors that might be associated with the systemic inflammatory response to cardiac surgery. Furthermore, we studied the clinical significance of inflammatory mediator release.

The release of cytokines and other inflammatory mediators inlo plasma has been observed in all kinds of surgical patients, which indicates that the surgical procedure plays a dominant role in the systemic inflammatory response. During the last years, some CABG patients are operated on without the use of CPB (nonCBP). This enabled us to study the surgical procedure as causative factor in the systemic inflammatory response in CABG patients (Chapter 2). 
In this study evidence was provided that the acute phase response found in $\mathrm{CABG}$ patients is mainly triggered by the surgical procedure and not by the CPB procedure per se, which to our knowledge had not been shown before in this setting. However, the CPB procedure was found to additionally initiate early PMN activation.

Another factor that may affect the release of inflammatory mediators to cardiac surgery is the administration of routinely used allogeneic blood transfusions during cardiac surgery. Since others showed that non-identified bioreactive substances in the plasma supernatant produced or released by platelet products mediate reactions upon transfusion, we examined whether the perioperative administration of packed red cells affects the release of inflammatory mediators into plasma in patients undergoing cardiac surgery (Chapter 3).

For this, we examined allogeneic packed red cells units for the presence of inflammatory mediators, and measured the same mediators in the plasma of patients. This study showed for the first time that intra-operatively transfused units of packed red cells affect the perioperative release of inflammatory mediators in cardiac surgical patients. These transfusions affect the systemic inflammatory response to cardiac surgery both by enhancing part of the response, and by direct transfusion of bioreactive substances into the circulation.

Experimental models of ischemic myocardial injury and observations in patients with myocardial infarction indicate that ischemic myocardial damage is associated with inflammation. Therefore, the association between ischemic myocardial injury, as occurring in $\mathrm{CABG}$ patients operated on with CPB and aortic cross-clamping, and the release of inflammatory mediators in these patients was examined (Chapters 4 and 5 ).

First, enzymes and cardiac proteins were tested for their ability to detect global myocardial tissue injury resulting from the CPB and aortic crossclamp procedures, and their ability to separate such injury from myocardial injury due to a postoperative infarction. This study introduced the use of cardiac marker protein FABP in the cardiac surgical setting. Although FABP retrospectively enabled earlier diagnosis of postoperative myocardial infarction compared to other traditionally used markers, intra-operative global 
myocardial injury could be diagnosed equally well using any of the plasma markers studied at 0.5 hours after start of reperfusion.

Thus, enzyme or cardiac marker proteins plasma levels at 0.5 hours after start of reperfusion can be used as a tool to estimate intra-operative global myocardial injury. In Chapter 5, evidence was provided that in low-risk CABG patients, perioperative myocardial tissue injury is not significantly associated to the systemic inflammatory response found in these patients. Patients operated on with the use CPB showed significantly higher plasma levels of markers of perioperative myocardial tissue injury early after the start of reperfusion compared to nonCPB patients. Yet, the release of inflammatory mediators was similar in both patient groups. In addition, no correlations were found of markers of perioperative myocardial tissue injury (CK, CK-MB, FABP, and myoglobin) with either early neutrophil activation (BPI) or acute phase reactants (IL-6 and LBP). Therefore, although experimental studies on myocardial ischemiareperfusion injury, using isolated animal hearts, suggest that myocardial ischemia and reperfusion is associated with inflammation, these experimental findings are hard to substantiate in the cardiac surgical clinical setting.

Besides being increased in response to surgery, inflammatory mediators lave been reported to be increased in candidates for cardiac surgery. If such patients undergo cardiac surgery, preoperatively increased plasma levels of inflammatory mediators may present a risk factor since the CABG procedure per se triggers inflammation, and might enhance the ongoing inflammatory processes. Therefore, we examined the role of preoperatively increased intlammatory mediator levels in the systemic inflammatory response to cardiac surgery (Chapter 6).

This study showed that, unlike other inflammatory mediators, preoperative sTNF-receptor levels in patients scheduled for coronary artery bypass grafting represent a strong independent risk factor for postoperative complications. More importantly, among "classic" risk factors, preoperative sTNF-receptors were the most important independent variables predicting postoperative performance. Additionally, this study showed that preoperative levels of all inflammatory mediators measured ( 1 L-6, STNF-R55, sTNF-R75, sICAM-1, and sE-selectin) correlated significantly with postoperative inflammatory mediator levels.

Recently, enhanced plasma levels of the acute phase reactant CRP have been demonstrated in cardiovascular disease patients. Because these patients are 
potential candidates for cardiac surgery, some patients will be operated with preoperatively enhanced CRP levels. Since postoperatively enhanced CRP levels in cardiac surgical patients have been shown to correlate with the incidence of infections, we examined whether there is a relationship between pre-operatively enhanced CRP levels and the occurrence of postoperative infections after cardiac surgery (Chapter 7).

In this study we demonstrated that preoperatively enhanced CRP levels are associated with an increased risk of postoperative infections. Moreover, among classic risk factors for postoperative morbidity, preoperative CRP was the most important independent variable predicting postoperative infection. 


\section{SAMENVATTING}

Patiënten die een hartoperatie ondergaan vertonen een niet-infectieuze ontstekingsreactie in het gehele lichaam. Over het algemeen wordt aangenomen dat deze algehele ontstekingsreactie het gevolg is van bloedcontact met lichaamsvreemde materialen van de hart-long machine die tijdens de meeste hartoperaties wordt gebruikt. De reactie wordt gekenmerkt door de produktie van biologisch actieve stoffen die vervolgens vrijkomen in de lichaamscirculatie. De concentraties van deze biologisch actieve stoffen in het bloed worden veelal gebruikt om een indruk te krijgen van de omvang van de algehele ontstekingsreactie. Aangezien een overmatige algehele ontstekingsreactie na een hartoperatie gepaard gaat met een verhoogde morbiditeit, zou een beter inzicht in de factoren die leiden tot deze reactie kunnen bijdragen aan een vermindering van complicaties tijdens het herstel volgend op de operatie.

Een groep hormoonachtige stoffen die veelvuldig bestudeerd is in dit verband zijn de zogenaamde cytokinen. Cytokinen zijn boodschapper moleculen die, naar algemeen wordt aangenomen, een centrale rol spelen in ontstekingsprocessen. Onderzoek naar cytokinen in het bloed van patiènten die een andere operatie dan een hartoperatie ondergaan waarbij ook geen gebruik wordt gemaakt van een hart-long machine, toont aan dat deze patiënten mogelijk een zelfde algehele ontstekingsreactie vertonen als de patiënten die een hartoperatie ondergaan. Aldus rijst het vermoeden dat het chirurgisch trauma in hoge mate bijdraagt aan de algehele ontstekingsreactie bij chirurgische patiënten. De bijdrage van het chirurgisch trauma aan de algehele ontstekingsreactie in hartchirurgische patiënten was tot voor kort niet bekend.

Het doel van de studies beschreven in dit proefschrift was het identificeren van factoren, anders dan samenhangend met de hart-long machine, die betrokken zijn bij de algehele ontstekingsreactie bij patienten die een hartoperatie ondergaan.

In hoofdstuk 2 hebben we de concentraties van cytokinen bestudeerd in het bloed van patiënten die een bypass operatie van de kransslagaders ondergingen, hetzij met, hetzij zonder har-long machine. De operatie zonder hart-long machine wordt tegenwoordig uitgevoerd bij een selecte groep patiënten. De resultaten tonen dat een deel van de algehele ontstekingsreactie voomamelijk veroorzaakt wordt door de chirurgische ingreep op zich, en niet door de hartlong machine en/of daarmee samenhangende procedures.

In hoofdstuk 3 werd het effect van bloedtransfusies tijdens hartoperaties bestudeerd. Normaliter veroorzaken bloedtransfusies een afweerreactie van de 
ontvanger tegen de vreemde stoffen in het transfusiebloed. Dit gaat gepaard met een ontstekingsreactie, en aldus zouden bloedtransfusies tijdens hartoperaties de algehele ontstekingsreactie als gevolg van de operatie kunnen beïnvloeden. Wij toonden aan dat bloedtransfusies tijdens hartoperaties de algehele ontstekingsreactie op twee manieren beinvloeden. Ten eerste, direct door toediening van bioactieve stoffen in het transfusiebloed, waardoor de bloedspiegels van deze stoffen in de circulatie van de ontvanger toenemen boven op de toename als gevolg van de chirurgische ingreep. Ten tweede, door een verhoogde reactie van de patiënt mogelijk op lichaamsvreemde cellen van het transfusiebloed.

Tijdens een hartoperatie met gebruik van een hart-long machine, wordt het hart enige tijd stilgelegd om de chirurg in staat te stellen de omleidingen op de kransslagaderen te hechten. Dit heeft echter enige schade aan de hartspier tot gevolg. In hoofdstuk 4 beschrijven we dat deze schade kort nadat de circulatie van de hartspier weer op gang is gebracht geschat kan worden, en kan worden onderscheiden van schade aan de hartspier als gevolg van een hartinfarct na de operatie. Hiervoor gebruikten we enzymen en merker eiwitten afkomstig uit de hartspier die na schade aan de hartspier in de circulatie van de patiënt komen en aldus gemeten kunnen worden.

De schade aan de hartspier zoals beschreven in hoofdstuk 4 , wordt in experimentele studies in verband gebracht met een ontstekingsreactie, en aldus zou deze schade de algehele ontstekingsreactie als gevolg van de operatie kunnen beinvloeden. Dit werd in hoofdstuk 5 onderzocht door de onderlinge afhankelijkheid van merkers van hartspierschade en merkers van ontsteking te bestuderen. Hier wordt beschreven dat in patiënten die een hartoperatie ondergaan, de hartspierschade als gevolg van de hart-long machine en het tijdelijk stilleggen van het hart, niet meetbaar bijdraagt aan de algehele ontstekingsreactie in deze patiënten.

In de hoofdstukken 6 en 7 werd de invloed bestucleerd van een verhoogde ontstekingsactiviteit vóór de operatie op de algehele ontstekingsreactie na de operatie. In hoofdstuk 6 werden 5 cytokinen in het bloed van de patiënten bestudeerd. De bloedspiegels van deze stoffen voorafgaande aan de operatie bepaalden in hoge mate de toename in bloedspiegels als gevolg van de operatie. Verhoogde bloedspiegels van één van deze stoffen (sTNF-receptoren) bleken verband te houden met een verhoogde kans op complicaties tijdens de herstelperiode.

Het belang van reeds voorafgaande aan de operatie verhoogde bloedspiegels van stoffen die betrokken zijn bij de algehele ontstekingsreactie 
wordt onderstreept in hoofdstuk 7. Hier tonen we dat een verhoogde bloedspiegel van het eiwit CRP voorafgaande aan de operatie, een verhoogde kans op een infectie na de operatie voorspelt. Hoofdstuk 6 en 7 tonen aan dat de omvang van de algehele ontstekingsreactie als reactie op de chirurgische ingreep voorspeldt kan worden door de bepaling van bepaalde ontstekingsmerkers voorafgaande aan de operatie. Aldus zouden deze bepalingen kunnen leiden tot een betere risicoanalyse voor complicaties na de operatie. 


\section{DANKWOORD}

Toen ik op l januari 1994 als part-time onderzoeksmedewerker in dienst trad bij de afdeling Cardiopulmonale Chirurgie van het academisch ziekenhuis Maastricht, kon ik alleen maar hopen dat het uiteindelijk zou resulteren in het yoor u liggend proefschrift. Gedurende de afgelopen 5 jaar zijn vele mensen betrokken geweest bij de studies die in dit proefschrift beschreven zijn. In de hoop niemand te vergeten wil ik een aantal mensen met name noemen.

Allereerst mijn co-promotor dr. Jos Maessen. Jos, jouw onuitputtelijke energie en interesse voor alles wat maar enigszins verwant is met onderzoek, was voor mij gedurende de afgelopen jaren een belangrijke drijfveer. Ik ben er dan ook trots op om jouw eerste promovendus te zijn. In klinisch onderzoek Jeiden antwoorden vaak tot een evenredig aantal nieuwe vragen. Bij de studies uit de onderzoekslijn die in dit proefschrift staan was dit eveneens het geval. Ik hoop dat we de komende jaren nog een aantal van deze vragen zullen oplossen.

Mijn co-promotor dr. Wim Buurman. Wim, jouw vermogen om schijnbaar grote problemen in enkele woorden samen te vatten leidde telkenmale tot een heldere lijn in de verschillende verhalen. Mede gezien de reacties in het buitenland ben ik er trots op dat wij voor onze cytokine bepalingen bij jouw lab terecht konden (kunnen!).

Mijn promotor, prof. dr. Mat Daemen. Mat, ik wil je bedanken voor je kritische blik op het manuscript hetgeen resulteerde in een heldere opbouw van het proefschrift, en een beperking tot relevante zaken.

Alle leden van de staf Cardiopulmonale Chirurgie (CPC). Kees, Gijs, Ted en Paul, ik dank jullie dat mij de kans geboden werd om de onderzoeken die ik cle afgelopen jaren bij de afdeling CPC heb uitgevoerd af te ronden met dit proefschrift.

Alle secretaresses van de staf Cardiopulmonale Chirurgie. Helma, Hester, Sylvia, Miriam en Anja, ik dank jullie voor de broodnodige psychische steun in het soms moerasachtige klimaat binnen het azM.

Alle (ex-)medewerkers van de afdeling Extracorporale Circulatie (ECC), Kees, Nicole, Erwin, Youri, Jan, Evelien, Monique, Suzanne, Jolanda, Patrick, Pascalle, en met name Dick de Jong. Dick, jouw expertise op perfusie gebied is wereldwijd erkend. De samenstelling van het extracorporale circuit in het azM is dankzij jouw inspanningen van dusdanig hoge kwaliteit, 
dat het voor onderzoekers wrijwel onmogelijk is geworden het mut van nieuwe biocompatibele componenten aan te tonen. Mijn complimenten.

Alle verpleegkundigen van de cardiochirurgische intensive-care (F3). Helaas kan ik jullie niet allemaal bij naam bedanken, maar ik ben jullie dankbaar voor alle bloedsamples die jullie voor mij (ons) hebben afgenomen. Th hoop dat jullie in de toekomst even enthousiast zullen reageren als in het verleden wanneer ik met een blauwe bak de afdeling betreed. Verder, wil ik ook de anesthesie verpleegkundigen en de cardio-anesthesisten bedanken voor het afnemen van bloedsamples.

Wim Hermens en Jan Glatz. Wim, onze discussies hebben diverse malen geleid tot een verhoging van de kwaliteit van mijn verhalen. Jan, ik bein er trots op dat wij FABP hebben geïntroduceerd in de cardiochirurgie.

Mieke Dentener en Nicole Senden. Mieke en Nicole, jullie waren de onmisbare schakel tussen het lab Buurman en de kliniek.

Maurice Pelsers, Marie-Louise Bouwmans, en Bernadette Kops wil ik bedanken voor hun hoogwaardige enzym- en myocardiale merkereiwit bepalingen.

Alle medewerkers van het CHEMIE 4 (Klinisch Chemisch Lab). Met name Lou Donselaar wil ik bedanken voor het feit dat hij gedurende de jaren één en ander ter plaatse heeft gecoördineerd.

De leden van de beoordelingscommissie, prof. dr. M. van Dieijen-Visser, prof. dr. L. Eijsman, prof. dr. G.J. van der Vusse, prof. dr. W. Flameng, en prof. dr. G. Kootstra als voorzitter, wil ik danken voor hun bereidheid het manuscript te willen beoordelen.

Mijn ouders. Pa en Ma, bedankt voor jullie onvoorwaardelijke steun: jullie gaven me niet alleen de mogelijkheid om te gaan studeren, maar zijn ook altijd achter me blijven staan bij mijn keuzes.

Monique, jouw nuchtere kijk op zaken heeft me regelmatig unet beide beneri op de grond gehouden. Ik hoop dat je dit nog vele jaren zult blijven doen.

Milton, jij bent het zonnetje in huis dat iedere dag opnieuw strailt! 


\section{LIST OF PUBLICATIONS}

Full papers

Glucose and insulin responses after commonly used sport feedings before and after a 1-hr training session. Hofman Z., Kuipers H., Keizer H.A., Fransen E.J., Servais R.C.J.

International Joumal of Sport Nutrition, 5:194-205, 1995.

Overtraining following intensified training with normal muscle glycogen. Snyder A.N., Kuipers H., Cheng B., Servais R., Fransen E.J.

Medicine and Science in Sports and Exercise, 27: 1063-1070, 1995.

Influence of Duraflo II heparin-treated extracorporeal circuits on the systemic inflammatory response in patients having coronary bypass. Weerwind P.W., Maessen J.G., van Tits L.J.H., Stad R.K., Fransen E.J., de Jong D.S., Penn O.C.K.M.

The Journal of Thoracic and Cardiovascular Surgery, 110: 1633-1641, 1995.

Release of LPS toxicity-modulating proteins in patients undergoing cardiopulmonary bypass using non-coated and heparin-coated extracorporeal circuits. A Clinical Pilot Study. Bouma M.G., Maessen J.G., Weerwind P.W., Dentener M.A., Fransen E.J., de Jong D.S., Buurman W.A.

Chest, 111: 577-583, 1997.

Demonstration of ischaemia-reperfusion injury separate from postoperative infarction in coronary artery bypass graft patients. Erik J. Fransen, Jos G. Maessen, Wim T. Hermens, Jan F.C. Glatz.

Amnals of Thoracic Surgery, 65: 48-53, 1998.

Systemic inflammation present in patients having CABG without extracorporeal circulation. Fransen E.J., Maessen J.G., Dentener M.A., Senden N.H.M., Geskes G.G., Buurman W.A.

Chest. 113:1290-1295, 1998.

Enhanced preoperative C-reactive protein plasma levels as a risk factor for infections after cardiac surgery. Erik J. Fransen, Jos G. Maessen, Theodoor 
W.O. Elenbaas, Egidius E.H.L. van Aarnhem, and Marja P. van Diejen-Visser. Annals of Thoracic Surgery 1999;67:139-145.

Preoperative soluble TNF-receptor levels as a risk factor in coronary artery bypass graft patients. Erik J. Fransen, Jos G. Maessen, Mieke A. Dentener, Nicole H.M. Senden, Wim A. Buurman.

submitted, 1998.

Impact of blood transfusions on inflammatory mediator release in patients undergoing cardiac surgery. Erik J. Fransen, Jos G. Maessen, Mieke A. Dentener, Nicole H.M. Senden, Wim A. Buurman.

In press, Chest

Perioperative myocardial tissue injury and the release of inflammatory mediators in coronary artery bypass graft patients. Erik J. Fransen, Jos G. Maessen, Wim T. Hermens, Jan F.C. Glatz, Mieke A. Dentener, Wim A. Buurman. submitted, 1998.

\section{ABSTRACTS}

Influence of Duraflo II heparin-treated extracorporeal circuits on the systemic inflammatory response in patients having coronary bypass. Weerwind P.W., Maessen J.G., van Tits L.J.H., Stad R.K., Fransen EJ., de Jong D.S., Penn O.C.K.M. (Winner of the "Best Paper A ward")

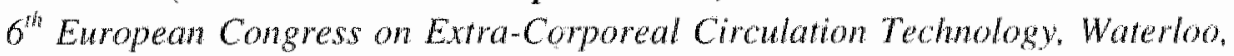
Beigium, June 7-10,1995.

Serum soluble TNF receptor levels predict postoperative cardiac performance in high-risk CABG patients. Fransen E.J., Maessen J.G., Dentener M.A., Gorgels A.P.M., Buurman W.A., Penn O.C.K.M.

Intensive Care Medicine, Volume 22, suppl. 1, 1996.

The acute phase response following cardiac surgery in patients with or without cardiopulmonary bypass. Fransen E.J., Maessen J.G., Geskes G.G., Dentener M.A., Senden N.H.M., Buurman W.A.

Cor Europaeum, European Heart Joumal of Cardac Interventions, Volume 5 , $1,1996$. 
Serum soluble TNF receptor as a risk factor in patients with heart failure. Fransen E.J., Maessen J.G., Dentener M.A., Gorgels A.P.M., Buurman W.A. Joumal of Molecular and Cellular Cardiology. Vol. 28 (5) May 1996.

The acute phase response following cardiac surgery in patients with or without cardiopulmonary bypass. Fransen E.J., Maessen I.G., Geskes G.G., Dentener M.A., Senden N.H.M., Buurman W.A.

Journal of Molecular and Cellular Cardiology, Vol. 28 (5) May 1996.

Global myocardial damage vs. postoperative infarction in CABG patients. Fransen E.J., Maessen J.G., Hermens W.T., Glatz J.F.C. Journal of Molecular and Cellular Cardiology, Vol. 28 (5) May 1996.

Global myocardial damage vs. postoperative infarction in patients having coronary bypass. Fransen E.J., Maessen J.G., Hermens W.T., Glatz J.F.C. European Heart Journal, Volume 17 Abstr. Suppl. August 1996.

The acute phase response following cardiac surgery in patients with or without cardiopulmonary bypass. Fransen E.J., Maessen J.G., Geskes G.G., Dentener M.A., Senden N.H.M., Buurman W.A.

Cardiovascular Surgery, Volume 4, Suppl. 1, 1996

Introduction of Summit as automation program on a cardiac surgical department in the Netherlands. Fransen E.J., Maessen J.G.

Annual Scientific Meeting of the Dutch Society for Thoracic Surgery, Zeist, The Netherlands, Oktober 26, 1996.

Early detection of postoperative myocardial tissue loss using plasma myoglobin and fatty acid-binding protein in patients having coronary bypass. Fransen E.J., Maessen J.G., Hermens W.T., Geskes, G.G., Glatz J.F.C. The Journal of Heart Failure, Volume 4. Number 1. May 1997.

Leukocyte depletion during cardiopulmonary bypass in adult patients. Reiters, P.H.C.M., Maessen, J.G., Fransen, E.J., de Jong, D.S. $7^{\text {th }}$ European Congress on Extra Corporeal Circulation Technology, Karlowy Vary, Crech Republic, June 11-14, 1997. 
Compartment syndrome in the lower extremity after CABG. an investigation into the cause and a presentation of clinical cases. F.A.J.M. van den Wildenberg, J.G. Maessen, R.M. van Osch, E.J. Fransen, M.W. Smets.

$4^{\text {th }}$ International Congress on Thoracic and Cardiovascular Surgery in China. Beijing. China, November 10-12, 1997.

Enhanced preoperative C-reactive protein plasma levels predict postoperative infections in patients undergoing cardiac surgery. E.J. Fransen, J.G. Maessen, Th.W.O. Elenbaas, E.E.H.L. van Aarnhem, E. Stobberingh, H. Visschers, M.P. van Dieijen-Visser.

Critical Care, Volume 2, Supplement 1, March 1998.

Myocardial dissue damage in patients undergoing $\mathrm{CABG}$ with or without cardiopulmonary bypass. Fransen E.J., Maessen J.G., Geskes, G.G.

Nederlands Tijdschrift voor Geneeskunde, 47: 2601, 1998.

Perioperative blood transfusions and inflammatory mediator release in cardiac surgery patients. E.J. Fransen, J.G. Maessen, M.A. Dentener, N.H.M. Senden, W.A. Buurman.

Intensive Care Medicine, Volume 24, Supplement 1, 1998.

Myocardial tissue damage in patients undergoing CABG with or without cardiopuimonary bypass. E.J. Fransen, J.G. Maessen, G.G. Geskes, J.F.C. Glatz, W.T. Hermens.

International Congress on Coronary Artery Disease, Volume 2, Number I, Ocrober 1998.

Enhanced preoperative C-reactive protein plasma levels as a risk lactor for postoperative infections in patients undergoing cardiac surgery. E.f. Fransen, J.G. Maessen, T.W.O. Elenbaas, M.P. van Dieijen-Visser.

International Congress on Coronary Artery Disease. Volume 2. Number I. October 1998.

Impact of perioperative allogeneic blood transfusions on the release of inflammatory mediators in patients undergoing cardiac surgery. E.l. Fransen, J.G. Maessen, M.A. Dentener, N.H.M. Senden, W.A. Buurman.

Intemational Congress on Coronary Artery Disease, Volume 2, Namber 1. October 1998. 
Myocardial tissue damage in patients undergoing $\mathrm{CABG}$ with or without cardiopulmonary bypass. E.J. Fransen, J.G. Maessen, G.G. Geskes, J.F.C. Glatz, W.T. Hermens.

Chest, Volume 114, 4S, 1998.

Impact of perioperative allogeneic blood transfusions on the release of inflammatory mediators in patients undergoing cardiac surgery. E.J. Fransen, J.G. Maessen, M.A.Dentener, N.H.M. Senden, W.A. Buurman.

(Winner of the "ACCP Young Investigator Award"). Chest, Volume 114, 4S, 1998.

Enhanced preoperative C-reactive protein plasma levels as a risk factor for postoperative infections in patients undergoing cardiac surgery. E.J. Fransen, J.G. Maessen, T.W. Elenbaas, M.P. van Dieijen-Visser.

Chest, Volume 114, 4S, 1998.

Impact of perioperative allogeneic blood transfusions on the release of inflammatory mediators in patients undergoing cardiac surgery. E.J. Fransen, J.G. Maessen.

Annual Scientific Meeting of the Dutch Society for Thoracic Surgery, Amsterdam, The Netherlands, November 29, 1998. 


\section{CURRICULUM VITAE}

Erik Fransen werd geboren op 17 februari 1968 te Boekelo (Overijssel). De middelbare schooltijd werd doorgebracht op her Jacobus College te Enschede en de Scholengemeenschap Marianum te Groenlo, waar in 1988 het VWO diploma werd behaald. In datzelfde jaar begon hij met zijn studie Gezondheidswetenschappen aan de Universiteit Maastricht (UM), met als afstudeerrichting Bewegingswetenschappen. Het doctoraalexamen werd behaald in januari 1993 na een stage bij de vakgroep Bewegingswelenschappen aan de UM. Sinds 1 januari 1994 is hij werkzaam als onderzoeksassistent bij de afdeling Cardiopulmonale Chirurgie van het Academisch Ziekenhuis Mastricht. Op 11 november 1998 ontving hij de "ACCP Young Investigator Award" op het jaarlijks congres van de American College of Chest Physicians in Toronto, Canada.

$\mathrm{H}_{1 j}$ is getrouwd met Monique Haverkort. Zij hebben één zoon, Milton. 